\title{
Solar Photovoltaic Financing: Deployment by Federal Government Agencies
}

Technical Report NREL/TP-6A2-46397 July 2009

Karlynn Cory, Charles Coggeshall, Jason Coughlin, and Claire Kreycik

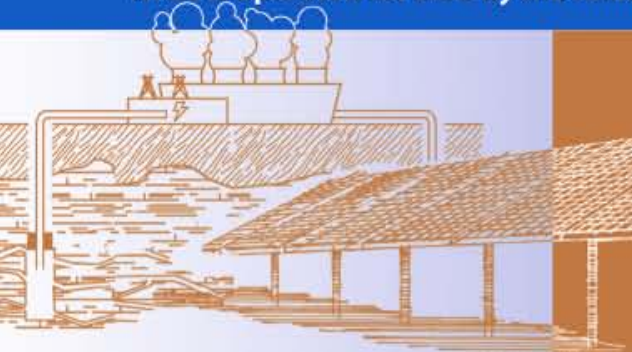




\section{Solar Photovoltaic Financing: Deployment by Federal Government Agencies}

Karlynn Cory, Charles Coggeshall, Jason Coughlin, and Claire Kreycik

Prepared under Task No. PVB9.4210

\section{Technical Report} NREL/TP-6A2-46397

July 2009

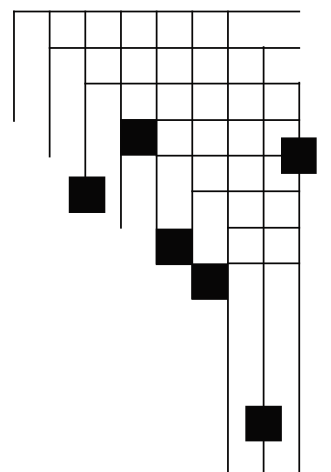

National Renewable Energy Laboratory

1617 Cole Boulevard, Golden, Colorado 80401-3393

303-275-3000 • www.nrel.gov

NREL is a national laboratory of the U.S. Department of Energy

Office of Energy Efficiency and Renewable Energy

Operated by the Alliance for Sustainable Energy, LLC

Contract No. DE-AC36-08-GO28308 


\section{NOTICE}

This report was prepared as an account of work sponsored by an agency of the United States government. Neither the United States government nor any agency thereof, nor any of their employees, makes any warranty, express or implied, or assumes any legal liability or responsibility for the accuracy, completeness, or usefulness of any information, apparatus, product, or process disclosed, or represents that its use would not infringe privately owned rights. Reference herein to any specific commercial product, process, or service by trade name, trademark, manufacturer, or otherwise does not necessarily constitute or imply its endorsement, recommendation, or favoring by the United States government or any agency thereof. The views and opinions of authors expressed herein do not necessarily state or reflect those of the United States government or any agency thereof.

Available electronically at http://www.osti.gov/bridge

Available for a processing fee to U.S. Department of Energy and its contractors, in paper, from:

U.S. Department of Energy

Office of Scientific and Technical Information

P.O. Box 62

Oak Ridge, TN 37831-0062

phone: 865.576 .8401

fax: 865.576 .5728

email: mailto:reports@adonis.osti.gov

Available for sale to the public, in paper, from:

U.S. Department of Commerce

National Technical Information Service

5285 Port Royal Road

Springfield, VA 22161

phone: 800.553.6847

fax: 703.605.6900

email: orders@ntis.fedworld.gov

online ordering: http://www.ntis.gov/ordering.htm 


\section{Acknowledgments}

This work was funded by the U.S. Department of Energy (DOE) Solar Program; therefore, the authors wish to thank participating DOE staff_-Tom Kimbis and Charles Hemmeline-for providing useful insights and overall direction to this project. The authors are also grateful for the guidance and helpful input of the project managers, Robert Margolis and Selya Price of the National Renewable Energy Laboratory (NREL). We would also like to thank the individuals who reviewed various drafts of this report, particularly Kevin DeGroat of Antares Group, Inc; Douglas Dahle, Chandra Shah, Michael Mendelsohn, and Brian Levite of NREL; and Matthew Gray of DOE. Other reviewers that provided useful insights and comments to various sections include: Robert Westby, Karen Thomas, Andy Walker, Alicen Kandt, Nate Blair, and Otto Van Geet of NREL; and Randy Manion, John Kral, and Melanie Reed of the Western Area Power Administration (WAPA). The authors also thank Jim Leyshon, Ray David, and Bryan Bechtold for providing fantastic graphics. And finally, we are deeply grateful to Lisa J. Teman of All the Right Words and Jennifer Josey of NREL for providing editorial support.

The authors would also like to thank our interviewees for their time, for reviewing our descriptions of their programs and activities in the market, and for providing additional clarifications. Thank you to representatives from the public sector for their useful input, including: New Jersey's Clean Energy Program, New Jersey Board of Public Utilities, Massachusetts Technology Collaborative, New York State Energy and Research Development Authority, Environmental Protection Agency, National Park Service, U.S. Air Force Facility Energy Center, U.S. Army, General Services Administration, U.S. Department of Energy, and Lawrence Berkeley National Laboratory. We would also like to thank the utility, Xcel Energy. 


\section{List of Acronyms}

\begin{tabular}{|c|c|}
\hline AWC & Area-wide contracts \\
\hline BETC & Business Energy Tax Credit \\
\hline CESA & Clean Energy States Alliance \\
\hline CEQ & Council on Environmental Quality \\
\hline CORE & Customer On-Site Renewable Energy Program (New Jersey) \\
\hline DESC & Defense Energy Support Center \\
\hline DG & Distributed generation \\
\hline DOD & Department of Defense \\
\hline DOE & Department of Energy \\
\hline DSIRE & Database of State Incentives for Renewables and Efficiency \\
\hline EA & Environmental assessment \\
\hline EPBB & Expected Performance-Based Buy-Down \\
\hline ECM & Energy conservation measure \\
\hline EESA 2008 & Emergency Economic Stabilization Act of 2008 \\
\hline EIS & environmental impact statement \\
\hline EISA 2007 & Energy Independence and Security Act of 2007 \\
\hline EO & Executive order \\
\hline EPA & U.S. Environmental Protection Agency \\
\hline EPAct 2005 & Energy Policy Act of 2005 \\
\hline ESA08 & Economic Stimulus Act of 2008 \\
\hline ESCO & Energy services company \\
\hline ESPC & Energy savings performance contract \\
\hline FAR & Federal Acquisition Regulations \\
\hline FEMP & Federal Energy Management Program \\
\hline FES & Firm electric service \\
\hline FONSI & Finding of no significant impact \\
\hline FRESA & Federal Renewable Energy Screening Assistant \\
\hline FY & Fiscal year \\
\hline GSA & U.S. General Services Administration \\
\hline IA & Interagency agreement \\
\hline IDIQ & Indefinite delivery indefinite quantity \\
\hline IOU & Investor-owned utility \\
\hline IPP & Independent power producer \\
\hline IRR & Internal rate of return \\
\hline IRS & Internal Revenue Service \\
\hline ITC & Investment Tax Credit \\
\hline $\mathrm{kW}$ & Kilowatt \\
\hline $\mathrm{kWh}$ & Kilowatt hour \\
\hline LCOEG & Levelized cost of electricity generation \\
\hline LEED & Leadership in Energy and Environmental Design \\
\hline LIBOR & London Interbank Offered Rate \\
\hline LSE & Load-serving entity \\
\hline MACRS & Modified Accelerated Cost-Recovery System \\
\hline
\end{tabular}




\begin{tabular}{|c|c|}
\hline MW & Megawatt \\
\hline MWh & Megawatt hour \\
\hline NDA & Non-disclosure agreement \\
\hline NEPA & National Environmental Policy Act \\
\hline NHPA & National Historic Preservation Act \\
\hline NREL & National Renewable Energy Laboratory \\
\hline NYSERDA & New York State Energy Research and Development Authority \\
\hline OPUC & Oregon Public Utilities Commission \\
\hline PEIS & Programmatic environmental impact statement \\
\hline PMA & Power marketing administration \\
\hline PPA & Power purchase agreement \\
\hline PSE\&G & Public Service Electric \& Gas \\
\hline PV & Photovoltaic \\
\hline $\mathrm{R} \& \mathrm{D}$ & Research and development \\
\hline $\mathrm{REC}$ & Renewable energy credit \\
\hline RET & Renewable-energy and energy-efficient technology \\
\hline RFP & Request for proposal \\
\hline RFQ & Request for qualifications \\
\hline RPS & Renewable portfolio standard \\
\hline $\mathrm{RReDC}$ & NREL's Renewable Resource Data Center \\
\hline $\mathrm{SACP}$ & Solar alternative compliance payment \\
\hline SAM & Solar Advisor Model \\
\hline $\mathrm{SBC}$ & System benefits charge \\
\hline SBIC & Sustainable Building Energy Council \\
\hline SEIA & Solar Energy Industry Association \\
\hline SI & Statement of interest \\
\hline SREC & Solar renewable energy credit \\
\hline SSA & Social Security Administration \\
\hline TEAM & Transformational Energy Action Management \\
\hline UESC & Utility energy service(s) contract \\
\hline USPS & U.S. Postal Service \\
\hline WAPA & Western Area Power Administration \\
\hline
\end{tabular}




\section{Executive Summary}

Opportunities for the deployment of distributed photovoltaic (PV) systems at federal government facilities in the United States are increasing significantly as a result of supportive government policies, innovative financing mechanisms, and the rapid development of the solar industry. Yet many federal agencies still lack the information and know-how to overcome the challenges associated with making on-site solar PV projects economically viable. This report examines the renewable energy and energy intensity standards and goals federal agencies must meet, assesses the array of financing structures and tools available to federal agencies to finance on-site PV projects, and analyzes the economics of federal PV projects in various locations based on locally available incentives and payments.

We describe and evaluate a diverse array of incentives and financing tools that are available to federal agency PV projects, including:

- Federal appropriations,

- State- and utility-level cash incentives,

- Revenues from renewable energy certificates (RECs) or the more-specific solar RECs (SRECs), depending on state renewable portfolio standards (RPS),

- Energy cost savings (and the use of performance contracting to help fund projects),

- Innovative financing structures in which federal agencies partner with private entities that utilize federal tax incentives and other tools to deploy on-site PV. These partnerships can take advantage of:

- Federal investment tax credits (ITCs) via a third tax-paying party,

- Federal Modified Accelerated Cost-Recovery System (MACRS), or accelerated depreciation including bonus depreciation, and

○ Federal loan guarantees. ${ }^{1}$

In addition to these approaches, federal agencies can use contracts with private entities in one of three general formats: 1) energy savings performance contract (ESPC); 2) Super ESPC (in which agencies can take advantage of general contract parameters and prequalified contractors without executing a full competitive bidding process); 3) and utility energy service contract (UESC). Although these structures mostly focused on deployment of energy efficiency (EE) measures, a few have included PV-system deployment.

New financing structures also have emerged, including the third-party ownership power purchase agreement (PPA) model. This model, either alone or in conjunction with an ESPC, provides several benefits to the federal agency. Under this structure, the government entity hosts - but does not own - a PV system. By partnering with a third-party owner, the agency does not pay anything up front and is able to secure, on average, 20-year fixed-price power for the output of the system at or below current retail rates (in the first year). Private-sector financiers own the projects so as to secure federal tax credits and, in exchange, pass on their tax credit advantage to the federal agency through lower power prices. Such public-private partnerships are expected to

\footnotetext{
${ }^{1}$ The eligibility and application process for the federal loan guarantee program must be finalized in a Guidance document to be issued by the U.S. Department of Energy.
} 
continue, as entities that pay taxes likely will be needed to secure U.S. Department of Treasury grants (a temporary option in lieu of tax credits and included in the Recovery Act).

In some cases, a contractual intermediary can help federal agencies that are unable to sign longterm power contracts (longer than 10 to 15 years). ${ }^{2}$ The Western Area Power Administration (WAPA) has the ability to sign 20-year contracts, and has offered to sign such long-term contracts for federal agencies located in its service territory, even those which are not customers of WAPA. By signing the 20-year contract with the developer, WAPA provides an important service, helping the private developer secure financing because the costs can be amortized over a longer period of time. This helps to lower the electricity price in the PPA with the federal agency.

Our analysis of market opportunities and financing structures available to federal PV projects highlights a number of key strategies and opportunities for federal energy managers:

Consider a third-party ownership PPA to take advantage of federal tax credits/grants. As federal agencies pursue PV deployment programs, the third-party ownership model (including partnering with utilities) will be a key financing structure to take advantage of an array of federal incentives like the ITC and MACRS. This model can be used as a component of an ESPC as well as a UESC, now that utilities are eligible for the ITC. ${ }^{3}$ Private partners will be most interested in this model in states with significant PV rebates or in or near a state with a solar tier in its RPS, because the rebates and SREC revenues can help complete the PV project economically (as compared to average retail electric rates). Importantly, the Recovery Act also enables taxable entities to recover the ITC in the form of a grant. Given the economic downturn and the reduction of corporate tax liabilities, the option to take the ITC in the form of a grant will broaden the applicability of this benefit.

Consider bundling PV with energy efficiency activities. In addition to helping meet federal energy intensity reduction mandates, bundling PV with EE improves the payback-cost effectiveness through the total package of activities.

Use federal and state cash incentives. Federal and state cash incentives can provide federal agencies with a significant source of capital to lower the costs of deploying PV. The Recovery Act offers appropriations to federal agencies for energy efficiency and renewable energy investment. At the state level, system benefit funds and other funds generally are available to federal agencies for deployment of PV and other renewables.

Reduce electricity bills. Federal agencies can reduce utility electricity bills by producing electricity on-site with a PV system. These savings are not guaranteed due to the uncertainty of electricity prices, and generally are not sufficient to economically justify the deployment of a PV system. However, historical data shows a consistent upward trend in annual conventional electricity prices over the past decade. Further, the Energy Information Administration (EIA) forecasts price increases over the next several years, despite the current economic downturn.

\footnotetext{
${ }^{2}$ It is important to note that as of July 2009, draft federal legislation in the U.S. House of Representatives and the U.S. Senate include a provision that would allow all federal agencies to use either 20-year or 30-year contracts (respectively) for renewable electricity procurement, according to Kevin DeGroat of Anteres group (personal e-mail communication on July 17, 2009). Readers should check to see if this legislation was passed.

${ }^{3}$ The Emergency Economic Stabilization Act of 2008 clarified that utilities are eligible to take the ITC.
} 
Finally, there is a significant likelihood a federal response to climate change will increase electric utility bills over time; thus, deployment of PV or EE should capture this greater benefit.

Benefit from the value of green attributes. Where available, SRECs offer an additional revenue stream that can be combined with incentives to offset the cost of PV deployment. The value of an SREC is greatest in states with solar tiers (or set asides) in their renewable portfolio standard requirements. In certain markets, voluntary SRECs also command a smaller-but sizable - premium. It is important to note that selling a project's SREC denies the owner the right to claim environmental benefits, including counting them toward the federal renewable energy requirements. These SRECs, however, can be replaced by the purchase of less expensive landfill gas or wind renewable energy certificates (REC) to receive full credit for the project toward federal goals and mandates.

When using an ESPC, Super ESPC, and UESC, require consideration of PV deployment. Presidential goals for increasing federal government use of renewables encourage a holistic site evaluation that considers the optimal project portfolio to both reduce fossil-fuel energy consumption and increase renewable energy generation. In turn, federal agencies are successfully using ESPCs, Super ESPCs and UESCs, to help finance EE and sometimes on-site renewables like PV.

Work with a contractual intermediary. ${ }^{4}$ For those agencies that are limited and cannot sign power-procurement contracts for the necessary period of time (generally 20 years), consider working with an intermediary in the contracting process. Those federal agencies located in WAPA's service territory should speak to WAPA authorities about potential opportunities to collaborate on solar PV projects.

Throughout this report, specific project examples explain how the different incentives, cost savings, and revenues actually are used to deploy PV in the federal sector. The examples also examine the various financing structures in greater detail. Appendix A provides an index of all the examples presented, and shows which components contribute to successful project financing of federal projects.

\footnotetext{
${ }^{4}$ It is important to note that as of July 2009, draft federal legislation in the U.S. House of Representatives and the U.S. Senate include a provision that would allow all federal agencies to use either 20-year or 30-year contracts (respectively) for renewable electricity procurement, according to Kevin DeGroat of Anteres Group (personal e-mail communication on July 17, 2009). Readers should check to see if this legislation was passed.
} 


\section{Table of Contents}

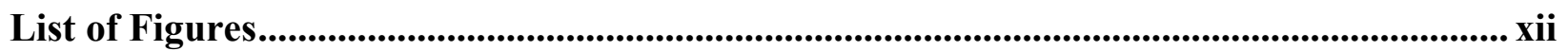

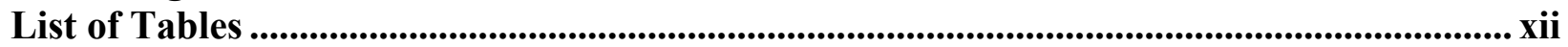

1 Federal Sector Background: Energy and Electricity Use ..................................................... 1

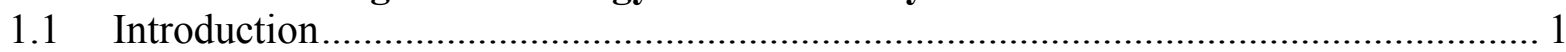

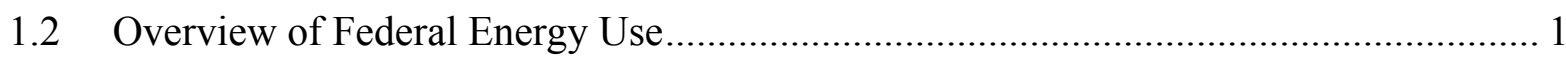

$1.3 \quad$ Federal Renewable Energy Requirements ……….................................................. 2

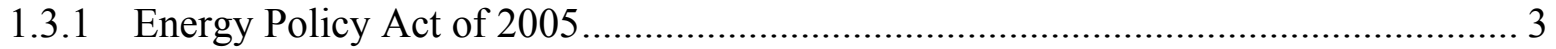

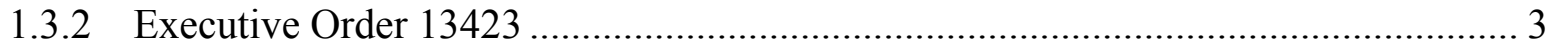

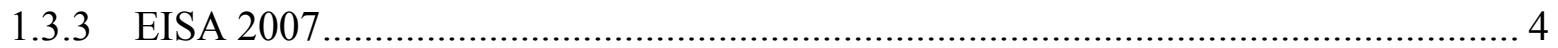

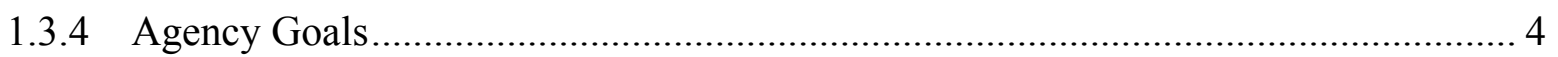

$1.4 \quad$ Federal Renewable Energy Consumption................................................................... 5

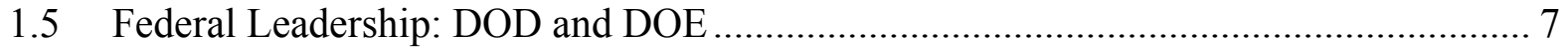

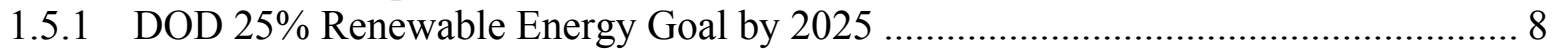

1.5.2 The DOE's Transformational Energy Action Management Initiative......................... 8

1.6 Barriers to PV Deployment in the Federal Government.............................................. 9

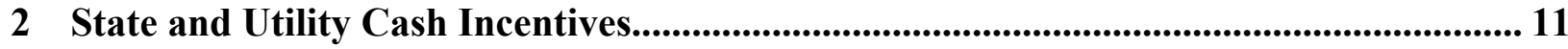

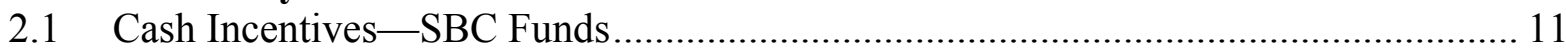

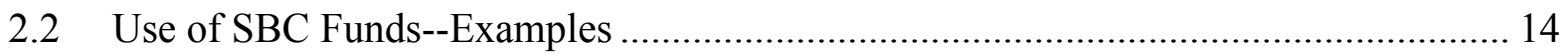

2.2.1 State Rebate Program Example: Trapelo Road facility, Massachusetts ....................... 14

2.2.2 State Rebate Program Example: Trenton Courthouse, New Jersey.............................. 14

2.2.3 State Rebate Program Example: New Windsor \& Jamaica Bay, New York ................ 14

2.2.4 Public Benefit Fund Example: Corvallis, Oregon ......................................................... 14

3 Photovoltaic Cost Savings and System Revenues ...................................................................... 16

$3.1 \quad$ Electricity Cost Savings ...................................................................................... 16

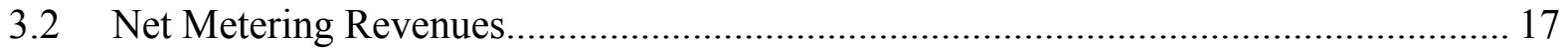

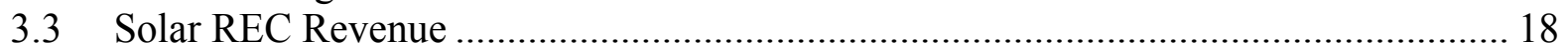

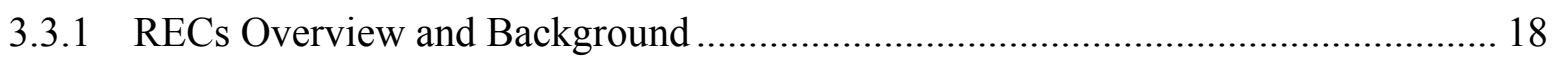

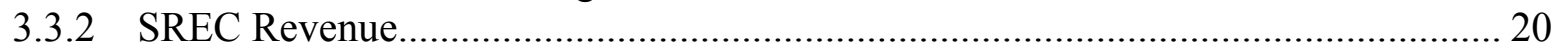

3.3.3 SRECs Example: General Services Administration Project, Colorado ..................... 22

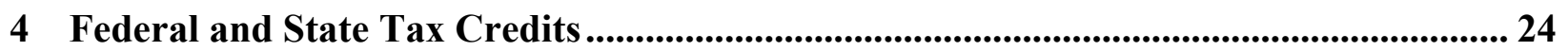

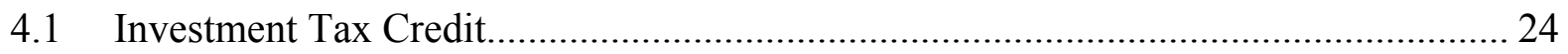

4.2 Modified Accelerated Cost-Recovery System and Bonus Depreciation ....................... 25

4.3 Appropriations to Federal Agencies .................................................................... 25

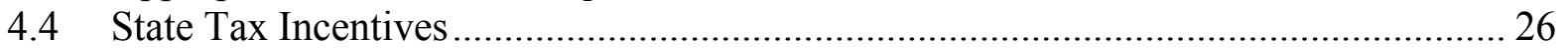

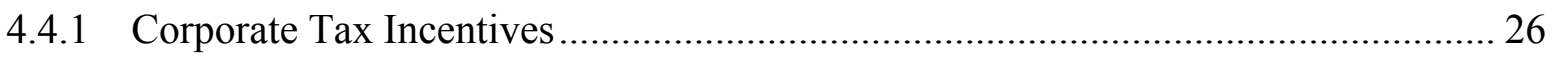

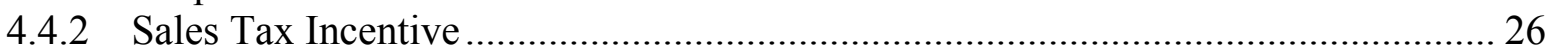

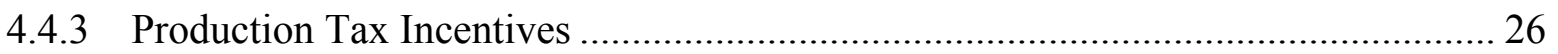

4.4.4 Federal Agency Use of State Tax Credit: Oregon Business Energy Tax Credit ...... 26 
$5 \quad$ Federal PV Financing Models......................................................................................... 28

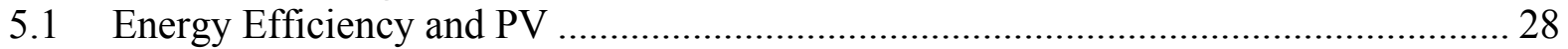

5.1.1 EE and PV Example: U.S. Postal Service Processing Center................................... 28

5.2 Third-Party Ownership/Power Purchase Agreement Model ........................................ 29

5.2.1 Third-Party/PPA Example: Nellis Air Force Base ……………………………….... 31

5.2.2 Third-Party Ownership/PPA Example: GSA Federal Building (CA) ……………... 31

5.3 PPA Contracting Intermediary: Western Area Power Administration .......................... 32

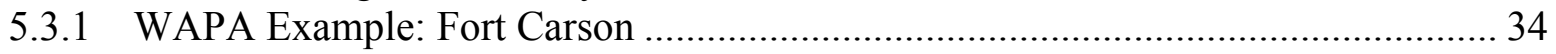

5.3.2 WAPA Example: National Renewable Energy Laboratory................................... 34

5.4 Energy Savings Performance Contracts and Utility Energy Service Contracts

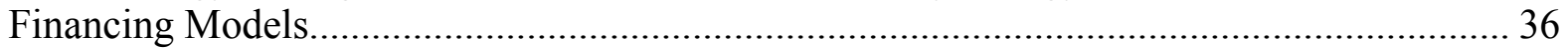

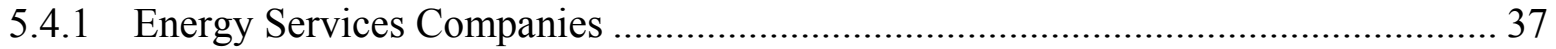

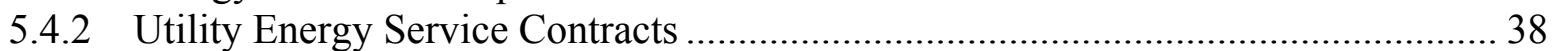

5.4.2.1 Utility Energy Service Contract PV Example: Camp Pendleton........................ 38

5.4.2.2 Utility Energy Service Contract PV Example: Chicago Social Security Center 38

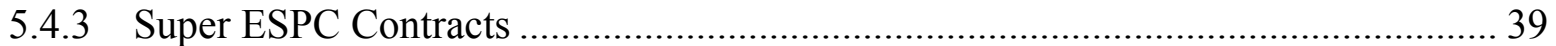

5.4.3.1 Super ESPC PV Example: Coronado Naval Base ............................................. 40

5.4.3.2 Super ESPC PV Example: Sher man Indian High School................................. 40

5.4.4 ESPC in Conjunction with Energy Services Agreement ........................................... 40

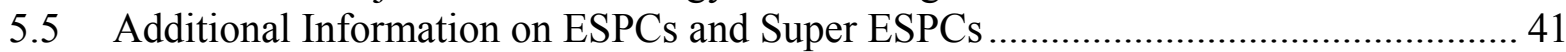

5.6 Multi-Year Construction for Federal System Ownership ............................................. 41

5.7 Summary of Federal PV Financing Models................................................................. 42

6 Federal Agency PV Revenue and Incentive Analysis .............................................................. 44

$6.1 \quad$ Solar Advisor Model Background ………………............................................ 44

6.2 PV Financing Analysis-Methodology and Assumptions .......................................... 45

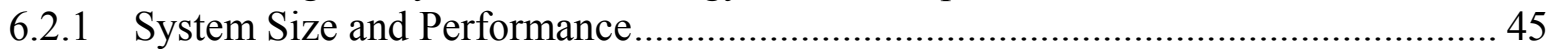

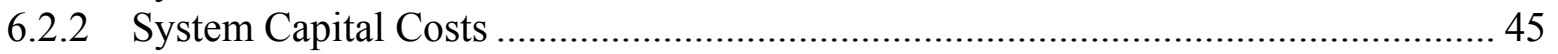

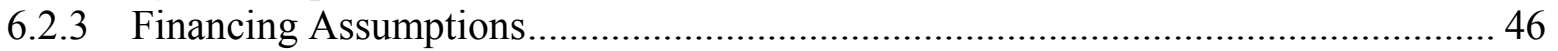

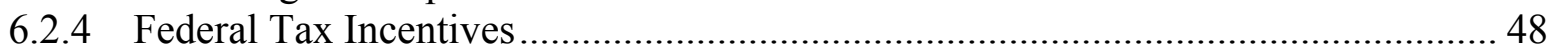

6.2.5 State-Specific Cash Incentives............................................................................ 48

6.2.6 State-Specific Solar Renewable Energy Credit Prices............................................ 49

6.2.7 Summary of Available Incentives and Assumed SREC Market Prices.................... 50

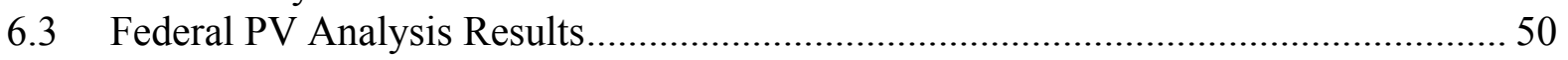

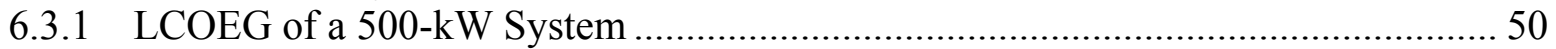

6.3.1.1 Benefit of Third-Party Ownership/PPA Financing …………………................ 51

6.3.1.2 The Importance of Federal Tax Incentives ………......................................... 52

6.3.1.3 The Importance of Cash Incentives ................................................................ 52

6.3.1.4 The Importance of SREC Revenue ................................................................. 53

6.3.1.5 Comparison of LCOEG With and Without Incentives and SREC Revenue ...... 53

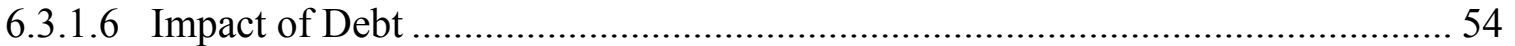

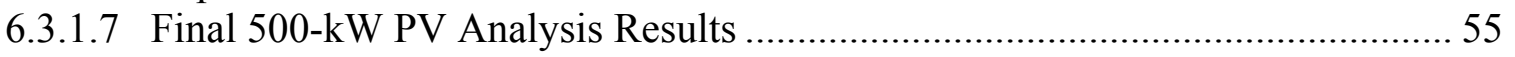

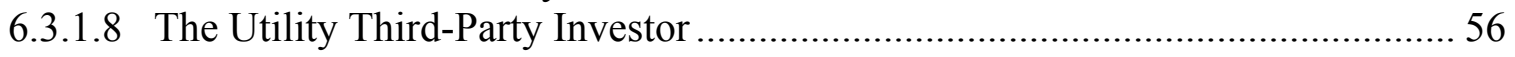

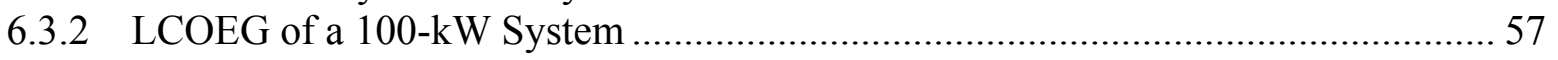

6.3.2.1 Benefit of Third-Party Ownership/PPA Financing ............................................ 58

6.3.2.2 The Importance of Federal Tax Incentives .................................................... 59 


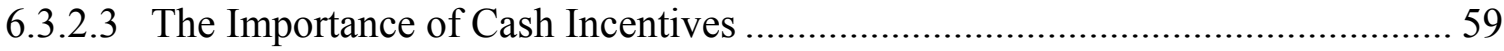

6.3.2.4 The Importance of SREC Revenues ......................................................... 59

6.3.2.5 Comparison of LCOEG With and Without Incentives and SREC Revenue ...... 59

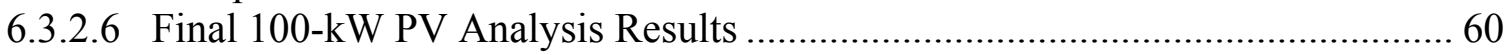

6.4 Federal PV System Analysis Conclusions ........................................................... 61

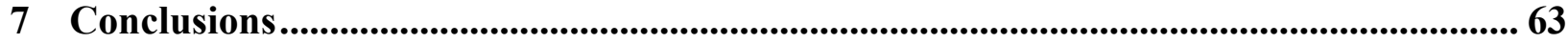

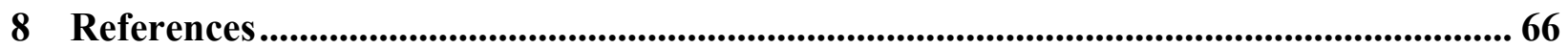

Appendix A. Federal Sector PV Deployment ................................................................. 80

Appendix B. Federal-Sector Eligibility for Net Metering .................................................. 81

Appendix C. Critical Steps in Executing the Third-party Ownership/PPA Model.............. 83

Appendix D. Critical Steps Using WAPA as a Contractual Intermediary.......................... 86

Appendix E. Critical Steps for Assessing Federal Project Potential....................................... 88

Appendix F. History of Relevant Legislation and Executive Orders.................................... 96

Appendix G. Energy Intensity Reductions and Renewable Energy's Role............................ 99

Appendix H. Useful Reference Documents and Internet Resources .................................. 101

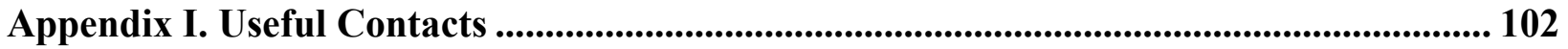




\section{List of Figures}

Figure 1. Federal renewable energy purchases and on-site generation ..................................... 7

Figure 2. System benefit charge funding of renewables by 2017 , by state ............................. 12

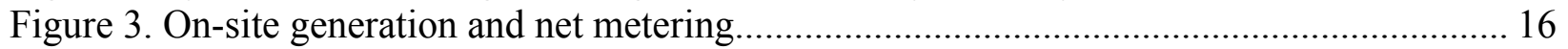

Figure 4. Retail price of electricity for commercial customers averaged for August 2008 (in

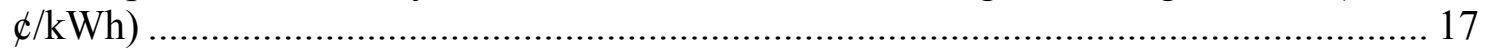

Figure 5. Solar/distributed generation provisions in state RPS policies ................................. 21

Figure 6. Contracts and cash flow in third-party ownership/PPA model ............................... 30

Figure 7. Third-party ownership/PPA model details (one variation) ..................................... 31

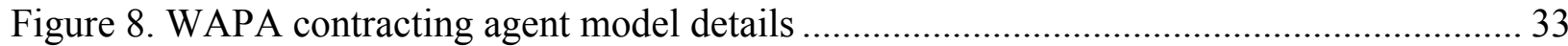

Figure 9. Dynamics of Mesa Top PV Project ........................................................................ 35

Figure 10. The LCOEG of $500 \mathrm{~kW}$ projects for federal agencies using different financial

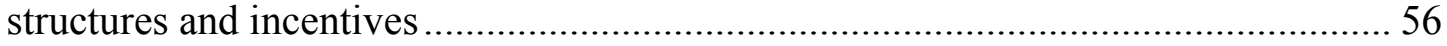

Figure 11. LCOEG after federal tax incentives for a $500 \mathrm{~kW}$ system in Colorado .................... 57

Figure 12. The LCOEG of $100 \mathrm{~kW}$ projects for federal agencies using different financial

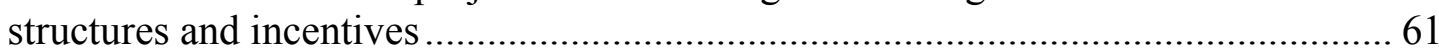

\section{List of Tables}

Table 1. Site Delivered Federal Agency Energy and Electricity Usage Data for FY 2006.......... 2

Table 2. Summary of Policy Drivers Influencing PV Deployment by Federal Agencies ............. 5

Table 3. Federal Agency Renewable Energy Generation and Purchases Data for FY 2006......... 6

Table 4. State and Utility PV Incentive Programs for Federal Agencies ................................. 13

Table 5. REC and SREC Prices in Voluntary and Compliance Markets................................... 20

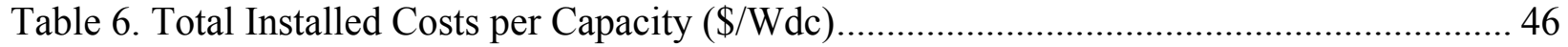

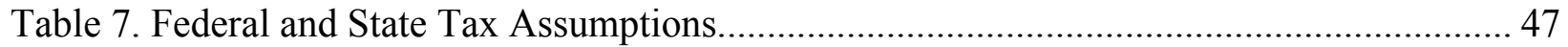

Table 8. State-Specific PV Cash Incentive and SREC Price Assumptions ................................ 50

Table 9. An LCOEG Comparison of Financing Structures and Average Retail Rate................ 51

Table 10. Comparison of LCOEG With and Without Incentives, for a $500 \mathrm{~kW}$ System............ 54

Table 11. LCOEG Comparison of Financing Structures and Average Retail Rate.................... 58

Table 12. Comparison of LCOEG With and Without Incentives for a $100 \mathrm{~kW}$ System............. 60

Table A-1. Select Examples of Federal Sector PV Deployment, by State and Project ............... 80

Table B-1. Federal-Sector Eligibility for Net Metering, by State............................................ 81

Table E-1. Optimal Sizes of Each Technology in Zoo Example ........................................... 93

Table E-2. Life-Cycle Cost of Business-as-Usual Case as Compared to the Zero-Energy Zoo

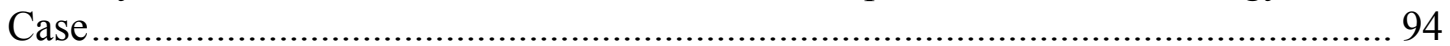

Table E-3. Cost-Effective Opportunities for Photovoltaics at Job Corps Centers...................... 94

Table G-1. Federal Building Energy Intensity (Btu Energy Use per Gross Square Foot)........... 99

Table G-2. Renewable Energy Purchase Contributions Toward Meeting Energy Intensity Requirements 


\section{Federal Sector Background: Energy and Electricity Use}

\subsection{Introduction}

The goal of this report is to help federal agencies understand how to finance photovoltaic systems deployed at their sites. Given the diverse range of financial and contractual options available in the marketplace, federal agencies must make sophisticated choices in order to capture as much of the economic potential of a PV system as possible. The first section of the report examines federal energy and renewable electricity use, reviews key federal goals and requirements, and highlights Department of Defense (DOD) and DOE renewable energy programs. Section 2 analyzes the state-based incentives for which federal agencies are eligible. Section 3 describes the cost savings and revenues (including SRECs) that result from on-site PV. State and federal tax incentives that can be utilized when working with or partnering with a private entity are covered in Section 4. Section 5 explores the various options for structuring the financing of PV on federal facilities and land including the ESPC, Super ESPC, ${ }^{5}$ UESC, and the third-party PPA ownership model. Finally, Section 6 explores the results from a quantitative analysis of the economics of PV projects, under various financing structures. The analysis shows how revenues and incentives combine to improve a project's economics.

As background, this section explains the overall energy use by the federal government, the energy intensity goals and requirements expected of federal agencies in existing and new buildings, and the current consumption of and requirements pertaining to renewable energy usage. Unless otherwise noted, data in this section is based on fiscal year (FY) 2006 information.

This information is presented to explore the importance of the federal government as a U.S. energy user, and the potential opportunity for federal-sector PV deployment in general. Specific attention is paid to the Department of Defense (DOD) and the Department of Energy (DOE), because these agencies are committed to increasing their on-site renewable energy usage (described in Section 1.5). Although the federal government could wield significant purchasing power in the United States, there are a number of barriers to on-site PV deployment at federal facilities, which are briefly explored. If the barriers are not addressed, then the opportunity for significant PV deployment in the federal sector might not be realized.

\subsection{Overview of Federal Energy Use ${ }^{6}$}

The United States federal government is the largest single energy consumer in the nation. In FY 2006 , the federal government accounted for approximately $1.5 \%$ of total primary ${ }^{7}$ energy consumption in the United States. Federal site-delivered ${ }^{8}$ energy consumption totaled nearly 1.06 quadrillion British thermal units (Btu) in FY 2006, 7.8\% less than in FY 2005. [1] The DOD alone accounted for nearly $80 \%$ of total federal sector site-delivered energy consumption in FY 2006, or 844 trillion Btu. [2] Conversely, the DOE accounted for only about 3.1\% of total federal sector site-delivered energy consumption. Although DOE energy consumption is much

\footnotetext{
${ }^{5}$ A Super ESPC loosens the contracting requirements whereby project specifics are not necessary.

${ }^{6}$ Useful conversion rates for electricity: 3,412 Btu/kilowatt hour and one quad is one quadrillion Btu $\left(10^{\wedge} 15\right.$ or $1,000,000,000,000,000 \mathrm{Btu})$.

7 "Primary energy consumption" includes all energy consumed to produce, process, and transport the energy.

8 "Site-delivered energy" only includes energy delivered to the point of use, and does not account for energy consumed in the production and delivery of energy products. Unless otherwise noted, data in this report uses sitedelivered energy.
} 
less than DOD, it is second only to the U.S. Postal Service (USPS) for civilian agencies. Government energy purchases cost approximately $\$ 17.7$ billion and accounted for $0.7 \%$ of total federal expenditures ( $\$ 2.655$ trillion) in FY 2006. [3] Of this, the DOD spent nearly $\$ 13.8$ billion on energy, accounting for $77.8 \%$ of the entire federal energy sector spending. [4]

Total energy consumption includes a variety of fuels used in various ways. Although more than $60 \%$ of energy consumption for the federal sector is attributed to vehicles and equipment (particularly fuel), nearly all of the electricity consumption is used in buildings. In FY 2006, electricity accounted for $17.6 \%$ of the total federal site-delivered energy consumption, and $24.1 \%$ of the total energy cost. [5] "Goal buildings," which include federal buildings that are subject to Energy Policy Act of 2005 (EPAct 2005) performance requirements, comprise 94.9\% of the total 3.2 billion square feet of federal space and present the greatest opportunities for PV development. "Excluded buildings," accounting for the remaining 5.1\% of federal space, "are comprised of structures and processes that are not qualified as federal buildings, buildings under construction or renovation, and certain types of leased space.” [6]

As shown in Table 1, in FY 2006 the DOD consumed 29,793 GWh of electricity, which was more than $54 \%$ of the total federal government electricity consumption for the year. The DOE was the second-largest electricity consumer of all civilian federal agencies (trailing the U.S. Post Office), consuming 4,901 GWh in 2006. [7]

Table 1. Site Delivered Federal Agency Energy and Electricity Usage Data for FY 2006

\begin{tabular}{|l|r|r|r|r|}
\hline Federal Agency & $\begin{array}{c}\text { Total Energy Use } \\
\text { (Billion Btu) }\end{array}$ & $\begin{array}{c}\text { \% of Federal } \\
\text { Energy Use }\end{array}$ & $\begin{array}{c}\text { Total } \\
\text { Electricity Use } \\
\text { (GWh) }\end{array}$ & $\begin{array}{c}\text { \% of Total } \\
\text { Federal } \\
\text { Electricity Use }\end{array}$ \\
\hline DOD & 843,708 & $79.6 \%$ & 29,793 & $54.4 \%$ \\
\hline DOE & 32,939 & $3.1 \%$ & 4,901 & $9.0 \%$ \\
\hline Other agencies & 182,875 & $17.3 \%$ & 20,037 & $36.6 \%$ \\
\hline Federal Government & $1,059,522$ & $100 \%$ & 54,731 & $100 \%$ \\
\hline
\end{tabular}

Source: "Annual Report to Congress on Federal Government Energy Management and Conservation Programs, Fiscal Year 2006," Department of Energy Federal Energy Management Program, Table 4 and A-2 on page 16 and 72 , http://www1.eere.energy.gov/femp/pdfs/annrep06.pdf.

\subsection{Federal Renewable Energy Requirements}

Federal agencies are interested in pursuing on-site PV projects for a number of reasons. Two of the main reasons - extending across all federal agencies - are the goals set by executive orders and the requirements set by legislation. ${ }^{9}$ Some federal agencies also have established goals. There are three main policies that encourage new PV deployment by federal agencies: (1) EPAct 2005, (2) Executive Order 13423 (EO 13423), and (3) the Energy Independence and Security Act of 2007 (EISA 2007). These policies have established and clarified targets that either directly or indirectly pertain to federal agency deployment of renewable energy. Note that, although EPAct 2005 and EISA 2007 constitute congressional laws, EO 13423 is a presidential executive order.

\footnotetext{
${ }^{9}$ Note that a detailed description of the laws and regulations over federal renewable energy use is provided in Appendix F and Appendix G.
} 


\subsubsection{Energy Policy Act of 2005}

Section 203 of EPAct 2005 requires that, to the extent economically feasible and technically practicable, federal government agencies use renewable electricity ${ }^{10}$ (relative to total electricity consumption) at the following levels:

- Not less than 3\% in fiscal years 2007 through 2009

- Not less than 5\% in fiscal years 2010 through 2012

- Not less than $7.5 \%$ in fiscal year 2013 and each fiscal year thereafter.

EPAct 2005 ( $§ 203$ ) also provides a bonus to federal agencies for qualifying, on-site renewable electricity used directly at a federal facility. For every kWh generated on-site, the agency receives double credit. This includes power used at a federal facility that is produced on-site, produced on federal lands, or produced on Indian land. [8] Note that if agencies use this bonus for the full EPAct 2005 requirement, then only 3.75\% of electricity use must be renewable in fiscal year 2013. If PV with a capacity factor of $17 \%$ is used to provide this on-site generation, this would equal 1,580 MW by 2013. Lastly, EPAct 2005 indicates that Congress believes that the Department of the Interior should approve at least 10,000 MW of non-hydro renewable electricity generation, for deployment on public lands.

\subsubsection{Executive Order 13423}

Executive Order 13423 was issued in January 2007, and clarified several expectations for meeting the EPAct 2005 federal renewable requirement. Specifically, EO 13423 explains that agencies should:

[E]nsure that (i) at least half of the statutorily required renewable energy consumed by the agency in a fiscal year [under EPAct 2005] comes from new renewable sources, and (ii) to the extent feasible, the agency implements renewable energy generation projects on agency property for agency use.

It is important to note that most of the renewable energy provisions in EO 13423 are complementary to EPAct 2005, but there are two exceptions. First, the EO clarifies that at least half of the renewable energy used to meet the EPAct 2005 requirement should be new, or on-line after January 1, 1999. Second, both electrical renewable energy and non-electrical ${ }^{11}$ renewable energy are eligible to qualify for EO 13423, whereas non-electrical renewable energy procured or produced to meet EO 13423 will not qualify for EPAct 2005.

Finally, EO 13423 specifies, "to the extent feasible, the agency [shall implement] renewable energy generation projects on agency property for agency use." Accordingly, federal agencies

\footnotetext{
${ }^{10}$ The "2007 FEMP Renewable Energy Requirement Guidance for EPAct 2005 and EO 13423” defines “"renewable energy" for EPAct 2005 as electric energy generated from solar, wind, biomass, landfill gas, ocean (including tidal, wave, current, and thermal), geothermal, waste to energy, hydrokinetic, or new hydroelectric generation capacity achieved from increased efficiency or additions of new capacity at an existing hydroelectric project. Note also that purchased renewable energy certificates (RECs) and some non-energy attributes apply. Found at "2007 FEMP Renewable Energy Requirement Guidance for EPAct 2005 and EO 13423," U.S. Department of Energy Federal Energy Management Program, pgs. 3-5, at http://www1.eere.energy.gov/femp/pdfs/ epact05_fedrenewenergyguid.pdf.

11 "Non-electric" renewable energy generally uses the same definition for applicable fuel sources as used for electric renewable energy in Footnote 10. The Guidance offers qualifying examples such as: thermal energy from solar ventilation pre-heat systems; solar heating and cooling systems; solar water heating; ground source heat pumps; biomass heating and cooling; and thermal uses of geothermal and ocean resources.
} 
will likely try to procure an increasing quantity of self-generated renewable electricity. As such, many federal agencies are likely to consider on-site PV deployment as a key method for meeting the renewable electricity requirement, particularly because agencies receive double credit toward EPAct 2005 renewable electricity requirements.

\subsubsection{EISA 2007}

Additional provisions affecting federal sector renewable energy deployment are established in EISA 2007. The Act codified into law an EO 13423 requirement that federal agencies reduce the energy intensity of their buildings 3\% per year from FY 2003 through FY 2015, to culminate in a $30 \%$ total reduction. [9] Although the ability to use renewable energy to meet this target is rapidly diminishing (to zero by 2012), the "Renewable Energy Requirement Guidance for EPAct 2005 and EO 13423," states that an exception is made for "small on-site renewable generation projects that do not incur fuel costs, are un-metered, and are located on the customer side of a facility's energy meter." [10] Therefore, in addition to energy efficiency activities, some federal agencies could choose behind-the-meter PV as one way to help meet energy intensity mandates. For additional background on federal energy intensity and renewable energy's role with energy intensity targets, see Appendix 8.

Lastly, in EISA 2007 § 433 ("Federal Building Energy Efficiency Performance Standards"), the DOE is directed to revise federal building standards so that the fossil energy use in new buildings (compared to 2003) be reduced [11] as indicated below.

- $55 \%$ by 2010

- $65 \%$ by 2015

- $80 \%$ by 2020

- $90 \%$ by 2025

- $100 \%$ by 2030

Energy efficiency and renewable energy offer the best means for reducing the fossil-fuel demand currently required by federal agencies.

\subsubsection{Agency Goals}

The National Defense Authorization Act of 2007 sets a goal for the Department of Defense to produce or procure at least $25 \%$ of total electricity consumption from renewable sources. This Act is discussed further in Section 1.5 (below). Note that, aside from the Defense Act, the policies outlined in this section are discussed in greater detail in Appendix F and Appendix G. Table 2 provides a brief summary of the goals and requirements which either directly or indirectly promote $\mathrm{PV}$ deployment in the federal sector. 
Table 2. Summary of Policy Drivers Influencing PV Deployment by Federal Agencies

\begin{tabular}{|c|c|}
\hline \multirow{3}{*}{ EPAct 2005} & $\begin{array}{l}\text { Federal government is required to increase its use of electricity from } \\
\text { renewable sources as a fraction of total electricity use, by: } \\
\text { - } 3 \% \text { or more from FY } 2007 \text { through 2009, } \\
\text { - } 5 \% \text { or more from FY } 2010 \text { through 2012, and } \\
\text { - } 7.5 \% \text { or more by } 2013 \text {. }\end{array}$ \\
\hline & $\begin{array}{l}\text { Bonus equivalent to doubling the amount of RE used or purchased so long } \\
\text { as the energy is used by a federal facility, and is produced on-site, on } \\
\text { federal lands, or on Indian lands (defined by title XXVI of the Energy Policy } \\
\text { Act of } 1992 \text { ( } 25 \text { U.S.C. } § 3501 \text { et seq.). }\end{array}$ \\
\hline & $\begin{array}{l}\text { "It is the sense of the Congress that the Secretary of the Interior should, } \\
\text { before the end of [2015], seek to have approved [10,000 MW of] non- } \\
\text { hydropower renewable energy projects located on public lands. . .." }\end{array}$ \\
\hline \multirow[t]{2}{*}{ EO 13423} & $\begin{array}{l}\text { Clarified that at least half of the EPAct } 2005 \text { RE requirement must be met } \\
\text { with energy from new renewable sources placed in service after January } 1 \text {, } \\
1999 .\end{array}$ \\
\hline & $\begin{array}{l}\text { Allows non-electric renewable resources to count toward the requirement } \\
\text { for new renewable energy. }\end{array}$ \\
\hline EISA 2007 & $\begin{array}{l}\text { Reduce fossil-fuel energy use of new federal buildings (compared to } 2003 \text { ) } \\
\text { by: } \\
\text { - } 55 \% \text { by } 2010 \text {; } \\
\text { - } 65 \% \text { by } 2015 \text {; } \\
\text { - } 80 \% \text { by } 2020 \text {; } \\
\text { - } 90 \% \text { by } 2025 \text {; and } \\
\text { - } 100 \% \text { by } 2030 \text {. }\end{array}$ \\
\hline $\begin{array}{l}\text { RE Requirement } \\
\text { Guidance for } \\
\text { EPAct } 2005 \text { and } \\
\text { EO } 13423\end{array}$ & $\begin{array}{l}\text { Declining qualification (to zero by 2012) of renewable energy toward } \\
\text { meeting EISA } 2007 \text { energy intensity reduction requirements, with } \\
\text { exception of small, behind-the-meter applications. }\end{array}$ \\
\hline $\begin{array}{l}\text { National } \\
\text { Defense } \\
\text { Authorization } \\
\text { Act of } 2007\end{array}$ & $\begin{array}{l}\text { DOD requirement "to produce or procure not less than } 25 \% \text { of the total } \\
\text { quantity of electric energy it consumes within its facilities and in its } \\
\text { activities during fiscal year } 2025 \text { and each fiscal year thereafter from } \\
\text { renewable energy sources. }\end{array}$ \\
\hline \multicolumn{2}{|c|}{$\begin{array}{l}\text { Sources: "2007 FEMP Renewable Energy Requirement Guidance for EPAct } 2005 \text { and EO 13423," U.S. } \\
\text { Department of Energy Federal Energy Management Program, at } \\
\text { http://www1.eere.energy.gov/femp/pdfs/epact05 fedrenewenergyguid.pdf; "Energy Independence and } \\
\text { Security Act of 2007," Enacted December 2007. Found at http://frwebgate.access.gpo.gov/cgi- } \\
\text { bin/getdoc.cgi?dbname=110 cong bills\&docid=f:h6enr.txt.pdf; United States Code Service: National } \\
\text { Defense Authorization Act 2007-Energy Performance Goals and plan for Department of Defense. Pg. } 2 . \\
\text { Found at http://www1.eere.energy.gov/femp/pdfs/ndaaa 2007.pdf. }\end{array}$} \\
\hline
\end{tabular}

Federal agencies have been challenged with an array of targets concerning an increase in renewable energy, improved energy intensity, and decrease in fossil-fuel consumption. The deployment of solar PV clearly meets the demands of renewable energy and fossil-fuel reduction goals, and even could play a small role in achieving energy intensity targets.

\subsection{Federal Renewable Energy Consumption}

Overall, federal renewable energy consumption in FY 2006 comprised 6.9\% of total electricity consumption in federal buildings - greatly exceeding the 3\% EPAct 2005 target for 2007. [12] Less than half of all federal agencies, however, individually have been able to meet or exceed the EPAct 2005 renewable energy requirements (specific compliance with EO 13423 is not known 
as this program began in FY '07). The DOD in particular has contributed significantly to the federal government's renewable energy mandates. In FY 2006, the DOD accounted for $2,823 \mathrm{GWh}$ of used or purchased renewable energy. This was $9.5 \%$ of the DOD's total electricity consumption, and $75 \%$ of the total renewable energy reported by the entire federal sector. [13] [14] Table 3 provides the statistics of self-generated and purchased renewable energy, total electricity use, and the associated percentage for DOD, DOE, and the remaining federal agencies.

Table 3. Federal Agency Renewable Energy Generation and Purchases Data for FY 2006

\begin{tabular}{|c|c|c|c|c|c|}
\hline $\begin{array}{l}\text { Federal } \\
\text { Agency }\end{array}$ & $\begin{array}{l}\text { Self-Generated } \\
\text { Renewable } \\
\text { Energy (GWh) } \\
\end{array}$ & $\begin{array}{c}\text { Purchased } \\
\text { Renewable } \\
\text { Energy } \\
\text { (GWh) } \\
\end{array}$ & $\begin{array}{c}\text { Total } \\
\text { Renewable } \\
\text { Energy } \\
\text { (GWh) } \\
\end{array}$ & $\begin{array}{l}\text { Total } \\
\text { Electricity } \\
\text { Use (GWh) } \\
\end{array}$ & $\begin{array}{c}\text { Percentage of } \\
\text { Renewable Energy to } \\
\text { Total Electricity Use }\end{array}$ \\
\hline DOD & 1,140 & 1,683 & 2,823 & 29,793 & $9.47 \%$ \\
\hline DOE & 4 & 138 & 142 & 4,901 & $2.91 \%$ \\
\hline $\begin{array}{l}\text { Other } \\
\text { agencies }\end{array}$ & 37 & 343 & 813 & 20,037 & $4.06 \%$ \\
\hline $\begin{array}{l}\text { Federal } \\
\text { Government }\end{array}$ & 1,181 & 2,597 & 3,778 & 54,731 & $6.90 \%$ \\
\hline
\end{tabular}

In FY 2006, 68.7\% of federal agency renewable energy use was from purchased renewable electricity (bundled with RECs), unbundled RECs (without associated power), and landfill gas. Self-generated energy, including electricity, solar thermal applications, and geothermal heat pump installations comprised the remaining $31.3 \%$ of renewable energy use. Note that, of the federal government's total renewable energy use, only $8.8 \%$ comes from on-site electricity generation from photovoltaics, wind, and other renewable sources. [15] Total federal renewable energy purchases and on-site renewable energy generation is shown in Figure 1. It is important to note that on-site renewable electricity generation is not differentiated in this figure. 


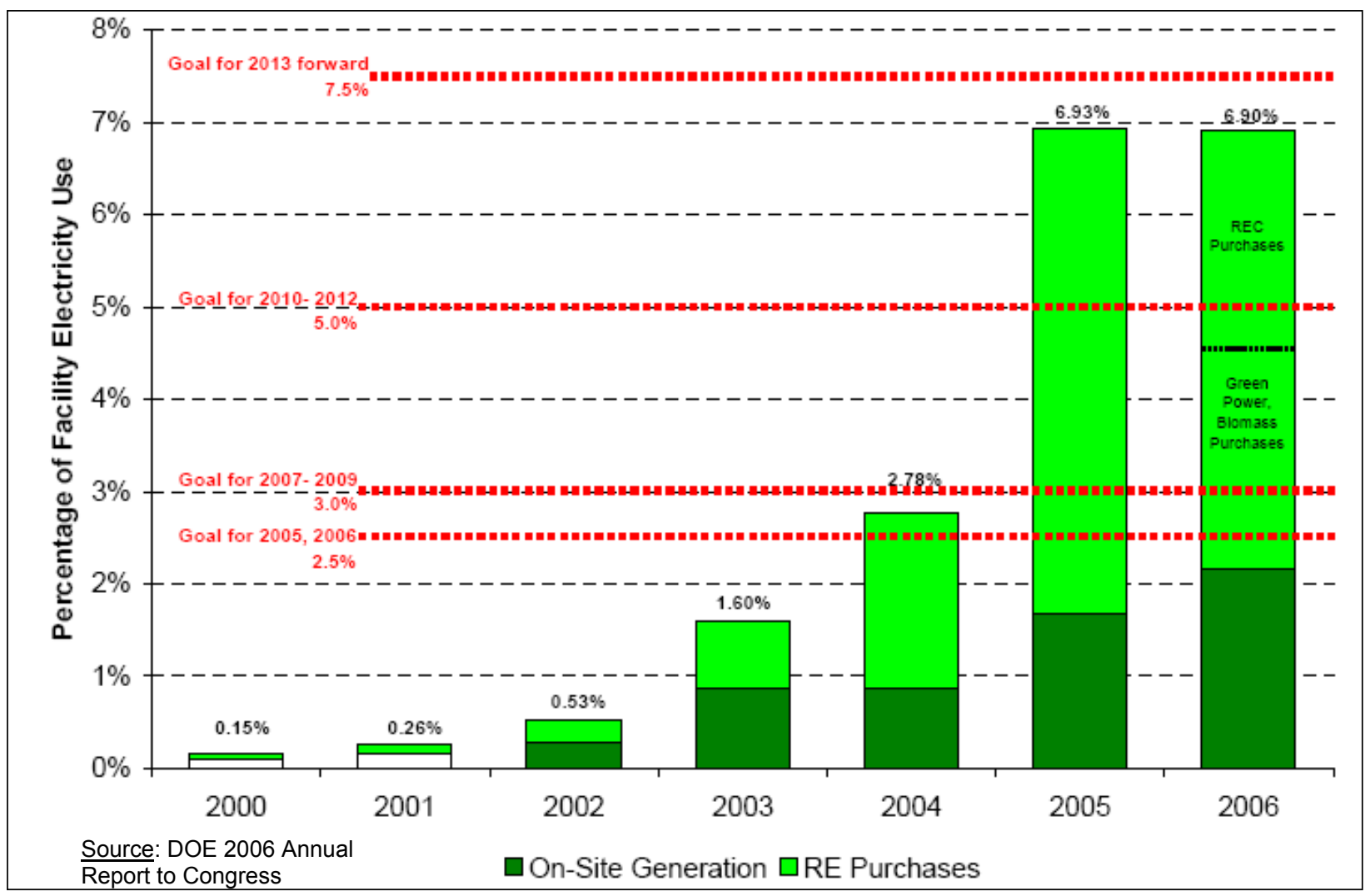

Figure 1. Federal renewable energy purchases and on-site generation

Although this report highlights activities of the DOD and DOE in particular, other federal agencies have an important role to help the government achieve its goal of renewable deployment. In fact, in parts of the country that have greater than average electricity prices, other federal agencies might have a better opportunity for PV development. In many regions the DOD and DOE have leveraged their buying power to reduce their electricity rates to below the average. The result is that the price of electricity from a PV unit can seem relatively greater, because there is a bigger disparity between the cost of the system compared to negotiated utility electricity rates. Additionally, the energy-efficiency programs at the DOD already have taken advantage of many of the low-cost, simple energy conservation measures (ECMs) that pay for themselves in just a few years. Federal agencies that have not yet performed a full-scale site energy audit and are located in areas that have higher electricity prices, could combine energy efficiency efforts with PV deployment, pay a smaller incremental amount, and enjoy a shorter payback period.

\subsection{Federal Leadership: DOD and DOE}

The aggressive programs of DOD and DOE and the individual agency efforts in pushing renewable energy — such as PV - are examined more closely below. To meet the energy requirements successfully requires creative policies, financial incentives, and committed program administrators. Federal agencies interested in meeting their own requirements and goals can learn valuable lessons from DOD and DOE activities. 


\subsubsection{DOD 25\% Renewable Energy Goal by 2025}

In 2006, the U.S. Senate approved a measure creating a goal for the DOD to get $25 \%$ of its electricity from renewable sources by 2025. A year later, the National Defense Authorization Act of 2007 turned the DOD goal into a requirement "to produce or procure not less than $25 \%$ of the total quantity of electric energy it consumes within its facilities and in its activities during fiscal year 2025 and each fiscal year thereafter from renewable energy sources (as defined in section 203(b) of the Energy Policy Act of 2005)." [16] [17] As explained above, the DOD consumes more than $50 \%$ of total federal electricity consumption. This $25 \%$ requirement is above and beyond the EPAct 2005 requirement of achieving a 7.5\% renewable energy contribution to overall federal energy use by 2013.

The DOD has a history of surpassing the clean-energy mandates and goals; therefore it is likely that DOD also will meet the 25\% goal. The EO 13423 goal (later codified by EISA 2007) requested federal agencies to reduce their energy intensity by at least $6 \%$ from 2003 to 2007 , for example, and the DOD reduced its energy intensity by $10.1 \%$. Similarly, the DOD surpassed the EPAct 2005 requirement that at least 3\% of total electricity usage be renewable in FY 20072009 by supplying $5.5 \%$ of its electricity needs with renewable purchases or self-generation. [18] Further, EO 13423 set the target that at least half of the 3\% renewable energy (1.5\%) be from new sources (installed in 1999 or later). The DOD used 3.3\% new renewable energy, well exceeding that goal.

The Department of Navy and the Air Force are leaders within the DOD in pursuing selfgenerated renewable energy projects. The Navy operates the largest wind/diesel hybrid plant in the world, as well as the some of largest federal PV systems in the United States. [19] Nellis Air Force Base operates the largest solar PV system in the United States as of mid-2008. Several of these projects are described in more detail elsewhere in this report.

\subsubsection{The DOE's Transformational Energy Action Management Initiative}

In 2007, the Department of Energy launched the Transformational Energy Action Management (TEAM) Initiative, in response to EO 13423. The TEAM Initiative is driven by the DOE's desire to be the nation's leader in energy efficiency, renewable energy generation and use, and petroleum reduction and alternative fuel use. Among its numerous goals, the underlying initial target is "to have all of its national facilities reduce their energy consumption by $30 \%$ and water consumption by $16 \%$ by the end of fiscal year 2009." [20] Further, all new construction must meet or exceed a LEED Gold standard. ${ }^{12}$

The goals established in EO 13423 and by the TEAM Initiative are captured in DOE Order 430.2B. The Order required the DOE sites to submit executable plans for achieving the DOE and TEAM goals by December 31, 2008. [21] Also, by the end of 2008, the TEAM Initiative set a goal for the DOE to have renewable energy agreements in place at as many sites as are needed to fulfill and exceed the EPAct 2005 requirements and EO targets for renewable energy consumption. [22] For the DOE, 7.5\% of its electricity consumption is equivalent to roughly $370 \mathrm{GWh}$. With the doubling credit (or bonus) for on-site generation, DOE would need to secure $185 \mathrm{GWh}$

\footnotetext{
${ }^{12}$ More information about the Leadership in Energy and Environmental Design (LEED) Green Building Rating System can be found at http://www.usgbc.org/Displaypage.aspx?categoryID=19 (accessed June 5, 2009).
} 
of renewable energy by 2013 to meet the EPAct 2005 mandate. [23] Assuming an average capacity factor of $18 \%$, this would require the equivalent of nearly $120 \mathrm{MW}$ of PV.

The DOE TEAM Initiative recommends six strategies for achieving the renewable energy consumption goal, including [24] the following:

1. Develop life-cycle cost-effective on-site projects that will meet the goal using private financing.

2. Maximize direct purchases which facilitate new renewable energy projects.

3. Incorporate renewable technologies into new construction where feasible.

4. Minimize reliance on REC purchases.

5. Maximize DOE land for new renewable energy projects.

6. Initiate legislative and policy changes for implementation.

To achieve the aggressive goals laid out by the TEAM Initiative, the DOE will utilize private sector financing, such as ESPCs, UESCs, and third-party owned systems with PPAs. Energy savings performance contracts enable the government to avoid up-front costs by contracting out the financing, installation, and maintenance of energy equipment. The private companies that own and operate the asset are repaid over time by the agency from the cost savings produced by the new equipment. [25] This strategy enables the government (and therefore taxpayers) to avoid the burden of paying the up-front costs. A UESC uses a similar process as does the ESPC, however it is the utility that covers the financing for the capital costs of the project and, in turn, is paid back by the energy savings. A more detailed discussion of ESPCs, UESCs, and thirdparty owned PPAs is included in Section 5.

The Department of Defense and DOE strive to be federal leaders in clean energy implementation. Congress established a DOD goal of 25\% renewable energy by 2025 and the DOD has a history of surpassing its targets. DOE has the TEAM Initiative geared to reduce energy and water consumption, as well as exceed renewable energy mandates and goals. These two agencies take advantage of state incentives and new financing structures to deploy PV at their sites. The next few sections describe the incentives and market mechanisms that federal agencies can use to help pay for on-site PV systems.

\subsection{Barriers to PV Deployment in the Federal Government}

If all of the 2,890 GWh of federally purchased renewable electricity was replaced with on-site PV (at an 18\% capacity factor), the federal government would need to deploy 1,833 MW. To put this in perspective, this is more than 6 times the $292 \mathrm{MW}_{\mathrm{DC}}$ annual grid-tied PV capacity installed in the nation in 2008. [26] Additionally, if 10\% of the federal government's electricity were to come from on-site PV, the federal government could deploy 4,490 MW.

There are, however, a number of barriers that the federal government faces to deploying PV on a large scale. Some common barriers to PV deployment are shared with the private sector and some are unique challenges that are more government specific. Some of the obstacles federal agencies have experienced include the following.

Up-Front Cost. Although PV costs have been reduced significantly in recent years, the cost still is substantially greater than most ECMs, and (in most of the United States) also is more than electric utility rates. Lawrence Berkeley National Laboratory reported 2007 national average 
installed PV prices of $\$ 7.60 / \mathrm{kW}$ and a real long-term decline in prices of 3.5\% per year. [27] It generally is challenging for federal agencies to secure such capital in their budgets, however the Recovery Act has set aside $\$ 5.55$ billion in appropriations to make federal buildings more energy efficient. ${ }^{13}$ The mechanism to access these funds, however, still is unclear-some could be allocated directly to federal agencies, some will be available competitively, and there might be other rules. Federal agencies should make efforts now to secure funding available under the Recovery Act.

Limited Contract Authority. Most federal agencies have limited contract authority that could prohibit them from entering into contracts with PV developers or investors. In particular, many agencies cannot enter contracts that extend 10 or more years, yet most PV contracts in 2008 had durations of 20 years or longer.

Space Limitations. Not all agencies have rooftop space or land that is suitable for hosting PV systems. Trees, other buildings, and other roof-top equipment can shade PV, rendering it ineffective for many hours a day and, thus, impractical.

Resource Limitations. Not all federal agencies are located in areas that have a great solar resource for harnessing electricity from a PV system. Note that, although the solar resource is a consideration, it should not be the only one. Increased incentives can compensate for a reduced solar resource, as evidenced in (1) New Jersey, a state having unremarkable solar resources, but which has deployed much PV capacity in recent years due to the state-level incentives.

Declining Bundling Opportunities. Many PV projects are more financially feasible when bundled with other ECMs. Some of the best ECM opportunities, however, already might have been tapped, leaving fewer remaining energy conservation projects to combine with on-site PV.

Military Housing and Other Building Privatization. Private ownership of a building that the federal government rents can present a challenge. The private landlord must be convinced of the value of deploying PV on the site (and typically entering a commitment of 20 years or longer), despite the fact that the government's lease might not extend for the same length of time.

Lack of Information. Many agencies lack information on their facilities which can be important to help projects attain financing. Site characteristics such as roof age are needed to know if a project is feasible. Additionally, the federal infrastructure is aging - to the extent that old facilities will be replaced with new ones; this could mean that deploying solar on the old facility does not make economic sense.

In summary, the federal sector is large and subsequently spends a significant amount of money on energy, particularly electricity. As such, the federal government has the opportunity to deploy significant levels of PV in the coming years. There are numerous challenges, however, that must be addressed for successful federal PV deployment.

\footnotetext{
${ }^{13}$ See "Key Provisions Benefiting the Solar Energy Industry in the American Recovery and Reinvestment Act," Solar Energy Industries Association, at http://seia.org/galleries/pdf/exec_summary_of final_bill_2_17_09.pdf (accessed June 5, 2009).
} 


\section{State and Utility Cash Incentives}

This section explores state- and utility-level incentives for federal agencies that promote PV. Because of the high up-front cost, on-site PV projects at federal agencies are not likely to meet purchasing and payback requirements unless the project can secure additional incentives. Some states and utilities offer sizable cash incentives to federal projects, either as up-front incentives (at the time of installation), or as performance-based incentives that are paid out as the system generates power.

Generally, federal agencies are eligible for these state or utility incentives so long as the programs are based on customer class or tariff regulation. This is supported by the legislative authority of the National Energy Conservation Policy Act, 42 U.S.C. $\S 8256$, which states under section c(2), "Each agency may accept any financial incentive, goods, or services generally available from any such utility to increase energy efficiency or to conserve water or to manage electricity." [28] Potential exceptions to this rule are interconnection and net-metering standards which are created through a state's independent laws.

\subsection{Cash Incentives-SBC Funds}

The primary source of cash incentives for on-site federal PV in many states comes from programs that are funded by a system benefits charge (SBC), sometimes called a public benefit fund. ${ }^{14}$ The sources of these programs often are mandated through state legislation, but also can be created by regional utility and or municipal programs. A standard stipulation for securing SBC incentives is that beneficiaries must be utility ratepayers. Therefore, federal agencies that are customers of utilities with SBC programs typically are eligible to participate in SBC-funded programs, as they pay the same surcharge on their electricity bill as all other customers pay.

Since the mid 1990s, 16 states and the District of Columbia have implemented some variation of SBC funds $[29]^{15}$ to support renewable energy. ${ }^{16}$ The implementation of these SBC programs originated as a result of state-specific electric utility restructuring legislation.[30] The SBC is a required fee that is added to electricity bills - usually in the form of a usage charge (per kWh basis) or as a monthly flat fee. Although the fee usually is modest to the consumer, in aggregate significant funds are generated using this mechanism, as shown in Figure 2. According to the North Carolina Solar Center, between the years 1997 and 2017, \$7.3 billion dollars will be raised for renewable energy programs via the system benefit charge mechanism. On its own, California will collect nearly \$364 million just in 2009. [31] PV is one of several renewable energy technologies (in addition to energy-efficiency technologies) eligible for these funds in most states. The amount allocated to each technology is state-specific and depends on the program's goals.

Cash incentives are available for PV projects located at federal sites in several states. If a federal agency owns the PV system, then it directly receives the incentive. If the agency has partnered with a third-party owner, then the owner usually receives the incentive and passes the economic benefit through a lower electricity PPA price over the length of the contract. Table 4 provides a list of state and utility cash incentive programs for which federal agencies are eligible, including

\footnotetext{
${ }^{14}$ Other state incentives exist that are funded using other mechanisms, which are not described in detail.

${ }^{15}$ Latest review depends on the state.

${ }^{16}$ In addition to renewables, some states use SBC funds to target energy efficiency, energy research and development, weatherization, and low-income customer assistance.
} 
their various stipulations. This is not a comprehensive list for all programs of which federal agencies are eligible.

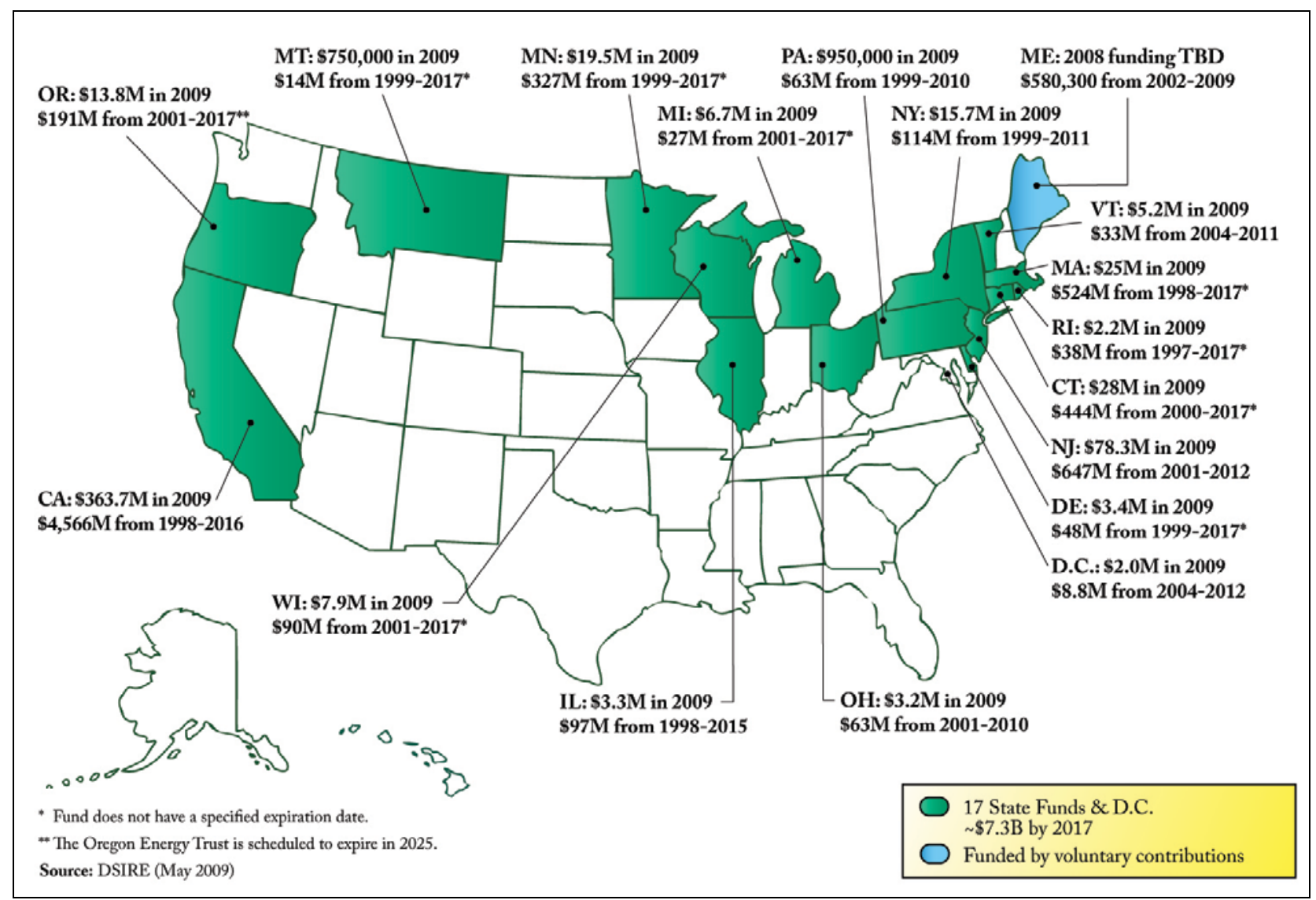

Figure 2. System benefit charge funding of renewables by 2017 , by state Source: Database of State Renewable and Efficiency Incentives (http://www.dsireusa.org) 
Table 4. State and Utility PV Incentive Programs for Federal Agencies

Examples of Incentives for which Federal Agencies are Eligible

\begin{tabular}{|c|c|c|c|c|c|c|}
\hline State & Program & \multicolumn{2}{|c|}{ Watt Parameters } & Incentive & \$/W Max Limit & Notes \\
\hline \multirow[t]{2}{*}{ CA } & \multirow[t]{2}{*}{$\begin{array}{l}\text { California Solar } \\
\text { Initiative }\end{array}$} & \multicolumn{2}{|c|}{$<50 \mathrm{~kW}$} & $\begin{array}{l}\begin{array}{l}\$ 3.25 / \mathrm{W} A C, \\
\text { adjusted based } \\
\text { on expected } \\
\text { performance }\end{array} \\
\end{array}$ & & \multirow{2}{*}{$\begin{array}{l}\text { Under 50kW can opt into } \\
\text { performance-based incentive } \\
\text { (PBI), but all systems above } \\
50 \mathrm{~kW} \text { must use PBI }\end{array}$} \\
\hline & & \multicolumn{2}{|c|}{$\geq 50 \mathrm{~kW}$} & $\begin{array}{l}\$ 0.50 / \mathrm{kWh} \text { for } \\
\text { first } 5 \text { years }\end{array}$ & & \\
\hline \multirow{3}{*}{$\mathrm{CO}$} & \multirow{3}{*}{$\begin{array}{l}\text { Xcel Energy: } \\
\text { Solar*Rewards }\end{array}$} & \multicolumn{2}{|c|}{$.5 \mathrm{kw}$ to $10 \mathrm{~kW}$} & $\$ 2$ per Watt DC & $\$ 35,000$ & \multirow{3}{*}{$\begin{array}{l}\text { Rebate program includes } \\
\text { REC pymts: }<10 \mathrm{~kW}= \\
\$ 1.50 / \mathrm{W} ; 10.1-100 \mathrm{~kW}= \\
\$ .115 / \mathrm{kWh} ; 100.1 \mathrm{~kW}-2 \mathrm{MW}= \\
\text { RFP process }\end{array}$} \\
\hline & & $10.1 \mathrm{~kW}$ & $100 \mathrm{~kW}$ & $\$ 2$ per Watt DC & $\$ 200,000$ & \\
\hline & & \multicolumn{2}{|c|}{$100.1 \mathrm{~kW}$ to $2 \mathrm{MW}$} & $\begin{array}{l}\text { Determined } \\
\text { through RFP } \\
\text { process }\end{array}$ & $\$ 200,000$ & \\
\hline \multirow{2}{*}{ CT } & \multirow{2}{*}{$\begin{array}{l}\text { CT Clean } \\
\text { Energy Fund }\end{array}$} & \multicolumn{2}{|c|}{$\leq 10 \mathrm{~kW}$} & $\$ 4.75 /$ Watt & & \\
\hline & & \multicolumn{2}{|c|}{$>10 \mathrm{~kW}$} & Varies by system & & \\
\hline \multirow{2}{*}{ DC } & \multirow{2}{*}{$\begin{array}{l}\text { Renewable } \\
\text { Energy } \\
\text { Demonstration } \\
\text { Project } \\
\end{array}$} & \multicolumn{2}{|c|}{ Res. $\leq 3 \mathrm{~kW}$} & \$3/Watt & $\$ 9,000$ & \multirow{2}{*}{$\begin{array}{l}\text { Completed fourth round } \\
\text { solicitations in } 08 / 08 \text { '. Will } \\
\text { soon announce fifth round for } \\
2009\end{array}$} \\
\hline & & \multicolumn{2}{|c|}{ Non-res. $\leq 8 \mathrm{~kW}$} & $\$ 2.50 /$ Watt & $\$ 20,000$ & \\
\hline FL & $\begin{array}{l}\text { Solar Energy } \\
\text { Systems } \\
\text { Incentives } \\
\text { Program } \\
\end{array}$ & \multicolumn{2}{|l|}{$\geq 2 \mathrm{~kW}$} & $\$ 4 / \mathrm{W}$ & $\$ 100,000$ & \\
\hline MA & $\begin{array}{l}\text { MTC - } \\
\text { Commonwealth } \\
\text { Solar Rebates }\end{array}$ & \multicolumn{2}{|c|}{$>1 \mathrm{~kW} \leq 500 \mathrm{~kW}$} & $\begin{array}{l}\$ 1.50-\$ 5.50 / \mathrm{W} \\
\text { depending on } \\
\text { size }\end{array}$ & $\begin{array}{l}\text { \$1.6 million per } \\
\text { calendar year for } \\
\text { non-residential } \\
\text { applicants }\end{array}$ & $\begin{array}{l}\text { Public buildings receive } \\
\text { additional } \$ 1 / \mathrm{W} \text { in rebate }\end{array}$ \\
\hline MN & $\begin{array}{l}\text { Solar Electric } \\
\text { Rebate } \\
\text { Program }\end{array}$ & \multicolumn{2}{|c|}{$\geq 0.5 \mathrm{~kW} \leq 10 \mathrm{~kW}$} & $\begin{array}{l}\$ 2-\$ 2.25 / \mathrm{W} \\
\text { depending on } \\
\text { installer }\end{array}$ & $\begin{array}{l}\$ 20,000-22,000, \\
\text { though larger } \\
\text { systems considered } \\
\text { case by case }\end{array}$ & $\begin{array}{l}\text { Administered by the MN } \\
\text { Office of Energy Securities, } \\
\text { funded by Xcel }\end{array}$ \\
\hline NJ & $\begin{array}{l}\text { Clean Energy } \\
\text { Fund }\end{array}$ & \multicolumn{2}{|c|}{$\begin{array}{l}\text { Up to } 1 \mathrm{MW} \text {; incentives } \\
\text { are disbursed only for } \\
\text { the first } 700 \mathrm{~kW} \text {. } \\
\text { Effective March } 1,2008 \text {, } \\
\text { projects that use only } \\
\text { private-sector PPA } \\
\text { receive rebates for first } \\
100 \mathrm{~kW} \text { of rated capacity }\end{array}$} & $\begin{array}{l}\$ 1.85-\$ 4.10 / W \\
\text { DC (varies by } \\
\text { technology, } \\
\text { capacity and } \\
\text { applicant type) }\end{array}$ & $\$ 245,000$ & $\begin{array}{l}\text { As of Dec. } 2007 \text {, applications } \\
\text { are no longer accepted. It is } \\
\text { anticipated that rebates for } \\
\leq 20 \mathrm{~kW} \text { systems will continue } \\
\text { in some form during } 2009 \text { - } \\
2012 ; \text { rebates for larger } \\
\text { systems will be discontinued }\end{array}$ \\
\hline \multirow{2}{*}{ NY } & \multirow{2}{*}{$\begin{array}{l}\text { NYSERDA: } \\
\text { PV Incentive } \\
\text { Program }\end{array}$} & \multicolumn{2}{|c|}{ up to $25 \mathrm{~kW}$} & \multirow{2}{*}{$\begin{array}{l}\text { \$3-5/W : } \\
\text { dependent on } \\
\text { size and res. vs. } \\
\text { non-res }\end{array}$} & \multirow{2}{*}{$\begin{array}{l}\text { Systems may not } \\
\text { exceed } 110 \% \text { of } \\
\text { demonstrated energy } \\
\text { demand }\end{array}$} & \multirow{2}{*}{$\begin{array}{l}\text { Rebate is highest for public } \\
\text { projects }\end{array}$} \\
\hline & & \multicolumn{2}{|c|}{$>25 \mathrm{~kW}$ and $\leq 50 \mathrm{~kW}$} & & & \\
\hline \multirow{4}{*}{ OR } & \multirow{4}{*}{$\begin{array}{l}\text { Solar Electric } \\
\text { Buy-Down } \\
\text { Program }\end{array}$} & \multirow{2}{*}{$\begin{array}{l}\text { Pacific } \\
\text { Power }\end{array}$} & $<30 \mathrm{~kW}$ & $\$ 1.25 / \mathrm{W}$ & \multirow[b]{2}{*}{$\$ 150,000$} & \\
\hline & & & $>100 \mathrm{~kW}$ & $\begin{array}{l}\$ 1 / \mathrm{W} \text { for } 1 \mathrm{st} \\
100 \mathrm{~kW}\end{array}$ & & $\begin{array}{l}\text { Note: The per-watt incentive } \\
\text { rate declines linearly for }\end{array}$ \\
\hline & & & $<30 \mathrm{~kW}$ & $\$ 2 / \mathrm{W}$ & & systems sized between 30 \\
\hline & & PGE & $>100 \mathrm{~kW}$ & $\begin{array}{l}\$ 1.25 / \mathrm{W} \text { for } 1 \mathrm{st} \\
100 \mathrm{~kW}\end{array}$ & $\$ 175,000$ & \\
\hline WI & $\begin{array}{l}\text { Focus on } \\
\text { Energy }\end{array}$ & $>.5 \mathrm{~kW}$ & $20 \mathrm{~kW}$ & $\begin{array}{l}35 \% \text { of project } \\
\text { costs, or } \$ 35,000\end{array}$ & $\$ 35,000$ & $\begin{array}{l}\text { As of July } 1,2008, \text { federal } \\
\text { agencies are eligible for this } \\
\text { program }\end{array}$ \\
\hline
\end{tabular}

Sources: DSIRE, Connecticut Clean Energy Fund, Massachusetts Technology Collaborative (MTC) Renewable Energy Trust, Minnesota Solar Electric Rebate Program, New York State Energy Research and Development Authority (NYSERDA), Energy Trust of Oregon, Inc. 


\subsection{Use of SBC Funds - Examples}

SBC funds are used to support a variety of renewable energy-related activities through grants, loans, rebates, performance-based incentives, and free technical assistance. A few examples of state SBC programs that directly resulted in federal PV facilities include the following.

\subsubsection{State Rebate Example: Trapelo Road facility, Massachusetts}

Two federal PV projects were funded in Massachusetts and one is currently operational. [32] First, the U.S. General Services Administration (GSA) installed $378 \mathrm{~kW}$ of PV at its Trapelo Road facility in February of 2007. The project cost a total of \$5 million. GSA applied for and received a \$50,000 grant from the Massachusetts Renewable Energy Trust (Trust), under its Small Renewables Initiative, which is a rolling rebate program. According to Trust project managers, this was thought to have been done as part of a Super ESPC contract and was interconnected through the local utility, NSTAR. The second project is an $11-\mathrm{kW}$ system at the Lowell National Historic Park. The project had been stalled for 4 years as the park managers attempted to secure matching federal funds. In May 2008, these funds were obtained and the project is moving forward towards installation. The construction cost is estimated at $\$ 99,172$, and the project also should be eligible for a $\$ 50,000$ grant from the Trust.

\subsubsection{State Rebate Example: Trenton Courthouse, New Jersey}

One federal PV project was funded and completed in Trenton, New Jersey, at another GSA facility. A 41-kW system was installed at the Trenton Courthouse Annex. The cost of this project was approximately $\$ 347,000$, but a rebate of nearly $\$ 150,000$ was received from the New Jersey Clean Energy Fund. [33] The rebate covered about 43\% of the up-front system costs.

\subsubsection{State Rebate Example: New Windsor \& Jamaica Bay, New York}

Two federal PV projects were completed in New York with funding from the renewable portfolio standard (RPS) surcharge, administered by the New York State Energy Research and Development Authority (NYSERDA). The first system, with $15.84 \mathrm{~kW}$ of PV capacity, was installed at a United States Army facility in New Windsor. The total cost of the system was $\$ 114,793$ and the incentive received was in the amount of $\$ 63,360$ (more than $55 \%$ of system cost). A second installation (total system size of $5.824 \mathrm{~kW}$ ) was installed at Jamaica Bay Wildlife Refuge's Gateway National Recreation Area in Far Rockaway, New York. This installation cost $\$ 109,750$ and received an incentive of $\$ 23,296$ (although as of $12 / 15 / 2008$, the final incentive invoice had not yet been submitted). [34]

\subsubsection{State Rebate Example: Corvallis, Oregon}

One federal PV project was funded and completed at an U.S. Environmental Protection Agency (EPA) building in Corvallis, Oregon. The system is $9 \mathrm{~kW}$ and had an initial cost of $\$ 74,900$. However, the project received the maximum commercial incentive of $\$ 15,000$ from the Energy Trust of Oregon, Inc, thereby lowering the total costs for the installation to $\$ 59,000$. [35] The Energy Trust is a state-mandated non-profit corporation and is funded by a 3\% "public purposes charge" included on energy customer bills. This Trust, together with the Oregon Public Utilities Commission (OPUC), guides the Energy Trust's electric energy programs.

\subsubsection{State Rebate Example: U.S. Postal Service Processing and Distribution Center, California.}

The USPS West Sacramento Processing \& Distribution Center installed an on-site 403-kW PV solar system in September 2004. The 2,120 photovoltaic panels provided by PowerLight Corporation (now SunPower) cover a surface area of 28,000 square feet. The array is mounted 
on a parking lot carport that provides shade for 180 vehicles. The PV carport system was part of a larger energy retrofit by the USPS, which also included energy-efficient measures for lighting, heating, cooling, ventilation, air compressors, and energy-management control systems. The result of the entire energy project was a reduction in energy consumption of more than $33 \%$. [36] The cost of the project was about $\$ 6.2$ million; of that, $\$ 1.6$ million (about $26 \%$ ) was covered by the Pacific Gas \& Electric Company's Self Generation Incentive Program, and \$250,000 came from Standard Performance Contracting and Express Efficiency programs. [37] The remaining cost was financed through a Northern California Shared Energy Savings (SES) contract with Chevron Energy Solutions (subsidiary of ChevronTexaco). The USPS created the SES, which basically is a version of an ESPC contract (discussed in Section 5), in part because the USPS is not governed by the Federal Acquisition Regulations (FAR) (described in greater detail in Appendix C). By reducing the annual electricity purchases for the Processing \& Distribution Center by $\$ 615,000$, the entire project was estimated to pay for itself in 10 years through utilitybill savings. [38]

Overall, SBC funds provide an important source of funding for public-sector PV. Certain programs provide across-the-board incentives whereas others focus on specific sectors. Some provide up-front grants and rebates and others create low-interest loan funds. In this sense no two programs are exactly the same. These incentives can be important for helping federal agencies achieve the required payback on a PV system and receive higher-level approval for the project. 


\section{Photovoltaic Cost Savings and System Revenues}

A PV system installed on federal property for a federal agency might generate a stream of cost savings and revenues which contribute to repaying the initial capital cost, installation, operation, and maintenance of the system. This section examines these savings and revenues and identifies the situations in which they contribute to the economic benefits of a federal PV project.

\subsection{Electricity Cost Savings}

A PV system located on a customer's site typically is located "behind-the-meter" and therefore produces electricity that offsets retail electricity purchased from the local utility, or load-serving entity (LSE). ${ }^{17}$ As shown in Figure 3, the on-site generation is fed directly to the customer for its use. The advantage is that generation produced behind-the-meter ultimately reduces the electricity required from the customer's local utility, and thus the utility electricity bill.

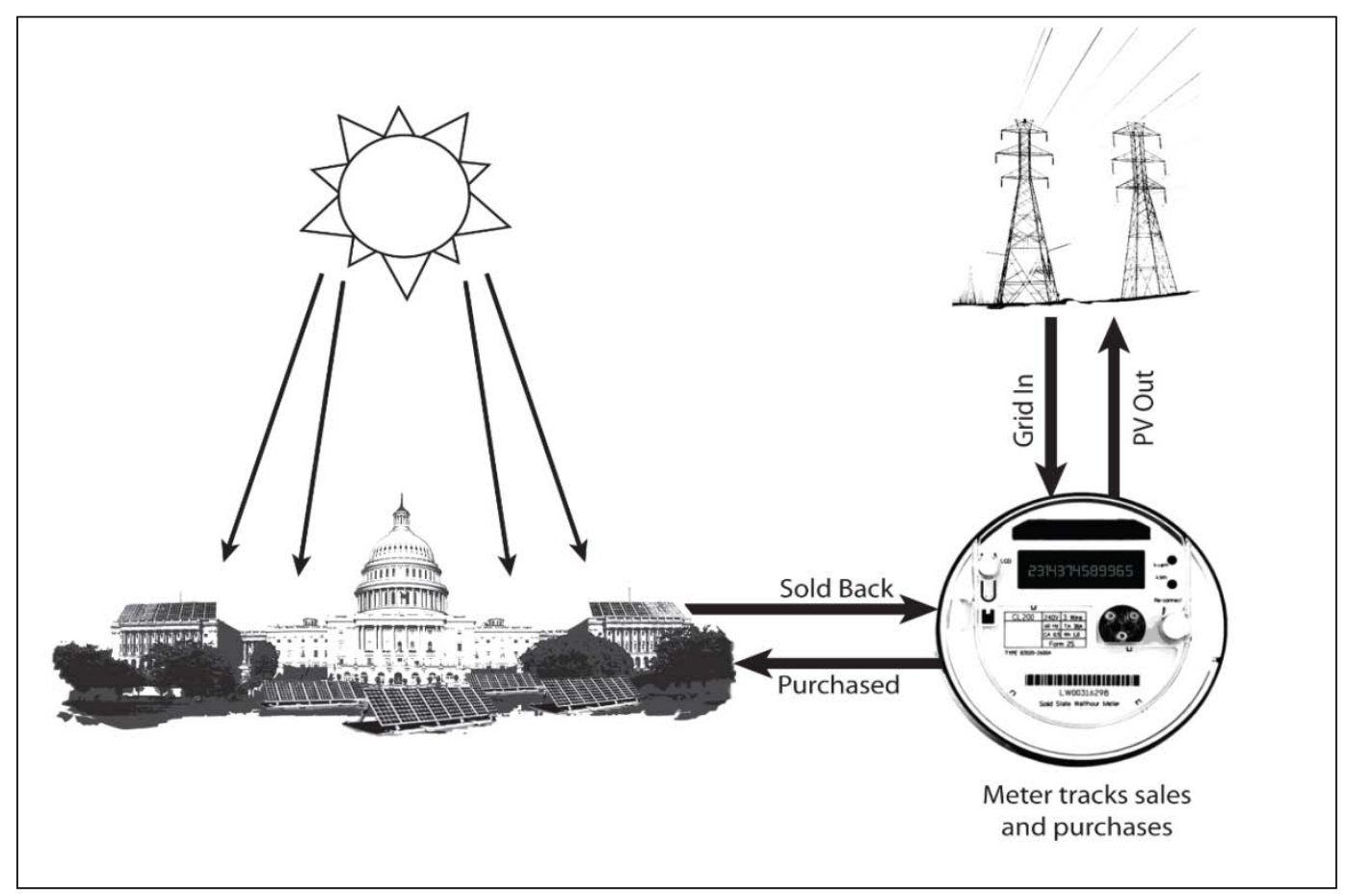

Figure 3. On-site generation and net metering

The actual retail rate avoided depends on the geographic location and season, and could depend on the time of day (for customers with time-of-use rates). As shown in Figure 4, during August of 2008, retail electricity sold to commercial users in the continental United States averaged between $\$ 0.08 / \mathrm{kWh}$ and $\$ 0.21 / \mathrm{kWh}$. Federal agencies often can negotiate lower rates, however - particularly at large sites having multiple operations - thanks to the high level of demand from their LSE. Therefore, even though the avoided electricity cost savings still exists, it

\footnotetext{
${ }^{17}$ A load-serving entity includes: investor-owned utilities in regulated electricity markets; default/standard offer utilities in restructured electricity markets (or deregulated generation markets); and competitive retail electricity suppliers in restructured electricity markets.
} 
usually is less for a federal agency than for a typical commercial customer. Even so, the pursuit of lower electricity bills can be a factor in the decision to pursue a federal-sector PV system.

In the absence of other incentives it is unlikely that simply offsetting a percentage of a facility's retail electricity purchases with PV-generated electricity will be sufficient to make the economic case for solar energy, given the high up-front capital costs. As a result, additional revenue streams - such as the sale of renewable energy attributes and other cash incentives - are critical to making a project economically attractive. This is explored further in the analysis of a federal system found in Section 6, as are the relative contribution of various cash and tax incentives and rate savings.

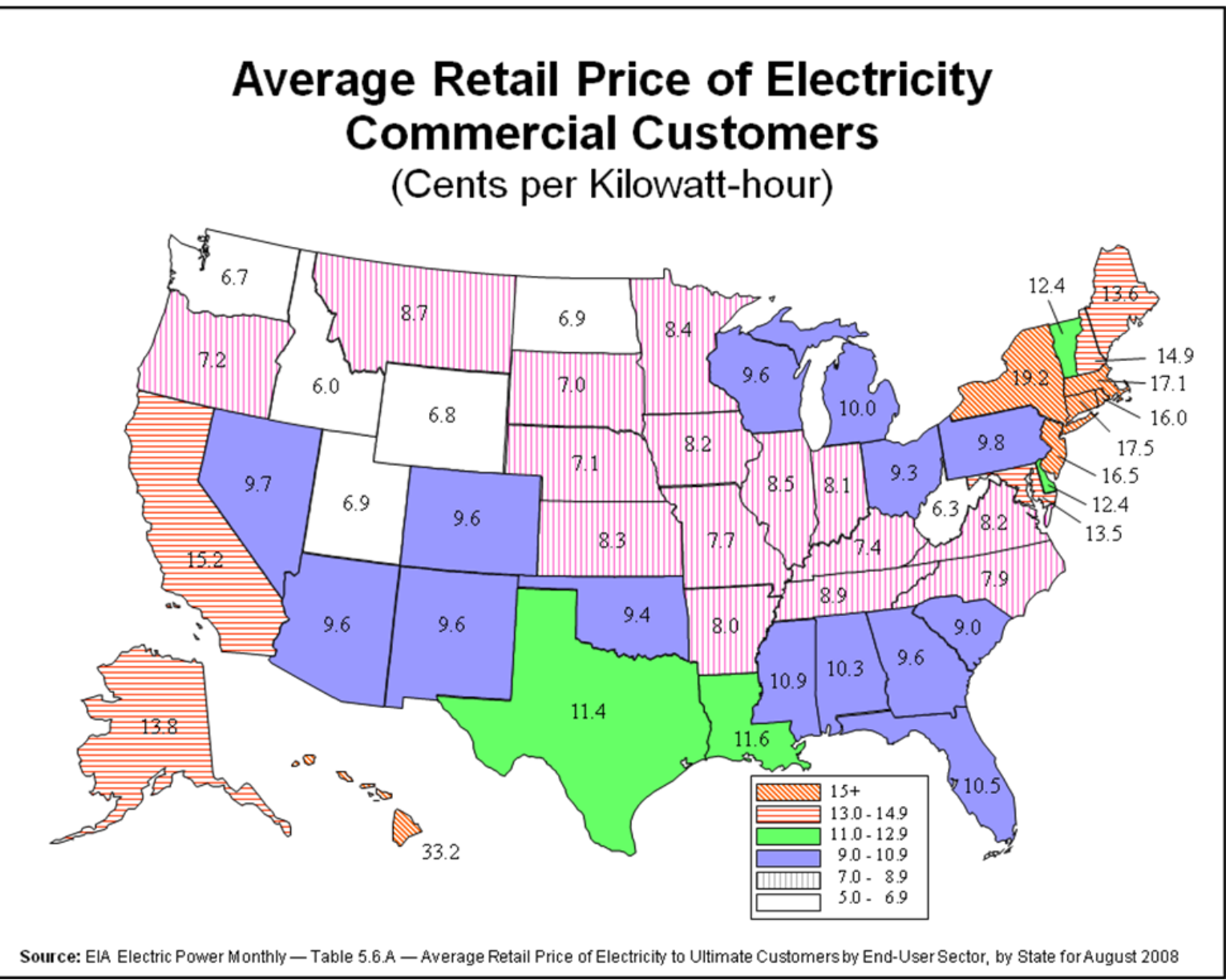

Figure 4. Retail price of electricity for commercial customers averaged for August 2008 (in $\phi / k W h$ )

\subsection{Net Metering Revenues}

In addition to offsetting electricity purchases from the utility, the majority of U.S. states allow customers to net meter, although not all states or utilities explicitly allow federal agencies to net meter. ${ }^{18}$ Net metering is the policy in which a customer with on-site generation is allowed to

\footnotetext{
${ }^{18}$ According to the Database for State Renewable and Efficiency Incentives (www.dsireusa.org), these include Arizona Public Service (Arizona), Arkansas, Connecticut, Delaware, Florida, Orlando Utilities Commission
} 
receive credit on a utility bill for any excess renewable power that is not used on-site and instead is sent into the utility's system. ${ }^{19}$ During times of excess generation, the utility meter is allowed to spin backwards. The amount the utility credit differs by state and utility, and depends on how much excess generation exists. Depending on the state, the utility can credit either the retail rate (the highest rate, as it includes transmission and distribution), the utility's avoided generation cost, or the utility's wholesale generation rate. Net metering also can enable excess generation in any given month to be carried over to the next billing month for up to a year. At that time, the utility either can pay for any outstanding credits or can reset the amount to zero with no payment to the customer, depending on the state rules.

The benefits of net metering only can be recognized at those points in time when the PV system output is greater than the customer's demand. Most federal sites are large and have significant electricity demand, therefore there are very few federal examples of net metering playing a role in a PV project. For most federal facilities that have pursued PV, net metering never comes into play because the PV system's power is fully absorbed behind the meter and no excess is sent into the utility system. Net metering, however, has the potential to support PV projects at smaller federal facilities and always should be considered in the planning phase of a PV project.

Some states do not have net metering rules or regulations. Rather than having the meter spin backwards, the customer usually is required to install a second meter (which the customer must pay for). The utility might or might not pay for excess generation — at either the avoided or wholesale generation rate. Government entities that wish to learn more about net metering in their state should access the Database of State Incentives for Renewables and Efficiency (www.dsireusa.org). A breakdown of states that offer net metering to the federal government is included in Appendix B.

\subsection{Solar REC Revenue}

Solar renewable energy credits increasingly are critical for structuring the financing of new PV projects. This section explains why RECs were developed, how they can be used in the marketplace, and the importance of SRECs in financing solar installations.

\subsubsection{RECs Overview and Background}

Renewable energy credits ${ }^{20}$ have become the dominant mechanism for compliance with mandatory RPS policies and voluntary green power purchases. These credits are tradable commodities - separate from the electricity produced - that bundle the non-electric "attributes" of renewable generation. Because they are unbundled from the electricity, RECs are not subject to transmission constraints (one of their main benefits). One REC typically represents the attributes of 1 megawatt-hour (MWh) of renewable electricity generation. The definition of "attributes" can vary across contracts, but likely will include any future carbon trading credits, emission reduction credits, emission allowances, and other non-electricity attributes. To receive credit toward meeting federally mandated renewable energy goals, the REC must include all environmental attributes.

(Florida), Hawaii, Rocky Mountain Power (Idaho), Illinois, Maryland, Massachusetts, Michigan, Missouri, North Carolina, Oregon, Pennsylvania, Utah, and Vermont.

${ }^{19}$ For more information, see "State Energy Alternatives: Net Metering," U.S. Department of Energy Web site, EERE State Activities and Partnerships, at http://www.eere.energy.gov/states/alternatives/net_metering.cfm.

${ }^{20}$ Also called RECs, tradable renewable certificates, or green tags. 
Once the REC is separated from the underlying electricity and sold to another party, claims to the attributes only can be made by the REC owner, and not by the electricity owner or the project owner. For example, the host of a solar PV system is not able to claim to be using "green power" if the RECs generated by the project are sold to another entity. This concept is explored in the third-party ownership model discussion, Section 5.2.

RECs are currently used by LSEs to demonstrate compliance with RPS requirements ("the compliance market"), and by green power marketers and utilities to supply renewable energy products to end-use customers who voluntarily purchase RECs ("the voluntary market"). The RPS is a state-level mechanism, which requires the LSEs in a given state to meet a certain percentage of customer electricity demand using renewable energy sources. When an LSE is required to meet a certain level of electricity demand with renewable energy as part of a RPS, RECs typically, but not always, are used to demonstrate compliance with the associated mandate. Exceptions include Arizona, California, Hawaii, and Iowa, where environmental attributes must be sold bundled with the underlying power. California currently is considering allowing the use of tradable RECs for RPS. ${ }^{21}$ The manner in which RECs are defined and treated in RPS policies varies by state and region.

Additionally, RECs are becoming the dominant mechanism for marketing renewable power into the voluntary market.[39] When companies like Intel [40] or Pepsico [41] announce that they are offsetting a percentage of electricity use with renewable energy, more often than not, the companies have purchased RECs in the voluntary market rather than installing wind turbines or PV systems on-site. To put these two large purchases into context, the Intel purchase of 1.3 billion $\mathrm{kWh}$ equates to one year of generation from $450 \mathrm{MW}$ of wind (33\% capacity factor), and the Pepsico purchase of 1.1 billion $\mathrm{kWh}$ equates to the generation from approximately 150 MW of baseload landfill gas or biomass ( $85 \%$ capacity factor). ${ }^{22}$ The advantage of RECs is that corporations and government agencies can support renewable energy without having to develop or support their own project, allowing them to focus on their core business. And because RECs are not subject to transmission constraints, voluntary green power customers can purchase RECs from a variety of projects from across the country to match some or all of their electricity demand. Voluntary RECs are created by entities that are producing renewable power beyond what is needed to demonstrate legal compliance with RPS requirements or by renewable energy generators that are not located in or near markets with RPS policies.

The value of a REC depends on a number of factors, including whether it is sold into a compliance or voluntary market, where in the U.S. the REC is sold, whether there is a shortage of RECs, the level of penalties in compliance markets, and whether the REC was derived from a solar resource. Table 5 shows the different values of RECs, depending on these factors. As shown in the table, RECs used for RPS compliance have significantly more value than RECs in the voluntary market. However, in both cases, SRECs have higher value than generic RECs. Finally, REC values are highest in markets with a supply shortage.

\footnotetext{
${ }^{21}$ For more information, please see the California Public Utility Commission Web site: http://www.cpuc.ca.gov/ PUC/energy/Renewables, and the specific docket Web site: http://www.cpuc.ca.gov/PUC/energy/Renewables/ hot/070824recworkshop.htm.

${ }^{22}$ Note that, in reality, the two purchases by Intel and Pepsico come from a variety of renewable resources, such as geothermal, wind, solar, biomass, and potentially others. A simplifying assumption about technologies and capacity factors was made to put these large purchases into context.
} 
Table 5. REC and SREC Prices in Voluntary and Compliance Markets

\begin{tabular}{|lll|}
\hline & RECs & Solar RECs \\
Voluntary & $\$ 1-3 / \mathrm{MWh}$ & $\$ 5-10 / \mathrm{MWh}$ \\
\hline RPS & \$1-35/MWh & \$205-375/MWh \\
\hline RPS (shortage) & \$46-56/MWh & \$660-675/MWh \\
\hline
\end{tabular}

Sources: Clear Energy, Evolution Markets, NJ Clean Energy

Program, NREL, Spectrometer, Xcel

Updated January 2009

\subsubsection{SREC Revenue}

Solar renewable energy credits are a separate commodity in most REC markets because their value is greater than that of other RECs. This is true for a variety of reasons. SRECs have the most value in markets having a separate solar tier in their RPS (also called a "carve-out" or a "set-aside") and a high penalty price for non-compliance above what the owner/developer needs to make project economics work. Several states encourage solar or distributed generation (DG) through a specific solar/DG tier in the RPS. The goals of creating such a tier include increased deployment of solar and DG technologies, diversified electricity generation, and in-state economic development benefits. By separating solar and DG into their own tier, the RPS protects these higher-cost technologies from competing against more cost-competitive, renewable technologies like wind and landfill gas. The penalty price for non-compliance of a solar set aside often is greater than for standard RPS compliance. Increased penalties encourage LSEs to support new development, by accounting for the greater cost of solar and the lack of economies of scale with smaller projects. The SRECs also tend to be desirable in the voluntary market, and customers are willing to pay much more for SRECs than for wind or biomass RECs, as shown in Table 5 .

Examples of the significant SREC project revenues created from solar RPS set-asides can be found in Colorado and New Jersey. Prior to summer 2008, SREC prices ranged from \$160/MWh to $\$ 265 / \mathrm{MWh}$ in these two states. ${ }^{23}$ During summer 2008, SREC prices increased to between $\$ 50$ and $\$ 310 / \mathrm{MWh}$ for the 2008 compliance year, as shown in Table 5. At the end of 2008, SREC values in New Jersey increased because the state increased its SREC cap from $\$ 300 / \mathrm{MWh}$ to $\$ 711 / \mathrm{MWh}$ for the 2009 compliance year (which started in July, 2008). [42] This is the highest solar price cap in the nation and will ramp down over time. A high SREC price cap, in conjunction with phasing out up-front rebates, led to significantly greater SREC prices in the first couple months of trading. As shown in the table, NJ SREC prices have exceeded $\$ 600 / \mathrm{MWh}$.

There are 18 RPS programs that include solar or DG RPS set-asides. The set-asides are included in programs in Arizona, Colorado, Delaware, Maryland, Massachusetts, Michigan, Missouri, Nevada, New Hampshire, New Jersey, New Mexico, New York, North Carolina, Ohio, Pennsylvania, Texas, Washington, and Washington DC.

\footnotetext{
${ }^{23}$ NREL estimate based on Xcel Energy's "2008 Renewable Energy Standard Compliance Plan," Section 5Acquisition Plans, available at http://www.xcelenergy.com/docs/Section5-Acquisition_Plans_Final.pdf; and New Jersey's Clean Energy Program "SREC Pricing: SREC Trading Statistics," available at http://www.njcleanenergy.com/renewable-energy/programs/solar-renewable-energy-certificates-srec/pricing/pricing.
} 
As shown in Figure 5, of these:

- Fifteen states and the District of Columbia specify a certain quantity or percentage of the RPS must be met with solar resources;

- Three RPS programs have set-asides for customer-sited or distributed systems, which tend to favor solar;

- Six states and Washington, DC, offer extra credit for either solar or distributed generation; and

- A few states have more than one of these provisions.

Collectively these provisions could result in the installation of thousands of megawatts of solar electric capacity by 2025 . If it is met, for example, then Maryland's solar set-aside is expected to result in 1,500 MW of new solar capacity. [43] An April 2008 report by the Lawrence Berkeley National Laboratory estimated that if compliance is achieved with the various state-level solar RPS set-asides (in place as of early 2008), it could result in roughly 6,700 MW of additional solar capacity by 2025. [44] If the Ohio and Missouri solar set-asides are included, then this total jumps to more than 7,600 MW. [45]

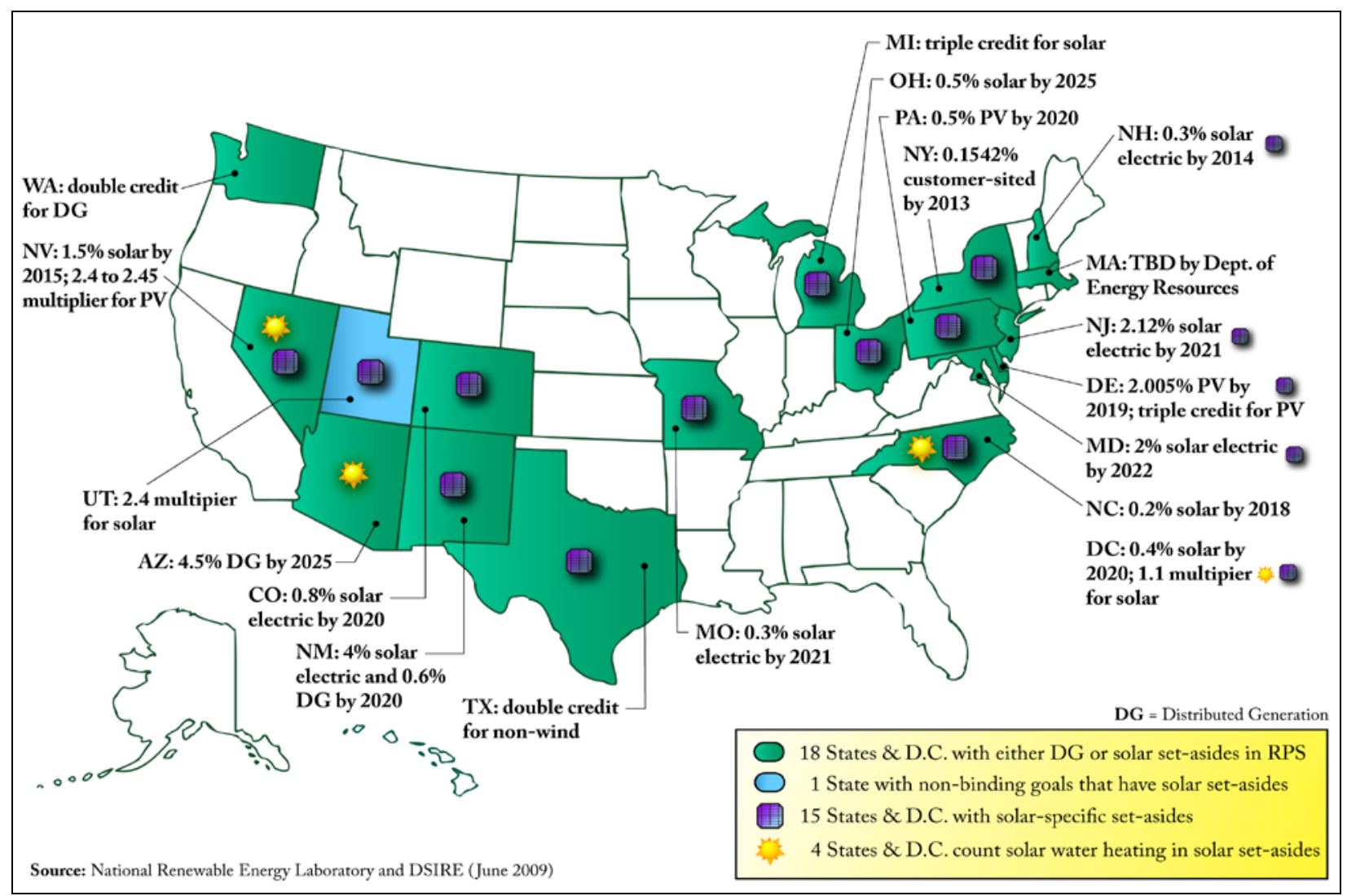

Figure 5. Solar/distributed generation provisions in state RPS policies

SRECs can be a very important revenue stream for developing new projects. Federal agencies could decide to sell the SRECs to nearby LSEs that must comply with solar set-asides in RPS 
programs to secure a significant payment; the SREC cash-flow stream very well could determine whether a particular project is economically viable. According to 3 Phases Energy Services, SREC cash flows in Colorado account for roughly $40 \%$ of total project cash flows. [46] Personal interviews with developers structuring deals have noted that SRECs can account for $40 \%$ to $80 \%$ of the total revenue stream of a project, in particular states.[47] As explained above, however, not every state has SREC prices that are high enough to provide solar projects with this type of support.

If the SRECs of a federal project are sold (to parties in either voluntary or mandatory markets), however, then the site host also sells the right to claim that it uses green power, unless replacement RECs are purchased. The differing state SREC prices in the mandatory and voluntary markets present a unique opportunity for federal agencies pursing PV projects. State RPS requirements usually tie the solar or distributed generation requirement to renewable energy developed within the respective state. Conversely, the Guidance (noted in Section 1.3) for federal renewable energy procurement lets agencies use RECs from anywhere. Therefore, federal agencies can take advantage of price differentials caused by geography and varying state regulations. However, as mentioned earlier, RECs will not be allowed towards federal compliance starting in FY 2013.

In states without solar rebates or a specific solar RPS carve-out, it can be very difficult to structure economically viable solar projects that provide payback periods acceptable to public entities, given the capital costs involved. This explains why most of the PV installations are located in states such as California, Colorado, and New Jersey. California has a statewide solar rebate program although it does not have an RPS with a specific solar tier. In Colorado, Xcel Energy - the state's largest utility - administers a program to purchase SRECs from end-users as part of its compliance activities with the solar tier of the state's RPS. Additionally, the Xcel program also includes an up-front solar rebate. New Jersey has a high SREC penalty, which encourages new PV installations in conjunction with the sale of SRECs to the local utility. Note that, although each program is structured differently, they all have been successful.

\subsubsection{SRECs Example: General Services Administration Project, Colorado}

A 1.18-MW PV system was completed at the Denver Federal Center (DFC) in Lakewood, Colorado, in January 2008. The U.S. General Services Administration (GSA) ${ }^{24}$ Rocky Mountain Region utilized 6 acres to install 6,192 PV panels on the grounds of the DFC. The system is expected to produce 1.525 million kWh annually and it is connected to the DFC's substation, so no additional transmission is required. [48] Approximately 10\% of the DFC's peak electricity (and 3\% of annual electricity) will be offset by the PV system, which roughly is equivalent to powering 145 homes. [49]

GSA awarded the $\$ 6.9$ million contract to SunEdison for design and construction of the project. [50] In addition to GSA headquarter funding, the financing of this project was made possible through three main mechanisms: a congressional appropriation; a utility rebate resultant from the state's RPS policy (which the state calls a renewable energy standard); and the sale of SRECs. The Colorado RPS includes a solar set-aside that requires a certain amount of solar

\footnotetext{
${ }^{24}$ The GSA owns and manages federal buildings and land, therefore it has participated in several of the solar project examples explored in this report.
} 
power be generated at customer sites. To meet this solar set-aside requirement, Xcel Energy developed the Solar*Rewards program and periodically issues requests for proposals (RFP) for projects ranging in size from $100 \mathrm{~kW}$ to $2 \mathrm{MW} .{ }^{25}$ Project developers bid a solar REC price based on the project's economics. GSA was successful in its bid for the DFC, and as a result received a $\$ 200,000$ up-front rebate. [51] The also array generates an estimated $\$ 340,000$ per year through revenue produced by the sale of SRECs to Xcel Energy. [52] The SRECs are used by the utility to demonstrate compliance with Colorado's renewable energy standard. The PV system at the DFC contributes to the federal renewable energy mandate for GSA, because replacement voluntary RECs are being purchased to offset the solar RECs sold to Xcel. In addition to the utility rebate and monthly payment for SRECs, the GSA also received a federal appropriation to cover the remaining costs of this project.

As described in this section, on-site PV generation can lead to cost savings and decreased utility bills by reducing electricity use (i.e., fewer $\mathrm{kWh}$ demand) and lowering demand charges (in some cases). Where eligible, federal agencies can net meter excess output from on-site solar projects, particularly if projects are sized to meet the load at a particular federal site. This creates additional savings from the utility electricity bill. Potential revenues from SRECs in states with solar RPS set-asides can contribute $40 \%$ to $80 \%$ towards a project's cost. If replacement RECs are purchased, then the federal agency still can count the system output towards federal renewable energy mandates.

\footnotetext{
${ }^{25}$ The Solar*Rewards program also includes separate programs for projects that are $0.5 \mathrm{~kW}$ to $10 \mathrm{~kW}$ (receive an up-front $\$ 4.50 / \mathrm{kW}$ incentive) and for projects that are $10.1 \mathrm{~kW}$ to $100 \mathrm{~kW}$ ( $\$ 2 / \mathrm{W}$ up-front rebate, plus monthly payment of $\$ 115 / \mathrm{MWh}$, based on actual production to buy the SRECs).
} 


\section{Federal and State Tax Credits}

The recently enacted Recovery Act and the Emergency Economic Stabilization Act of 2008 (EESA 2008) provide unprecedented federal support for renewable energy development in the United States through a wide array of new or expanded tax credits, loan guarantees, grants, and appropriations.[53] These various mechanisms are intended to stimulate government and private enterprise investment in renewable energy facilities and should greatly improve the economics of PV development by federal agencies.

In recent years, the third-party ownership/PPA model (described in Section 5) has emerged as a mechanism whereby renewable projects on government property can benefit from tax incentives offered by the federal and state governments. These tax incentives provide tremendous value to the system owner, and can be passed on to the public host. The federal investment tax credit (ITC) and the Modified Accelerated Cost-Recovery System (MACRS) (or accelerated depreciation), can provide slightly more than $50 \%$ of the installed cost of a PV system. [54] This can dramatically alter the economic viability of installing solar. State tax incentives also provide benefits to tax-paying entities with operations (and therefore a tax base) in those states. The value of these incentives can be passed on to public entities. Developers try to set the predetermined electricity price established in the PPA at or below the utility's retail rate in the first year. The tax credits are a primary reason why this is possible in limited areas of the country. This section explains the two primary federal tax incentives for solar - the ITC and MACRSand also describes several state tax incentives that can improve PV system economics.

\subsection{Investment Tax Credit}

For commercial entities, the federal government currently offers a $30 \%$ investment tax credit (ITC) to partially offset the up-front installed cost of a PV system. ${ }^{26} \mathrm{~A}$ PV system with an installed cost of $\$ 1$ million, for example, will qualify for a $\$ 300,000$ tax credit for the year in which it goes into commercial operation. This tax credit was extended through December 2016 with the passing of EESA 2008. In addition to the extension, several details were adjusted within the ITC that could help new investors participate in solar projects. ${ }^{27}$ The Recovery Act expanded the usefulness of the ITC by allowing taxable entities to take the ITC in the form of a cash grant. Importantly, taking the ITC in the form of a grant expands the eligibility for the program because otherwise it is beneficial only to companies with tax liabilities. The U.S. Department of Treasury notes that the application process for accepting the ITC via a cash grant opens in July 2009. [55] The effectiveness of the program will depend on the speed of this application process and the clarity of some of the implementation details.

Prior to enactment of the EESA 2008, utilities were not able to directly take advantage of the ITC; if an investor-owned utility (IOU) wanted to support solar, it had to either sign a PPA or use a third-party ownership/PPA arrangement. Now IOUs can choose to own their own PV projects and take the ITC directly, if desired. Many utilities, however, still will want to partner with third-party developers to take advantage of the developers' extensive solar development and operations expertise. Overall, the ITC extension is a crucial "demand-signal" for the industry to

\footnotetext{
${ }^{26}$ See Section 48 (a) (3) (Investment Credit: Energy Credit) in the IRS tax code.

${ }^{27}$ Although not relevant to federal agencies, residential applicants for the ITC previously only could receive up to $\$ 2,000$ for the $30 \%$ credit; as of January 2009 they can receive an uncapped 30\% credit.
} 
continue to build and invest in PV development. The expansion of ITC eligibility means there also could be a wider variety of potential partners for federal projects - including utilities and other corporations.

The rules associated with the ITC are complex and an interested party should have a tax lawyer review the application of the ITC to federal projects. Certain incentives can reduce the ITC's value and also can impact the depreciable basis of the underlying asset. Although the passing of the EES Act of 2008 has and will continue to alter some of the details of the ITC, the recently updated version of the Solar Energy Industry Association's (SEIA) 2008 Guide to Federal Tax Incentives for Solar Energy: Version 2.0 provides good background information and guidance. $[56]^{28}$

\subsection{Modified Accelerated Cost-Recovery System and Bonus Depreciation}

As defined by the IRS, "depreciation is an income tax deduction that allows a taxpayer to recover the cost or other basis of certain property. It is an annual allowance for the wear and tear, deterioration, or obsolescence of the property." [57] Depreciation schedules can range from 3 to 50 years, depending on the asset. [58] It is a non-cash charge recorded as a depreciation expense for tax purposes, and most property today is depreciated using Modified Accelerated CostRecovery System (MACRS). [59] The IRS permits commercial owners of PV systems (and most renewable systems) to use a five-year MACRS schedule.

Depreciation reduces an entity's taxable income and subsequently its tax burden. The shorter the depreciation schedule, the greater the percentage of the asset that can be depreciated each year. So, in the case of PV, five-year MACRS is more advantageous than longer depreciation schedules because shorter schedules enable businesses to accelerate the tax benefits of depreciating a particular asset.

The Economic Stimulus Act of 2008 (ESA08) contains bonus depreciation for qualifying assets placed in service in the 2008 calendar year (and only that year) [60]. Renewable energy installations, including PV systems, can qualify for this bonus depreciation if certain criteria are met. Instead of the standard five-year MACRS schedule described above, under the ESA08 50\% of the installed cost of the PV system can be depreciated in the first year, with the remaining $50 \%$ to be depreciated using the original schedule. By accelerating the amount of depreciation in the first year, tax benefits accrue more rapidly to investors, thus improving the return characteristics of the project. The ESA08 did not change the requirement that the depreciable basis of the underlying asset be reduced by $50 \%$ of the federal investment tax credit.

\subsection{Appropriations to Federal Agencies}

The Recovery Act appropriated $\$ 5.55$ billion to be deposited into the Federal Buildings Fund as administered by the General Services Administration (GSA) for expenditures to construct, repair, and make alterations on federal buildings to increase energy efficiency, including installing solar energy equipment. [61] Of the $\$ 5.55$ billion appropriated, $\$ 4.5$ billion is to be available for measures necessary to convert GSA facilities to high-performance green buildings - which could include PV - to reduce building energy consumption. GSA estimates that $75 \%$ of the anticipated projects will include a solar component. [62] The Recovery Act intends for these funds to be

\footnotetext{
${ }^{28}$ To purchase this publication, visit: http://seia.org/cs/tax_manual_non_members.
} 
issued quickly by specifying that not less than $\$ 5.0$ billion is to be obligated by September 30 , 2010. The Recovery Act also appropriates $\$ 1$ billion for non-recurring maintenance on Veterans Affairs facilities-including energy projects.

\subsection{State Tax Incentives}

Individual states have a number of mechanisms at their disposal to support the development of renewable energy within their jurisdictions. State tax-incentive programs are used to encourage and facilitate the use of renewable energy within the state. These mechanisms create additional value for corporate entities that purchase and own PV systems. According to DSIRE, 46 states offer some form of local tax relief to encourage renewable energy development. [63] Various tax credits, exemptions, or deductions could be offered at any point in the value chain-from manufacturing to purchasing and installing. Although the federal government might not always be directly eligible for these incentives, there might be ways for government agencies to benefit, particularly through the third-party ownership/PPA model of project financing. Below is a brief summary of the primary state tax incentives offered across the United States.

\subsubsection{Corporate Tax Incentives}

As of January 2009, 24 states offer corporate tax incentives for renewable energy generation. Corporate incentives can include state tax credits ranging from 10\% to 35\% [64] as well as simple deductions or exemptions. [65] The incentives are offered to corporations to cover equipment costs or other related material expenses (i.e., not labor) for the renewable energy investment. Often these credits are applicable only when a specified minimum dollar amount is invested. [66] Although most state corporate tax incentives exclude the federal government as a direct recipient, some do allow a third party (e.g., financiers, installers, manufacturers) to be eligible, which could indirectly benefit the federal government.

\subsubsection{Sales Tax Incentive}

Twenty-four states also offer some form of exemption from the state sales tax for the purchase of a renewable energy system or related equipment. [67]

\subsubsection{Production Tax Incentives}

Production tax incentives usually come in the form of annual payments made over a period of years for the actual electricity (kWh) produced by a renewable energy system. [68] Production incentive payments, currently offered by seven states and more than a dozen utilities, can motivate proper operations and maintenance of a PV system because it is based on actual generation of the system over time.

\subsubsection{Federal Agency Use of State Tax Credit: Oregon Business Energy Tax Credit}

Although federal agencies do not pay state taxes, there are some innovative ways that state tax credits can benefit federal PV projects. The Oregon Business Energy Tax Credit (BETC) is noteworthy given its relevance to federal agencies. The BETC is a state income-tax credit that provides tax credits totaling up to $50 \%$ of the installed costs of a renewable energy system. For $\mathrm{PV}$, the maximum eligible credit currently is capped at $\$ 20$ million for manufacturers of renewable energy equipment; and $\$ 10$ million for all other projects. [69] Once the PV system is operational and has been completely paid for, the tax-paying entity applies the tax credit pro rata (or equally) over 5 years to lower its state income-tax bill. Those with eligible project costs of 
$\$ 20,000$ or less can take the tax credit in one year. [70] In recognition of the non-tax-paying status of government agencies and nonprofits the Oregon Department of Energy created a "PassThrough Option." It permits a federal agency to sell the present value of its tax credit to a taxpaying entity and use the proceeds to defray the cost of its PV project. [71] Although this mechanism has not yet been used to support solar on a federal government building or on federal land, federal projects are eligible and it has been used for state and local government buildings. [72] In 2002, for example, the North Santiam School District in Oregon's Central Cascade Mountains sold its tax credits to the Nike Corporation and received \$129,000 to assist with the capital costs of its energy efficiency upgrades. [73]

As described in this section, federal and state tax incentives can significantly improve the economics of a PV project. Combined, the ITC and MACRS can cover approximately half of the installed cost of a PV system. State tax incentives also can play an important role in reducing the total cash needed to install PV - particularly in Oregon, where the state tax credit can be transferred from a federal agency to a corporation. The next section describes the third-party ownership/PPA model in detail, to explain the structure of how federal agencies can benefit from tax incentives for PV systems deployed on government property. 


\section{Federal PV Financing Models}

Unless a PV system is paid for in cash, structuring the financing of PV systems on federal land and buildings can be complex. As described above, there are significant federal tax incentives that can substantially improve PV project economics. Market participants have determined how to incorporate these incentives into projects deployed on federal property in the last few years. This section explores the different ways that PV can be financed; the importance of incorporating energy efficiency into a project; how federal agencies are using the third-party ownership/PPA model to secure PV on their land; and how the energy savings performance contract/utility energy service(s) contract (ESPC/UESC) model is being used, sometimes in combination with the third-party ownership/PPA model as an Energy Services Agreement.

\subsection{Energy Efficiency and PV}

Energy efficiency can be a critical component for the deployment of PV on federal property. In addition to the cost savings from energy-efficiency retrofits - which can have very attractive payback periods - there are direct benefits related to the installation of a PV system. If the energy consumption of a facility is lessened as a result of energy-efficiency investments, then the PV system can offset a greater portion of the total load of the facility, or reduce the size of the PV facility (and the cost). Additionally, energy savings resulting from energy-efficiency investments can help defray the cost of owning and maintaining a PV system. In states that do not offer PV incentives to federal agencies, the bundling of energy efficiency investments with $\mathrm{PV}$ can be critical to making the economic case for moving ahead with the project.

\subsubsection{EE and PV Example: U.S. Postal Service Processing Center}

In November, 2001, the U.S Postal Service (USPS) installed a 127-kW PV system at the Marina Mail Processing Center in Marina del Rey, California. PowerLight Corporation (now SunPower) supplied 845 solar tiles to cover 15,000 square feet of the Marina Center's rooftop. In addition to providing electricity, the panels reduce the building's energy consumption by providing thermal insulation with an R-20 value. ${ }^{29}$ [74]The installation is part of a broader energy project that links to a Viron Energy Services energy-management system which enables Marina Center to achieve maximum peak-demand savings. [75] The impact of the solar installation and integration of the energy-management system was an estimated $10 \%$ reduction in peak-demand electricity consumption. [76]

The Marina Center PV project was financed through several sources. The Los Angeles Department of Water and Power offered a \$6/watt utility rebate which amounted to $\$ 683,000$ of the total cost of $\$ 1,033,000$ for the system. An additional $\$ 125,000$ came from the DOE's Federal Energy Management Program (FEMP) through a grant for distributed energy resource equipment. The remaining $\$ 225,000$, was covered by USPS energy conservation funds and ultimately will be recovered over a period of nine years (simple payback) through annual energy cost savings of $\$ 25,000$. [77]

\footnotetext{
${ }^{29}$ The ability for insulation to decrease heat transfer between a building and the outside is measured as R-value. The greater the R-value, the more efficient the insulation. Average R-values for common insulation materials ranges from 2.8 to 7.0 [79] (DOE 2001). Average U-values for windows fall between 1.20 and 0.20 , which converts to the average R-values of 0.80 to 5.0 [80].
} 


\subsection{Third-Party Ownership/Power Purchase Agreement Model}

In the public-sector PV marketplace, some federal agencies are taking advantage of the thirdparty ownership/PPA model. According to Greentech Media, in 2007, 50\% of the growth in the commercial and institutional market for solar PV in the United States was carried out using the third-party owner model, as compared to just $10 \%$ in 2006. [78] Although this is common in the private sector, the use of third-party ownership/PPA structures still is a relatively new phenomenon in the public sector.

Federal agencies are starting to see the third-party ownership/PPA model as a potential way to effectively monetize federal tax benefits, avoid paying the up-front cost of solar, more efficiently allocate public funds, and accelerate the deployment of PV. Federal agencies unable to sign PPAs that are longer than 10 years ${ }^{30}$ might be able to use a contractual intermediary, such as the Western Area Power Administration, to help reduce PV deployment costs. Examples of the third-party ownership/PPA structure in place in the federal sector are detailed below. Note that this section only addresses third-party ownership/PPA models that are separate from - and unrelated to-ESPCs; the combination is discussed in Section 5.

Instead of owning the PV system, a third-party ownership/PPA model allows a public entity to host a system that is paid for and owned by a taxable entity. The public entity enters into a longterm contract (the PPA) with a third-party to purchase the electricity generated on its property. The electricity price typically is set at or below the host's current retail rate for the first year, and then typically increases at a fixed percentage over time. The developer manages all aspects of system financing, installation, and maintenance, and bears all operating risks as illustrated in Figure 6. More details about the roles and ways that a federal agency can execute a third-party ownership PPA, including the steps that must be taken, are included in Appendix C.

The details of the roles and responsibilities of different parties for one variation of the third-party ownership/PPA model are shown in Figure 6. Benefits of the third-party ownership/PPA structure include:

Ability to monetize federal tax incentives (ITC and MACRS) through a third-party project investor, which lowers the overall cost to the federal agency;

Low/no up-front cost, burden transfers to the project developer and its investors;

Predetermined electricity price for term of contract, for the portion of load served by the PV system; typically around the customer's current retail rate in the first year. thereafter that the rates might be fixed, escalate annually, or even could go down;

Operations and maintenance responsibilities are shifted to a qualified third-party project developer; and

Path to PV system ownership; if negotiated as an option in the PPA, the federal agency can usually purchase the PV system at the fair market value, on or after year six. ${ }^{31}$

\footnotetext{
${ }^{30}$ It is important to note that as of July 2009, draft federal legislation in the U.S. House of Representatives and the U.S. Senate include a provision that would allow all federal agencies to use either 20-year or 30-year contracts (respectively) for renewable electricity procurement, according to Kevin DeGroat of Anteres Group (personal e-mail communication on July 17, 2009). Readers should check to see if this legislation was passed.

${ }^{31}$ Federal tax credits typically are fully monetized in year 6 for MACRS and year 1 for ITC.
} 


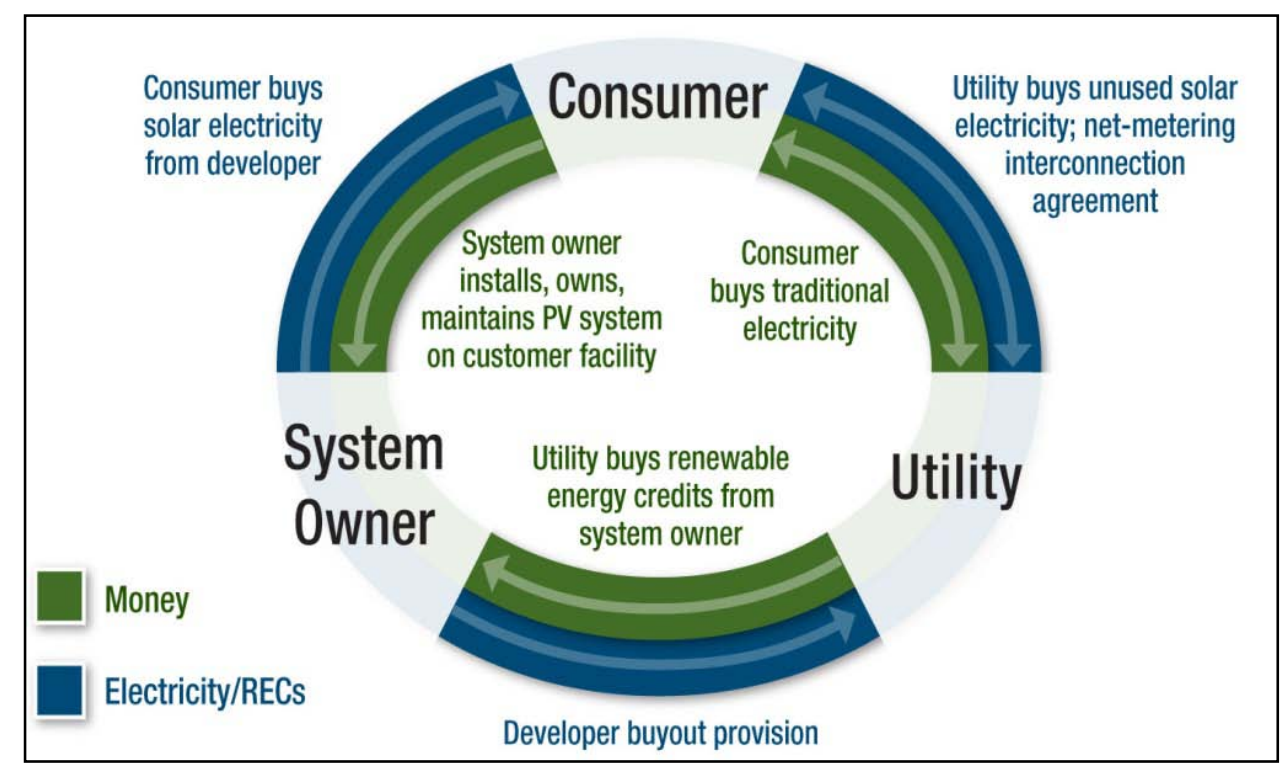

Figure 6. Contracts and cash flow in third-party ownership/PPA model

Source: Department of Energy Solar Program

Although the third-party owner model is attractive, there are some important caveats, some of which are listed below.

Renewable energy claims cannot be made if the SRECs are sold unless replacement RECs are purchased. The federal agency can state that it hosts the solar system; and if it buy cheaper replacement RECs (e.g. hydro or wind), then it can claim consumption of green (but not solar) power.

Reduced electricity expenditures might take time to manifest because the host agency still pays for the solar electricity during the PPA (although payments will be predictable and PPA prices could end up being less than utility electricity rates).

Access to the facility must be provided to the developer under a land-use agreement (lease or easement), license, or other agreement to enable the developer to maintain the system — which can pose challenges for secure or sensitive sites.

Risks and responsibilities of each party should be outlined in the RFP phase, to the extent possible. The more precisely this is done in the RFP, the less the challenge posed to all parties during contract negotiations.

Transaction costs of lawyers and other parties must be covered,

Legality concerns are starting to be raised in several states (e.g., Nevada), where there is a question about whether the third-party is illegally competing with the utilities. This topic will be explored further in a forthcoming NREL report. [81]

Current authority for federal agency/private party PPA agreements could be limited to 10 years for most federal agencies. This challenge, however, can be overcome with intermediary contract partners. This concept is discussed in Section 5.3. 


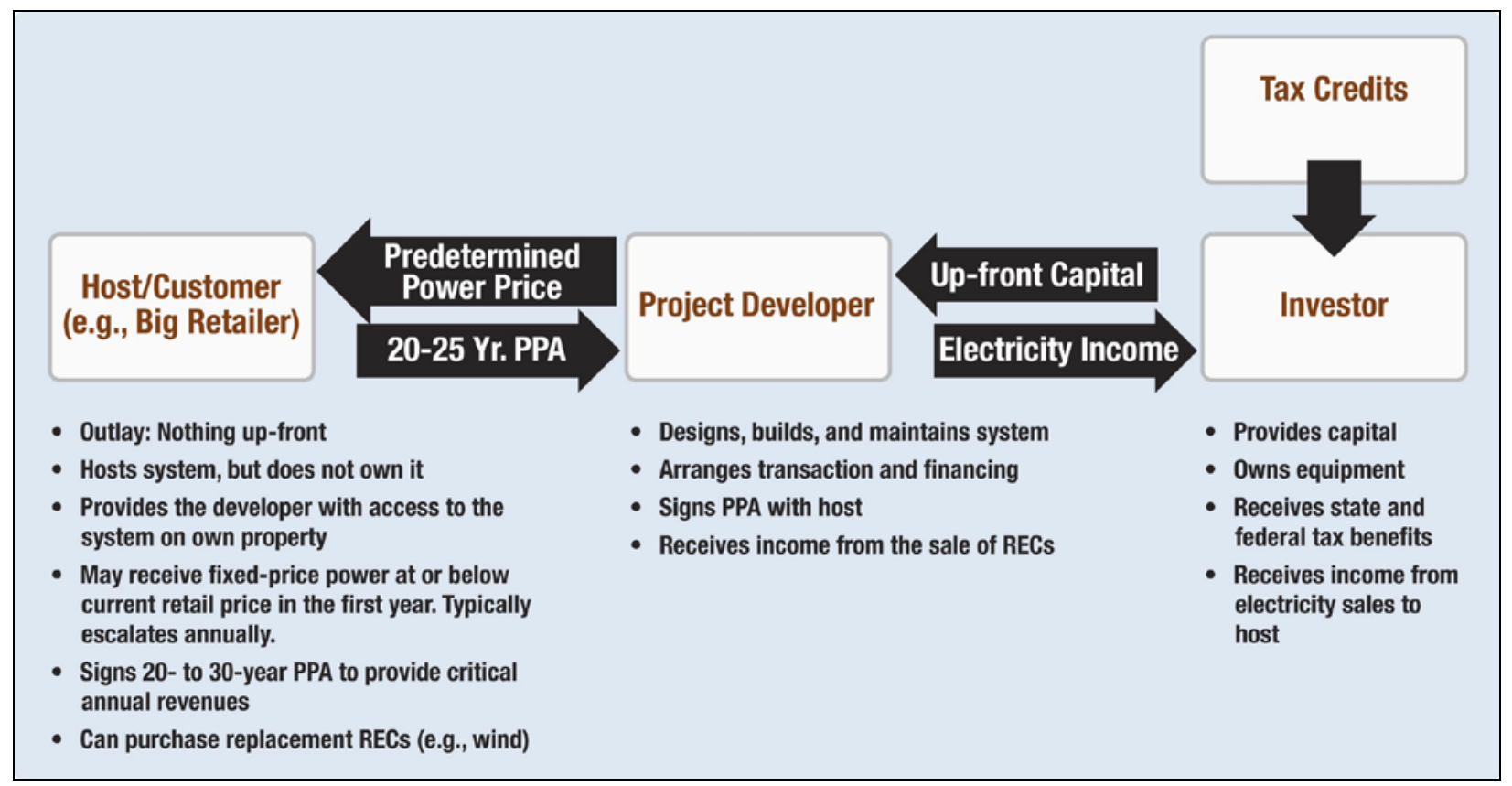

Figure 7. Third-party ownership/PPA model details (one variation)

\subsubsection{Third-Party/PPA Example: Nellis Air Force Base}

The 14-MW PV system installed at Nellis Air Force Base (Nevada) in December 2007 is the largest PV power plant in operation in North America, as of mid-2008. ${ }^{32}$ The \$100-milliondollar project utilizes approximately 70,000 panels across 140 acres, some of which is capped landfill space. [82] The array incorporates a tracking system which allows it to capture $30 \%$ more energy than standard fixed-tilt systems. [83] The system will meet $25 \%$, or 30 million $\mathrm{kWh}$, of the base's annual electricity needs. [84]

The Air Force purchases the electricity produced through a PPA. [85] MMA Renewable Ventures LLC owns and operates the PV system and is selling the generated electricity at a fixed price to Nellis for 20 years. Under the rates of the PPA, this should save Nellis base roughly $\$ 1$ million per year in energy costs. [86] Additional benefits are created through the sale of the RECs to the local utility, Nevada Power. [87] It is important to note that, because this is a PPA on federal property, the PUC deemed the federal agency to be exempt from the PPA legality issues mentioned above.

\subsubsection{Third-Party Ownership/PPA Example: GSA Federal Building, California}

The GSA installed a 506-kW PV system on the rooftop of the federal building at 2800 Cottage Way in Sacramento, California. In November 2006, GSA awarded a 10-year contract to Deliddo and Associates (dba DEERS) from Ripon, California, which partnered with Constellation Energy

\footnotetext{
${ }^{32}$ SunEdison was the winning bidder of a Duke Energy RFP in May 2008. Duke will sign a contract to purchase the output from a 16-MW PV plant that is expected to be on-line before the end of 2010. If built, this would be the largest solar PV installation in North America. For more details, see http://www.renewableenergyworld.com/ $\mathrm{rea} /$ news/story?id=52550.
} 
Projects and Services Group Inc. Installation began in the fall of 2007 and the project started to produce power on March 1, 2008. The solar system is expected to produce approximately $740 \mathrm{MWh}$ annually and is mounted using Velcro-type attachments to avoid roof penetrations. [88]

General Services Administration used modified Federal Acquisition Regulations Part 41 clauses, as well as Part 12 (Acquisition of Commercial Items), in executing the contract. [89] Any federal procurement of material or services requires that any contract must comply with procedures, terms, and conditions per applicable FAR. In this case FAR 41 applies to utility services and Part 12 applies to acquisition of generally available "off-the-shelf services or systems."[90]

Several aspects of the third-party ownership/PPA model are important in the financing of this project. Most importantly, the GSA will retain cost savings from reduced demand charges, as well as the added insulating value of the system during the 10 years of the PPA. The contract price of power is indexed to equal the energy costs under the local utility's rates (Sacramento Municipal Utility District). Second, DEERS owns the system, arranged the financing, and provides all operations and maintenance services during the term of the PPA. DEERS was granted a license for use of the federal building's roof to host the PV system. Third, approximately half of the system's cost will be covered by a utility rebate and federal tax incentives (ITC and MACRS - thanks to the participation of a third-party owner). Additionally, any net metering credits will be passed on to the contractor. DEERS retains the rights to the SRECs. [91] It should be noted that GSA is planning to purchase replacement RECs, to be able to claim credit for the renewable energy attributes lost to the contractor. Finally, DEERS also gets the incentives offered by the California Public Utilities Commission through the SelfGeneration Incentive Program, as well as other tax benefits. [92]

\subsection{PPA Contracting Intermediary: Western Area Power Administration}

Using a third-party ownership/PPA model the Western Area Power Administration, in partnership with NREL, has developed a mechanism that can help federal agencies in WAPA's service territory finance on-site renewable energy projects. Renewable energy projects with PPAs of 20 years are more financially attractive to both the hosting federal agency and the project developer. The longer the period over which the costs are amortized, the lower the levelized cost becomes. Most federal agencies have are limited to energy purchase contracts of 10 years or less. A major exception is the DOD, which has 30-year authority under 10 U.S.C. 2922a, but is subject to the approval of the Secretary of Defense [93],. WAPA can utilize its power-marketing authority to enter into contracts for longer periods, and has entered into contracts for terms of up to 20 years. ${ }^{33}$ Both Fort Carson Army Base and NREL have used WAPA's longer contracting authority for renewable energy projects installed at their sites. It is important to note that as of July 2009, draft federal legislation in the U.S. House of Representatives and the U.S. Senate include a provision that would allow all federal agencies to use either 20-year or 30-year contracts (respectively) for renewable electricity procurement, according to Kevin DeGroat of Anteres Group (personal e-mail communication on July 17,

\footnotetext{
${ }^{33}$ Authority is through three mechanisms (1) Economy Act, 31 U.S. C. 1535(b); (2) Western's Power Marketing Management Council's (PMMC) Renewable Resource Products and Services policy memo, February 2006; and (3) Renewable Resources for Federal Agencies (RRFA) Program (charter dated August 8, 2003) (Randy Manion/WAPA legal review).
} 
2009). Readers should check to see if this legislation was passed. If this were to become law, contractual intermediaries like WAPA would not be necessary.

The current process, discussed in detail in Appendix D, requires the hosting federal agency to select the renewable energy developer. WAPA participates by negotiating and executing a longterm contract with the project developer/owner (possibly with options to renew). WAPA also negotiates and executes an inter- or intra-agency agreement with the hosting federal agency/project host. WAPA's experience in this area allows it to play an advisory role in the development process; however, the hosting federal agency must lead the overall project development.

Figure 8 shows the parties involved in developing a renewable energy project, along with their associated responsibilities. As indicated, the hosting federal agency receives the benefits of the third-party ownership/PPA model; the only up-front costs are paid to WAPA for the actual expense to develop and administer the contracts. This usually is a one-time cost. The federal agency usually receives the power produced by the project at a predetermined price over the life of the contract - which provides a hedge against utility rate volatility. The project developer gets the long-term contract it needs to attract investors. Note that some contract costs could be funded by DOE's FEMP. By acting as a contracting agent, WAPA provides an important service to federal agencies that are unable to sign 20-year contracts.

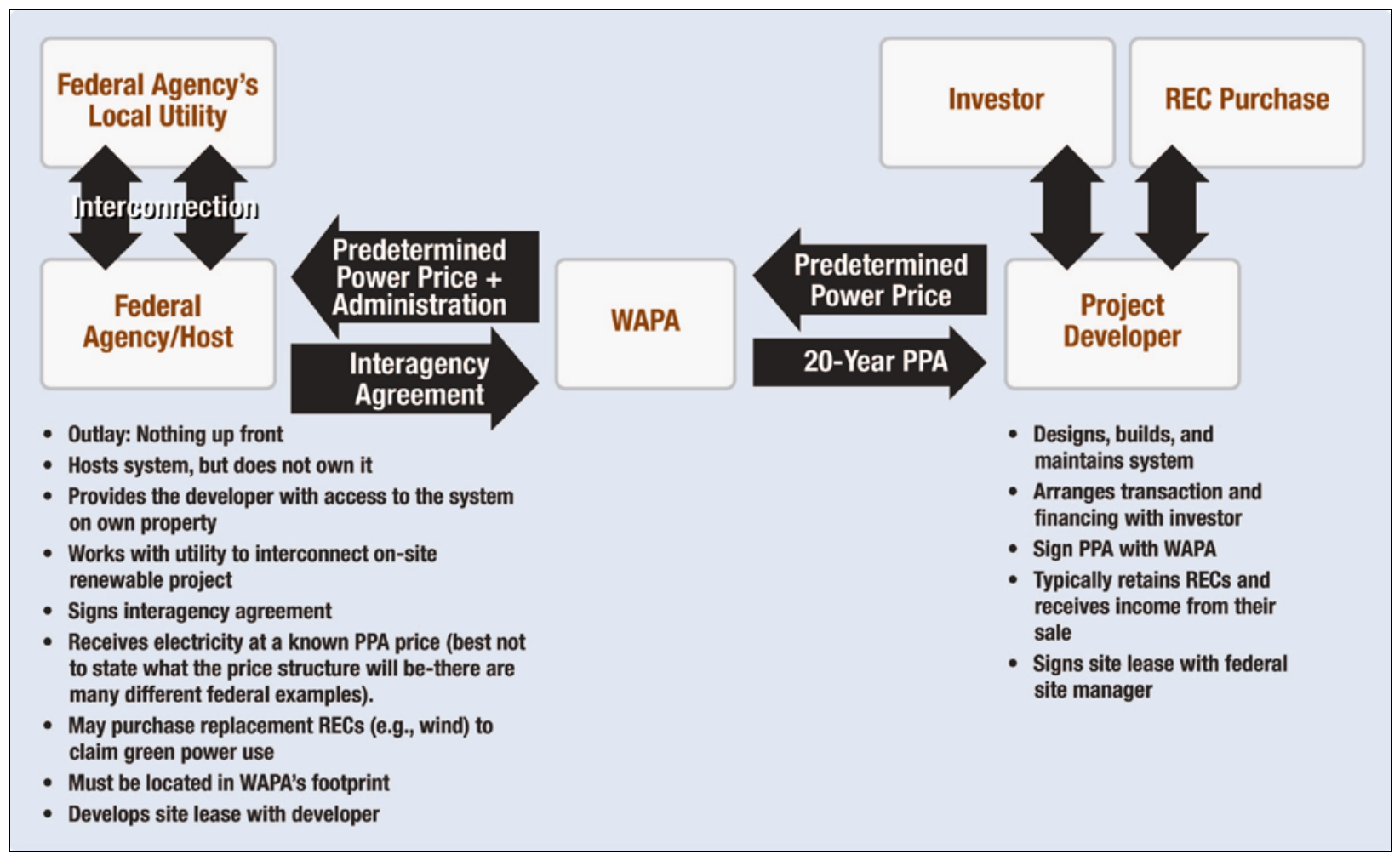

Figure 8. WAPA contracting agent model details 
One important question is whether the WAPA model can be replicated by other agencies outside of WAPA's service territory. Other power marketing administrations (PMAs) might be able to play this contracting agent role. One advantage that WAPA has is its well-established federal renewable power program (see http://www.wapa.gov/powerm/pmtags.htm), which has been in place for more than 5 years. This program has allowed WAPA to gain practical experience in dealing with federal renewable energy issues, and in understanding the market nuances and contracting requirements associated with renewable energy projects on federal installations. The Defense Energy Support Center (DESC) recently has set up a renewable team to help federal agencies with developing and issuing PPA requests for proposals. Unlike WAPA, however, DESC does not have long-term contracting authority that extends 20 or more years.

\subsubsection{WAPA Example: Fort Carson}

Three-Phases Energy Services (now 3 Degrees) developed a 2-MW PV project at Fort Carson in Colorado, which was completed in December 2007. [94] The ground-mounted, thin-film PV system covers nearly 12 acres on an old Fort Carson landfill and produces 3,200 MWh annually. To support project development, SunTechnics, Inc. designed and constructed the project. The PV panels carry a 25-year warranty. [95]

WAPA acted as contracting agent on Fort Carson's behalf to acquire the electricity produced from the solar array at a fixed cost of $\$ 0.055 / \mathrm{kWh}$ over the 20 -year PPA. As a firm electric service (FES) customer of WAPA, Fort Carson was able to use the "support energy" provision of the FES contract to purchase the electricity produced by the solar array. The SRECs are sold to Xcel Energy, under the Solar*Rewards program, to support their customer-sited solar requirement under Colorado's RPS.[96] As described above (see Table 5), NREL estimated the price for Colorado SRECs to be in the range of from $\$ 160 / \mathrm{MWh}$ to $\$ 265 / \mathrm{MWh}$. The challenge is that SREC prices in the state are determined through auctions via private contracts with the utility, so exact prices are unknown.

\subsubsection{WAPA Example: National Renewable Energy Laboratory}

NREL has developed the Mesa Top PV Project, which has a capacity of $720 \mathrm{~kW}$ and will generate some 1,200 MWh annually, or 7\% of NREL's current annual electricity use. The system began commercial operation on December 19, 2008. [97]

This project is being accomplished via four agreements, including: (1) a PPA between WAPA/DOE and SunEdison; (2) an inter-agency agreement between WAPA and DOE; (3) an easement/access agreement between DOE and SunEdison; and (4) a SREC/rebate agreement between SunEdison and Xcel Energy. For a visual of these relationships see Figure 9 below. WAPA is the contracting agent on behalf of DOE (Golden Field Office) and NREL, to provide SunEdison with a 20-year contract that parallels the 20-year SREC contract that Sun Edison signed with Xcel Energy. SunEdison will finance, build, own, operate, and maintain the system. [98] As part of making the project financially viable, SunEdison will receive the federal tax credits, the revenue from the sale of electricity to DOE/NREL (via WAPA), and revenue from Xcel Energy's rebate and purchase of RECs. [99] WAPA will use its power purchasing authority to buy electricity on behalf of DOE for a 20-year term. 


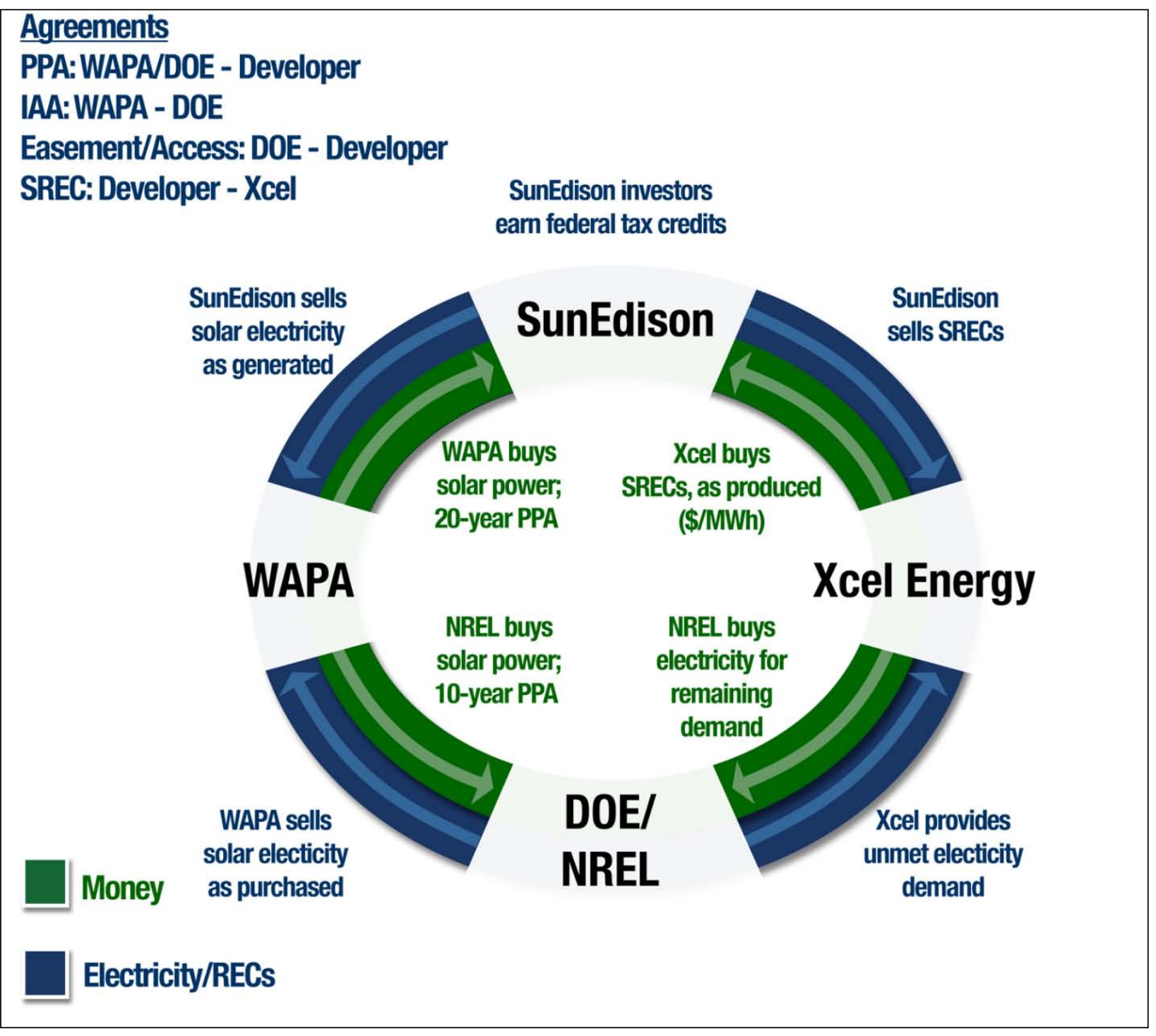

Figure 9. Dynamics of Mesa Top PV Project (Westby, B. "NREL Program Manager, Federal Energy Management Program \& Sustainable NREL: Congressional Staff Study Tour,” August 18-20, 2008)

The Mesa Top PV Project is considered the Phase I project for NREL in its efforts to meet and exceed the renewable energy goals and requirements of EO 13423 and EPAct 2005. Three additional Phase II PV projects were awarded May 2008, which replicate the Mesa Top PV Project agreement structure described above. [100] These include:

- A 1.16-MW (1,830-MWh) ground-mounted PV installation at the National Wind Technology Center;

- A 725-kW (1,000-MWh) ground-mounted PV system near the Research Support Facility at the South Table Mountain Campus; and

- A 118-kW (161-MWh) rooftop PV system at the Science \& Technology Facility.

As described in this section, the third-party ownership/PPA model is being used in the federal sector as a way to effectively monetize federal tax benefits, avoid paying the up-front cost of 
solar, more efficiently allocate public funds, and accelerate the deployment of PV. Federal agencies located in the west can partner with WAPA as a contractual intermediary to help them take advantage of this PV financing model. The next section describes federal agency use of performance contracts, which can also be used in conjunction with the third-party ownership/PPA financing model.

\subsection{Energy Savings Performance Contracts and Utility Energy Service Contracts Financing Models}

Enlisting the support of the private sector to finance energy efficiency and conservation upgrades at federal facilities has been taking place under performance contracting for decades. Use of these partnerships is accelerating as the federal government pursues aggressive energy intensity and renewable energy goals and mandates (described above). The Energy Independence and Security Act of 2007 in Section 514 permanently authorizes the use of ESPCs ${ }^{34}$ by federal agencies. [101] In addition, EISA 2007 encourages agencies to utilize the full 25-year contracting authority for the energy savings performance contracts, or ESPCs. [102]

From 1992 through 2007, more than 460 ESPCs have been implemented by 19 different federal agencies in 47 states. Approximately $\$ 2.3$ billion in private-sector funds has been invested in U.S. federal facilities through ESPCs, saving 18.5 trillion Btu annually-equivalent to the energy used by a city of about 518,000 . It is estimated that these projects will save the government $\$ 7.1$ billion in energy costs, with $\$ 5.7$ billion of that going to pay off project investment. [103] DOE actively has pursued use of ESPCs. On December 18, 2008, for example, 16 additional contracts were awarded by the DOE for up to $\$ 80$ billion in energy efficiency, renewable energy, and water conservation projects at federal facilities. [104]

Energy savings performance contracts create a vehicle for a federal agency to make necessary investments in energy efficiency upgrades, including on-site generation and water conservation - sometimes without having to commit to an up-front outlay of capital. In these instances, a private-sector entity provides the up-front funding for the cost of purchasing and installing new energy-efficiency equipment and recoups this investment over time (up to 25 years). The agency repays the performance contractor using cost savings from avoided energy consumption (details described below). These private-sector performance contractors can be either an energy services company (ESCO) or a utility under a utility energy service contract.

Including renewable energy in an ESPC or UESC still is a relatively novel phenomenon for a number of reasons. Renewable energy projects traditionally have a longer payback period than the majority of energy conservation measures (ECM). The greater cost and longer payback period could be amplified if the ESCO charges a $25 \%$ to $30 \%$ mark-up on PV as an ECM (even though the mark up is negotiable). Additionally, the traditional utility or the ESCO might not have the renewable energy technical expertise; although in the instances where PV has been incorporated into an ESPC, the performance contractor awarded a subcontract for the PV installation to a solar installer. Lastly, financial incentives are critical to the success of renewable energy and PV in particular, which limits where such projects are feasible to a handful of states.

\footnotetext{
${ }^{34}$ Note that the original authorization was in April 1986 and was called Shared Savings. EPAct 1992 changed the name to ESPC and added clarifying statutory text. Personal Communication with Doug Dahle, National Renewable Energy Laboratory, February 4, 2009.
} 
Combining PV with a series of energy conservation measures that have shorter investment payback horizons, however, enables the entire portfolio of projects to have a shorter payback period than the PV system would have on its own. Additionally, investing in ECMs to reduce energy consumption will enhance the benefits of a PV system. All else being equal, either the PV system will offset a greater percentage of the facility's energy demands or a smaller and lessexpansive PV system can be installed and reduce energy demand the by the same percentage.

The structure receiving considerable attention is the combining of an ESPC with a third-party ownership/PPA contract. In this case, a federal agency takes ownership of the ECMs but not the PV system. Instead, the agency hosts a PV project on-site and signs a long-term contract with a third-party for the electricity at a predetermined, stable price (as described previously). Examples of this structure are described below. Regardless of the details of the deal, it is clear that energy service contracting is playing an increasing role in deploying federal PV systems. ${ }^{35}$

\subsubsection{Energy Services Companies}

Energy service companies evolved from the needs of building owners to make major investments in energy performance in instances where there was a shortage of project capital, energy system expertise, or both. Energy service companies were typically engineering services consultants or building control manufacturers who chose to assume the risk of project financing in order to increase revenue. [105] Some ESCOs are able to finance energy conservation projects on their own balance sheets (e.g., Johnson Controls). Typically ESCOs bring in investors as financial partners, such as GE Capital, Hannon \& Armstrong, and United Financial.

The most common ESCO contracts are "guaranteed savings" projects. In this situation the building owner finances the up-front project costs and the ESCO guarantees the electricity and natural-gas savings related to that project, compared to a projected baseline (i.e., what would have happened without the project). If the project does not perform as anticipated, then the ESCO covers the cost of the additional energy consumption. If the project performs better than anticipated, then the additional savings are shared between the federal agency and the ESCO.

Most ESPCs are considered performance-based projects, and the ESCO is paid out of the energy savings and pursues projects that minimize the payback period. Many ESCOs, however, now offer "comprehensive" contracts which seek to achieve energy savings from the widest possible array of cost-effective measures at a given facility. Comprehensive contracts typically are more complex because they often go beyond the most obvious projects and include projects with longer payback periods, including PV systems.

A good example of a federal agency using an ESCO to pursue a PV project is Twentynine Palms, a U.S. Marine Corps compound in the Mojave Desert in California. In 2002, as part of an ESCO, Johnson Controls installed a 1.29-MW tracking solar photovoltaic system. In the first summer of operation the system produced about $5 \%$ of the base's electricity needs. [106] At the time, the PV system was one of the largest non-utility PV systems in the world. The \$51-million contract was one of the largest ESPCs ever awarded by the Naval Facilities Engineering Command Contracts office. The solar installation, in conjunction with energy efficiency measures

\footnotetext{
${ }^{35}$ This trend is discussed in more depth in Integrating PV into Performance Contracts: Barriers and Trends, by Wilson Rickerson, Center for Energy \& Environmental Policy, University of Delaware, 2004.
} 
undertaken as part of the ESPC should save the base about $\$ 6.9$ million each year over the course of the contract's 20-year term, for a total savings of \$138 million. [107]

\subsubsection{Utility Energy Service Contracts}

Recently, many UESCs have been established, usually as a compliment to a utility's existing demand-side management program. [108] Other than the fact that facilities are owned and operated by franchised or serving utilities, these financing structures work in a similar fashion as a with a typical ESCO. Most UESCs offer shared savings and performance-guarantee contracts, enabling federal agencies to pursue energy systems improvement without capital outlay. The Energy Policy Act of 1992 (42 U.S.C. $§ 8256$ ) provides permanent authority for UESCs and therefore authorizes and encourages federal agencies to work with UESCs whenever it is advantageous to do so. [109] Conveniently, UESCs are offered on a sole-source basis, without the need for a full-fledged competitive process.

Federal agencies can establish contracts with a UESC through an existing GSA area-wide contract, basic ordering agreement, or a separate installation contract. Alternatively, agencies also can establish entirely new "stand-alone" contracts. [110] ${ }^{36}$ Regardless, agencies considering any new contracts should refer to the model utility service agreement developed by the Edison Electric Institute, Department of Defense (DOE's FEMP), and other federal agencies. This model agreement [111] includes all the essential language that federal agencies should include in a UESC contract.

\subsubsection{Utility Energy Service Contract PV Example: Camp Pendleton}

At Camp Pendleton, between Fiscal Years 2002 and 2004 the U.S. Marine Corps utilized several UESCs (and an ESPC) to achieve a 44\% reduction in energy consumption despite, a 2 millionsquare-foot increase in facility space. In addition to substantial energy conservation measures (e.g., lighting, daylighting, efficient HVAC), Camp Pendleton's UESCs included the installation of more than 200 solar-powered street lights and caution lights. The success of these installations led to the use of a variety of solar-powered applications, including lighting at bus stops, carport electric vehicle charging stations, wastewater overflow detection stations, and the powering of notification and communication systems. [112] The base is expected to save about $\$ 1.3$ million annually and reduce energy consumption by more than 3.7 million $\mathrm{kWh}$ and 129,000 therms. [113]

\subsubsection{Utility Energy Service Contract PV Example: Chicago Social Security Center} The Harold Washington Social Security Center in Chicago hosts the largest federal solar installation, a 100-kW array on the 8,000-square-foot roof. [114] The installation came on line in the summer of 2005 and generates enough electricity each day to power 100 homes. In fact, the solar array has performed beyond expectations and is making more energy than initially was anticipated. [115] The Social Security Administration (SSA) estimates that the solar system will reduce carbon dioxide emissions by 1,900 tons over the next 30 years - the equivalent of

\footnotetext{
${ }^{36}$ Area-wide contracts (AWC) are blanket contracts - essentially indefinite-quantity, indefinite-delivery contractsfor public utility services. The AWC spells out general terms and conditions and authorizes any agency in the utility's service territory to place delivery orders for services offered under the contract. Basic ordering agreements are not contracts, but establish the general terms and conditions for future contracts, making those contracts easier to put in place quickly.
} 
planting 545 acres of trees or avoiding driving 4.8 million miles on the roadways of Chicago. [116]

The project was financed using a UESC and operational budget allocations; no city, state or utility incentives were used to support this project. The USEC was with the local utility company, Commonwealth Edison Company (ComEd) and Powerlight (now SunPower) supplied the panels. The project cost about $\$ 1$ million. This was paid for with a $\$ 350,000$ down payment before the installation, and 6 monthly payments included in the ComEd utility bill over 6 consecutive months for the remaining \$650,000.[117] The SSA covered the up-front payment using that year's entire "energy projects" budget; payment was allocated as certain milestones were met (e.g., design accepted, equipment ordered). Monthly costs were covered using operational budget allocations which were possible because other projects for that year were scaled back. ComEd handled the management duties for the installation. [118]

\subsubsection{Super ESPC Contracts}

To streamline the process of obtaining ESPCs, the DOE has evaluated and prequalified a select number of ESCOs to provide site-specific ESPC contracts. Federal agencies interested in using Super ESPCs (also known as IDIQs, indefinite delivery indefinite quantity) are able to work with the ESCOs without executing a full competitive bidding process themselves. By establishing the general parameters of any contract agreement and prequalifying capable ESCOs, DOE has made the ESPC process easier. In Super ESPCs, the vendor guarantees specific levels of water conservation, energy efficiency, and renewable energy in the contract. Additionally, Super ESPCs have helped to make financing cheaper. In the last few years, the premium for financing was reduced from 150 to 200 basis points over the London Interbank Offered Rate (LIBOR), ${ }^{37}$ down to 75 to 125 basis points (the higher end of the scale usually includes renewable projects). [119]

The concept of working with ESCOs first was instituted in 1986. In 1992, Congress passed legislation enhancing the partnership structure and which also changed the name to ESPC. Implementation did not occur until 1995, however, with the promulgation of DOE program regulations. [120] Since then, 19 different federal agencies that have taken advantage of the streamlined Super ESPC contract process including: DOE, DOD, National Parks Service, National Aeronautics and Space Administration, Department of Transportation, and Bureau of Indian Affairs. [121] A directory of ESCOs approved by the Department of Energy can be found at http://www1.eere.energy.gov/femp/financing/superespcs_espcescos.html.

There are two basic kinds of Super ESPCs. The first is a "general-purpose" ESPC and it allows agencies to engage ESCOs for typical energy-efficiency and conservation measures. The second type of Super ESPC is termed "technology specific," and is designed to procure help for agencies in implementing advanced technologies such as solar, biomass, and geothermal heat pumps. A technology-specific ESPC must focus on advanced energy technologies, but bundling a project like this with more conventional savings measures is both effective and encouraged.

\footnotetext{
${ }^{37}$ LIBOR is the London wholesale market rate at which banks lend money to each other. Basis points represent $1 / 100$ th of a percentage point, therefore 150 basis points is $1.5 \%$ more than LIBOR.
} 


\subsubsection{Super ESPC PV Example: Coronado Naval Base}

In September 2002, Coronado Naval Base in San Diego, California, was one of the first federal entities to utilize a technology-specific Super ESPC to enable installing of a $750-\mathrm{kW}_{\mathrm{AC}}$ PV system in its parking lot. At the time it was completed this was the largest PV system in use by the federal government - consisting of 3,078 photovoltaic panels. [122] The panels cover 81,470 square feet on top of several carports and the roof also serves to shade the roughly 400 vehicles that park beneath the structure daily. The electricity generated by the system meets $3 \%$ of the naval base's summer electricity load (peak demand), and is equivalent to powering about 935 homes.

The total cost for the solar installation was approximately $\$ 7.7$ million. This total was reduced with a \$3.6 million buy-down from the San Diego Regional Energy Office (SDREO) as well as $\$ 1.8$ million in supplemental money from the DOD. [123] The net $\$ 2.3$ million was partially funded through a combination of Navy Public Works Center (federal) buy-down and ESPC financing.[124] The prime contractor for this project was Noresco/ERI Services. The subcontractor and manufacturer of the system was Powerlight Corporation (now SunPower). The annual operating costs savings started in year one, at $\$ 228,000$. [125] Having been bundled with other energy conservation measures, the $\$ 15.5$ million project had a payback of 5.8 years. [126] The Navy currently is looking to expand the use of solar power at this site based on the success of this project.

\subsubsection{Super ESPC PV Example: Sherman Indian High School}

In a smaller-scale project, Sherman Indian High School utilized a Super ESPC to work with SEMPRA Energy Solutions. The project resulted in a $40 \%$ reduction in energy consumption at the school. The DOE already had purchased a 7-kW solar power system for the school. SEMPRA included installation of the system and training on its operation and maintenance as part of the ESPC. [127]

\subsubsection{ESPC in Conjunction with Energy Services Agreement}

As described in Section 5.2, some federal agencies are taking advantage of the third-party ownership/PPA model to help finance PV projects. Interestingly, this model is being incorporated as a component of ESPCs through an energy services agreement (ESA). The goal of the ESA not only is to deploy on-site generation (like solar PV), but also to reduce total on-site energy usage. ${ }^{38}$ The energy services companies asked to include solar energy in their ESPCs typically turn to a specialized solar-energy company to provide third-party financing and ownership of the system. The advantage of this approach is that it typically allows the ESCO to incorporate solar without assuming the risk of financing that element of the project.

The ESA, like a PPA, is signed between an ESCO and an agency. The relationship between the ESCO and the PV developer basically is a subcontract, although if the PV developer wants to be the owner and bring equity and financing to the project, then the ESCO is expected to sign an "operating lease" with the PV developer/owner.

The ESA can include the following terms:

\footnotetext{
${ }^{38}$ The model probably will not be part of UESC models because utilities currently are not allowed to take advantage of the ITC as credit against their own tax payments - a critical component to financing solar PV economically.
} 
- PV energy rate (typically $₫ / \mathrm{kWh}$ )

- Rate escalation (if applicable)

- Duration and quantity of annual PV energy delivery

- Responsibility for PV system operations and maintenance (should be ESCO or PV developer)

- Alternatives for title and disposition of PV system at end of ESPC contract term.

Several companies finance, install, and operate solar energy projects at a site where long-term (typically 20 year) power purchase agreements are signed. Companies such as SunEdison, MMA Renewable Ventures, SunPower, Chevron Energy Services, and others currently are providing these services, primarily to private-sector clients. These contracts are custom tailored to the sites and clients and they can include both options to extend the term of the ESA as well as options to purchase the system.

The only ESCO currently handling the solar element of the ESPCs internally is Honeywell. By keeping the solar projects on its own balance sheet, Honeywell is able to obtain solar tax credits against its federal tax liability. The resulting tax savings are incorporated into the electricity price in the ESA.

\subsection{Additional Information on ESPCs and Super ESPCs}

Many resources are available to help federal agencies understand the options for deploying PV as part of an ESPC or a Super ESPC. The first resource any federal agency should use is DOE's FEMP Web site at http://www1.eere.energy.gov/femp/financing/mechanisms.html. The Web site contains a wealth of information for federal agencies and energy managers.

Another helpful step is to enroll in a FEMP training course on ESPCs and Super ESPCs. These provide all the information a federal manager needs to implement these types of contracts. More information on this type of training (including a schedule) can be found at:

http://wwwl.eere.energy.gov/femp/financing/superespcs_training.html.

Screening the potential sites to identify which have the best combination of renewable resource and incentives to implement PV also is important. Appendix E provides an explanation of the critical steps needed to screen a federal agency's sites, and gives some specific examples of how such screenings were used by the DOD and the Department of Labor.

Federal agencies that are ready to move forward with procurement can secure additional technical help at no cost from DOE FEMP through the Initial Proposal stage - without the need for an Interagency Agreement. This technical assistance can help federal agencies design and develop an appropriate procurement plan. After the Initial Proposal, FEMP services can be provided on a cost-reimbursable basis through an Interagency Agreement which spells out tasks and costs of FEMP project facilitation. For more information on FEMP support on ESPCs, review the program overview at http://www1.eere.energy.gov/femp/pdfs/espc_toolkit.pdf.

\subsection{Multi-Year Construction for Federal System Ownership}

For federal agencies interested in directly owning PV projects, but which are unable to secure enough funds for a very large project in a single year, there is a unique option for building over several years. The cash buyout structure also is relevant for projects in states that do not have the 
economic incentives needed for the third-party ownership/PPA model (e.g., Oregon, Hawaii, North Carolina). In working with the PV installer, it is possible to stretch the installation - and thus the payment period - over 5 years. During this period, an agency includes annual payment in its budget, or can commit most/all of its energy conservation/management funds to a large PV project. This enables the agency to spread the payments of a large system over time. This does require assuring the developer that funds will be received over the entire 5-year period.

The challenge is that projects at minimum must be $20 \mathrm{MW}$ to make this economically feasible. The critical component is to keep the labor on-site and working over the 5-year period-for a number of reasons. First, the cost of mobilizing an installation crew is significant and it does not make economic sense to remobilize a crew several times on the same project. Also, by using the same delivery/installation team, the consistency and the quality of installation is improved; this is important, as it is unlikely that an installer can commit to keeping the same crew working over a 5-year period on a small project.[128] Although this mechanism is not likely feasible for many federal agencies, it could be feasible in the right circumstances.

\subsection{Summary of Federal PV Financing Models}

As explored in this section, there is a wide variety of financing options available to federal agencies interested in deploying and financing PV on their property. Many of the financial structures can be complex but, importantly, the federal agencies can partner with the private sector to help.

Complimentary energy-efficiency activities are important for deploying federal-sector PV, because the portfolio of projects will have a significantly reduced payback period than a PV project alone. Federal agencies can use performance contracting (ESPC, UESC) in combination with an ESA (commonly called a third-party owned PPA) to achieve this combined portfolio without the up-front costs or operations and maintenance responsibilities, and with guaranteed savings over time. The ESPC contracts allow for 25-year terms; this provides a mechanism to deploy PV for federal agencies that have limited energy-procurement authority (10 years), if the PV developer requires 20-year contracts.

The DOE has made ESPCs and UESCs more accessible to federal energy managers in two ways. First, by pre-approving select ESCOs, the DOE has streamlined the procurement process; the federal agency does not have to execute a full competitive bidding process itself. Second, the general parameters of any contract agreement are predetermined, which can help facilitate the actual development of the performance contract by starting from a common set of basic parameters.

Although performance contracting is the most widely available financing mechanism for federal agencies, the third-party owned PPA structure also is gaining popularity. Without the advantage of ECMs as part of the project portfolio, these projects often require a large size (to secure the economies of scale to bring down project costs) and also significant payments either through state-level incentives or SRECs. Therefore, using the third-party owned PPA model outside of an ESPC or UESC currently generally is more feasible in the states with the best PV incentives or with a specific solar set-aside in their RPS. 
An additional challenge with using the third-party owned/PPA structure alone is that many federal agencies are unable to sign procurement contracts for terms longer than 10 years. Fortunately, federal agencies located in WAPA's service territory can work with WAPA as a contractual intermediary, because its contracting authority extends the necessary 20 years. Even federal agencies that are not currently WAPA preferred customers can work with WAPA to develop PV using the third-party owned/PPA model. Even though WAPA will be an advisor in the development process and will facilitate contracting, it is up to the hosting federal agency to lead overall project development (including selecting the renewable energy developer).

In summary, federal agencies have several options for financing PV projects on their property. Incorporating energy efficiency can be crucial for including PV in the project portfolio and is accomplished most easily using an ESA in combination with an ESPC, UESC, or even a Super ESPC. Directly using the third-party ownership/PPA model without executing a performance contract is possible; federal agencies can either take advantage of WAPA's procurement authority, or can use their own if it extends 20 years. 


\section{Federal Agency PV Revenue and Incentive Analysis}

To evaluate the potential options available to federal agencies for financing and deploying PV systems, NREL conducted an analysis using the Solar Advisor Model (SAM) [129], which was developed at NREL. This section explains the SAM model, assumptions, analysis methodology and results of that analysis. The results compare resultant levelized cost of electricity generation $^{39}$ (LCOEG) under different incentives and financing structures available to federal agencies, and highlight the differences between regions.

\subsection{Solar Advisor Model Background}

The Solar Advisor Model Background (SAM) was developed by staff at NREL and Sandia National Laboratory to provide a comprehensive analysis modeling tool of solar technology systems to support the federal research and development (R\&D) community and the solar industry. This tool enables investigation of the impact of variations in physical, cost, and financial parameters to better understand their impact on key metrics related to system price and performance. These metrics include system output, system efficiencies, levelized cost of electricity generation, return on investment, system capital cost requirements, and operations and maintenance costs.

The SAM system can analyze various impacts on LCOEG of PV project financing. It can examine the impacts of financial variables like loan-debt fraction and term of loan. Additionally, the "commercial loan" module can model self-financed projects, even for federal agencies, and the third-party ownership/PPA module calculates results from third-party-owned financing structures. The calculated financial metrics include annual cash flow throughout the project life, the LCOEG for the system, tax payments, the net present value of the system, and the internal rate of return. For utility-scale systems using the perspective of the independent power producers (IPPs), the model calculates the necessary PPA value and future escalation rate that is needed to make the project viable.

Additionally, SAM has the ability to add financial incentives to the system; all standard federal, utility, and state-level incentives can be included. The tax implications and final impact on the SAM outputs then is included both in the annual cash flow and the resultant levelized cost of electricity generation. Likewise, the user can input values for a production tax credit, an up-front rebate (total dollars), a capacity-based incentive (a buy-down in $\$ / \mathrm{W}$ ), or a production-based incentive (either a state or utility cash incentive or an SREC, in $\phi / \mathrm{kWh}$ ). The tax implications of each of these incentives vary with location and will be subject to any future tax changes implemented. It is possible to adjust the default values for the tax impact of these incentives by changing the taxable status of the incentive, if the incentive reduces the ITC basis or if the incentive reduces the depreciation basis. Federal, state, and utility incentives often are critical financial components to PV systems, therefore incentives are an important component of SAM and open its use to various solar policy analyses.

\footnotetext{
${ }^{39}$ The levelized cost of electricity generation includes the all-in cost of the equipment (which includes installation and interconnection), as well as the cost of financing (both debt interest rate and equity returns), and other ancillary costs (if applicable) such as insurance, land payments, and taxes. Levelized cost of electricity generation also factors in all available incentives.
} 


\subsection{PV Financing Analysis-Methodology and Assumptions}

California, Colorado, and New Jersey were selected to site theoretical PV systems in the analysis, because they have strong and varied incentives and high solar energy market prices. The final result is a side-by-side comparison of LCOEG under third-party ownership/PPA and cash/commercial loan models. Assumptions about performance, cost, finance, and incentives are described below. Note that, under the third-party ownership/PPA structure, the entity that owns the system must pay taxes on it, but when a federal agency owns the system it is exempt from paying any taxes, including sales tax. This is taken into account in the modeling.

\subsubsection{System Size and Performance}

Two system sizes and types were selected as potential applications for federal projects. Both a roof-mounted $100-\mathrm{kW}$ system and a $500-\mathrm{kW}$ ground-mounted system were analyzed. For the rooftop PV system, the tilt angle was set to 20 degrees (based on maximum mounting angles available from common mounting-rack manufacturers). The $500-\mathrm{kW}$ system was assumed to be a fixed-tilt system with the tilt angle set at the latitude of the city in which it is assumed to be sited. This configuration typically maximizes solar panel output.

Inverters were sized based on the nameplate rating of the PV system (100 kW or $500 \mathrm{~kW})$. Inverters come with a 10-year manufacturer's warranty, which was assumed to be the inverter lifespan. To account for inverter replacement, the replacement cost was amortized and added to operations and maintenance costs. The PV panels themselves are assumed to last the full span of the analysis period because they come with a 20 - to 25 -year warranty. Finally, system degradation was assumed to be $0.5 \%$ per year which is an average degradation coefficient for both single-crystal silicon and multi-crystal silicon PV panels. [130]

\subsubsection{System Capital Costs}

Capital costs were based on cost information from Solar Buzz and product catalogues, as compiled by NREL. NREL also estimated installed costs of PV systems in California and New Jersey. The samples collected were installed between January 1, 2007 and November 14, 2007. The cost information of roughly 850 medium- to large-sized systems was averaged for the California estimate of installed cost. ${ }^{40} \mathrm{NJ}$ Clean Energy's compilation of cost information of 162 medium and large systems provided the New Jersey estimate. Installed cost numbers were not readily available for the state of Colorado, therefore costs were estimated by averaging the cost statistics from California and New Jersey. Annual operations and maintenance costs per kilowatt were configured based on a Sandia National Laboratory estimate [131]. Table 6 shows the total installed cost of PV that was assumed, by location and size of project.

\footnotetext{
${ }^{40}$ Program information from the California Energy Commission's Emerging Renewables Program and the California Solar Initiative.
} 
Table 6. Total Installed Costs per Capacity (\$/Wdc)

\begin{tabular}{|l|c|c|}
\hline State & $\mathbf{1 0 0} \mathbf{~ k W ~ ( \$ / W d c ) ~}$ & $\mathbf{5 0 0} \mathbf{~ k W ~ ( \$ / W d c )}$ \\
\hline $\begin{array}{l}\text { California (third-party owned, } \\
\text { including sales tax) }\end{array}$ & $\$ 7.93$ & $\$ 6.87$ \\
\hline $\begin{array}{l}\text { California (federally owned, no } \\
\text { sales tax) }\end{array}$ & $\$ 7.60$ & $\$ 6.67$ \\
\hline Colorado & $\$ 8.04$ & $\$ 7.01$ \\
\hline New Jersey & $\$ 8.65$ & $\$ 6.94$ \\
\hline
\end{tabular}

Source: Dean, J. "2007 Total Installed Costs Module." National Renewable Energy Laboratory Internal Spreadsheet. 2008

\subsubsection{Financing Assumptions}

Tax assumptions must be made carefully when using SAM. Federally owned projects do not pay taxes, so no tax payments are assumed when a federal agency owns the system. The total installed costs gathered for Table 6, however, are assumed to include sales tax for California. Therefore, for federally owned systems in California, sales tax payments were estimated and then subtracted to get the true installed cost for federal systems. Colorado and New Jersey exempt renewable electric equipment from sales tax, so no adjustment was necessary.

For the third-party ownership/PPA model, the private investor that owns the system must pay relevant taxes and must be included in the modeling. All third-party owned projects are assumed to pay the federal and state taxes for the particular location, which combined equal the total tax rate shown in Table 7. Sales tax rates are included in Table 7 to indicate the value of the state tax exemptions in Colorado and New Jersey. For the sake of simplicity, property tax rates were not included in this analysis, although they are discussed briefly. Property taxes vary between jurisdiction, and federal agencies are exempt from paying property taxes. Third-party developers, however, would be required to pay property taxes on the renewable equipment. California exempts PV system owners from paying property taxes, but neither Colorado nor New Jersey does; these rates were excluded from this analysis. 
Table 7. Federal and State Tax Assumptions ${ }^{41}$

\begin{tabular}{|c|c|c|c|c|}
\hline \multirow[b]{2}{*}{ Tax } & \multicolumn{3}{|c|}{ Third-Party Owned PV Systems } & \multirow{2}{*}{$\begin{array}{c}\text { Federally Owned } \\
\text { Projects }\end{array}$} \\
\hline & California & Colorado & New Jersey & \\
\hline Federal & $34 \%$ & $34 \%$ & $34 \%$ & $0 \%$ \\
\hline State & $8.84 \%$ & $4.63 \%$ & $9.00 \%$ & $0 \%$ \\
\hline Total tax rate & $42.84 \%$ & $38.63 \%$ & $43 \%$ & $0 \%$ \\
\hline Sales tax & $7.25 \%$ ** & $2.9 \% *$ & $7 \% *$ & $0 \%$ ** \\
\hline
\end{tabular}

Sources: A/N Group, Inc. and the Federation of Tax Administrators

For federal agencies, the inflation rate and discount rate are provided in the $10 \mathrm{CFR} \S 436 \mathrm{~A}$, FEMP-Methodology and Procedures for Life Cycle Cost Analyses. The nominal discount rate for 2008 is estimated at $4.9 \%$ and the calculated long-term inflation rate is $2.6 \%$. These rates are recommended for use for analysis of contracts up to 25 years in length. By default, SAM assumes that the PV system will be sized to be significantly less than the total demand of the host, and therefore no net excess electricity generation is sold back to the utility through net metering. The electric utility rate is used to calculate the net present value of the project.

The insurance rate for third-party owned systems was assumed to be $0.4 \%$, the default value in SAM and what was assumed for the DOE Solar America Initiative. No insurance was included when federal agencies self-financed the system, as the federal government self-insures all of its assets under one umbrella.

Under the third-party ownership/PPA model, the assumed internal rate of return for a project was an additional input (i.e., was set to zero for federally owned PV). Based on limited market intelligence gathered by NREL, the internal rate of return (IRR) was set at $8 \%$ for the third-party ownership model, which seems to be close to the minimum return deemed acceptable by the investors. NREL assumed that no debt was used to finance PV in the third-party ownership/PPA arrangement. [132] ${ }^{42}$ Additionally, the PPA was assumed to be at a fixed rate and the escalation rate was set to $0 \%$.

Under the commercial self-financed structure, the effect of using debt in project financing was investigated. Two cases were evaluated, one without debt (i.e., full, up-front cash payment) and one with a $60 \%$ loan fraction.

\footnotetext{
${ }^{41}$ Federal Tax rate from A/N Group, "Corporate Income Tax Rates - 2009, 2008, 2007, 2006, 2005, 2004, 2003" http://www.smbiz.com/sbrl001.html\#ci. Accessed June 8, 2009. Federal Corporate Income Tax Rates range from $34 \%$ to $38 \%$ depending on quantity of taxable income, State tax rates from the Federation of Tax Administrators table: "RANGE OF STATE CORPORATE INCOME TAX RATES (For tax year 2008 -- as of January 1, 2008)" http://www.taxadmin.org/fta/rate/corp inc.html. Accessed June 8, 2009. Special note for New Jersey only: Corporation business franchise tax rate. Corporations with net income of less than $\$ 100,000$ are taxed at $7.5 \%$. Corporations with net income of less than $\$ 50,000$ are taxed at $6.5 \%$. A 4\% surtax applies through July 1, 2009. The minimum tax is $\$ 500$. An Alternative Minimum Assessment based on gross receipts applies if greater than corporate franchise tax. Banking and financial corporations are subject to the franchise tax.

${ }^{42}$ According to Jimmy Chuang of MMA Renewable Ventures, MMA is the only corporation to structure debt for its third-party ownership PV financing deals.
} 


\subsubsection{Federal Tax Incentives}

In this analysis, the federal investment tax credit and 5-year MACRS depreciation schedule are assumed to be available for commercial third-party developers building projects at federal agencies.

Third-party developers also are able to take advantage of a 5-year MACRS depreciation schedule under which investment costs are recovered through accelerated income tax deductions for depreciation. ${ }^{43}$ The U.S. tax code specifies that, when a commercial entity takes the ITC, the "depreciation basis" of the project must be reduced by half the value of the ITC. Thus a thirdparty developer taking the ITC will be able to depreciate $85 \%$ of the project's costs for tax purposes using MACRS.

\subsubsection{State-Specific Cash Incentives}

Incentives vary by state and also can vary by utility service territory. In California, three utility districts are eligible for the California Solar Initiative (CSI) rebate schedule: PG\&E, SCE, and SDG\&E. The theoretical systems modeled in this analysis were sited in San Diego. Note that San Diego Gas \& Electric has higher incentive levels because fewer people have taken advantage of the rebates as of yet. Specific incentive levels for different sized systems and locations can be found on the CSI Statewide Trigger Point Tracker (http://www.csi-trigger.com/). As of July 2008, commercial developers receive an Expected Performance-Based Buy-Down (EPBB) of $\$ 1.9 /$ watt for systems $50 \mathrm{~kW}$ or smaller and government agencies receive an EPBB of $\$ 2.65 /$ watt. The EPBB is available in 2007 to projects less than $100 \mathrm{~kW}$, to projects less than $50 \mathrm{~kW}$ beginning in 2008, and to projects less than $30 \mathrm{~kW}$ beginning in 2010. [133] Large systems receive performance-based incentives instead of up-front rebates. At the current tier, commercial developers receive $\$ 0.26 / \mathrm{kWh}$ for 5 years, which was assumed for third-party owned systems (both $100 \mathrm{~kW}$ and $500 \mathrm{~kW}$ ). Federal government developers receive $\$ 0.37 / \mathrm{kWh}$ for 5 years, which is assumed when federal agencies self-finance PV systems.

In Colorado, up-front rebates are available to commercial developers and federal agencies from the investor-owned utilities, Xcel and Aquila. Under the Xcel Solar*Rewards programs, systems between $10.001 \mathrm{~kW}$ and $100.0 \mathrm{~kW}$ are eligible for $\$ 2 / \mathrm{W}$-DC rebate. For installing systems greater than $100.001 \mathrm{~kW}$, developers receive a $\$ 200,000$ up-front cash incentive. REC contracts for the energy generated also are provided (see Section 6.2.6).

Through the end of 2007, sizable rebates were available for customers under the New Jersey Customer On-Site Renewable Energy (CORE) Program. This historic rebate program will be considered and compared to the market-based programs available after that. As noted, New Jersey has moved away from up-front rebates (given in conjunction with SREC payments) toward an SREC-only structure. The CORE rebate level depended on sector and size of the project. Effective September 1, 2007, private-sector and PPA customers were offered $\$ 2.25 / \mathrm{W}$ for $100-\mathrm{kW}$ systems, and $\$ 2.00 / \mathrm{W}$ for $500-\mathrm{kW}$ systems. Public and non-profit sector developers were offered $\$ 2.50 / \mathrm{W}$ for $100-\mathrm{kW}$ systems, and $\$ 2.30 / \mathrm{W}$ for $500-\mathrm{kW}$ systems.

\footnotetext{
${ }^{43}$ If MACRS were not available, then taxable entities otherwise might use a 20 -year straight-line depreciation schedule for equipment costs. Thus, the 20 -year straight-line depreciation schedule is used as a baseline for comparison in this analysis. This is because the value to the project of MACRS only can be understood within the context of the partnership between the federal agency and developer.
} 


\subsubsection{State-Specific Solar Renewable Energy Credit Prices}

Solar RECs (SRECs) can be used as a market-instrument to assist in financing solar projects. The SREC contracts can be provided in conjunction with other state or utility-level incentives or they can be the sole mechanism of financing a system (as is the case in a New Jersey pilot program). No SREC contracts are offered for financing customer-sited PV in California because there is no solar set-aside within the RPS legislation and because REC trading values are low in the state.

In Colorado, investor-owned utilities must meet the $4 \%$ solar set-aside in the RPS with SRECs, half of which must come from customer-sited projects. To meet this quota, Xcel Energy provides 20 -year contracts for SRECs to customers under the Solar*Rewards program (in conjunction with the incentives described above). PV projects of between $10 \mathrm{~kW}$ and $100 \mathrm{~kW}$ are eligible for a contract for SRECs at a fixed price of $\$ 115 / \mathrm{MWh}$. Developers of large systems - between $100 \mathrm{~kW}$ and 2.0 MW - bid in a competitive RFP process for a REC contract with Xcel. In 2007, the range of SREC prices received was $\$ 206 / \mathrm{MWh}$ to $\$ 265 / \mathrm{MWh} .{ }^{44}$ This analysis assumes the median payment, $\$ 235 / \mathrm{MWh}$.

New Jersey also has a market for SRECs. Trading price data is available on the New Jersey SREC Web site.[134] The SREC payments in three different programs are considered: (1) the now closed ${ }^{45}$ CORE rebate program with historic SREC prices, (2) a Public Service Electric \& Gas (PSE\&G) Solar Loan program, and (3) an SREC-cap program, in which SREC prices are assumed to be at the price cap (an upper boundary). The 2007 CORE rebate program allowed customers to sell SRECs into the market. In 2007, the average of the weighted monthly averages for SREC prices was \$220/MWh.

The utility PSE\&G allows customers in its service territory to apply for a PV-system loan with PSE\&G and to repay it with SRECs. The interest rate is set at $11.11 \%$. The system owner receives the market price for SRECs, which the owner turns over to PSE\&G. PSE\&G has set a floor of $\$ 475 / \mathrm{MWh}$ for SRECs. This program is approximated in this analysis by assuming the floor price for the loan term of 15 years. If SREC prices are greater, however, then the loan will be repaid faster.

Finally, in an effort to test closing the CORE program, in 2008 NJ Clean Energy tested an SREC-only pilot program for financing solar. SREC prices are based on supply and demand, therefore all risk is borne by the program participant. To approximate the upper bound of this program, the solar alternative compliance payment (SACP) cap price was used for a period of 8 years (the total lifetime currently defined). If there is an undersupply of SRECs, then it would be likely that the prices will near the cap. In July 2008, a new schedule for the SACP was established, beginning in 2008 at a price of $\$ 711 / \mathrm{MWh}$. As the price trends down, an average of the yearly SACP prices is $\$ 654 / \mathrm{MWh}$, which was used as the SREC value in the SAM model over 8 years. It is important to note that, at the end of 2008, NJ SREC prices sometimes have exceeded \$600/MWh. [135] Therefore the SREC-cap case will be closest to this year's SREC prices.

\footnotetext{
${ }^{44}$ NREL calculation based on Xcel's 2008 Renewable Energy Standard Compliance Plan at http://www.xcelenergy.com/Company/Newsroom/News\%20Releases/Pages/Xcel_Energy_files_2008_Renewable_ Energy_Compliance_Plan.aspx.

${ }^{45}$ The program remains open for residential customers, but is closed for commercial and industrial customers.
} 


\subsubsection{Summary of Available Incentives and Assumed SREC Market Prices}

Table 8 below summarizes the different incentive programs highlighted in this analysis. If incentives vary between the public and private sectors, the difference in payments received also is emphasized.

Table 8. State-Specific PV Cash Incentive and SREC Price Assumptions

\begin{tabular}{|c|c|c|}
\hline State & Available to a 100-kW PV System & Available to a 500-kW PV System \\
\hline CA & $\begin{array}{l}\text { Performance-based incentives: } \\
\text { - Third-Party/PPA: } \$ 0.26 / \mathrm{kWh} \text { for } 5 \text { years, } \\
\text { - Self-financed by federal agency: } \\
\$ 0.37 / \mathrm{kWh} \text { for } 5 \text { years }\end{array}$ & $\begin{array}{l}\text { Performance-based incentives: } \\
\text { - Third-Party/PPA: } \$ 0.26 / \mathrm{kWh} \text { for } 5 \\
\text { years, } \\
\text { - Self-financed by federal agency: } \\
\$ 0.37 / \mathrm{kWh} \text { for } 5 \text { years }\end{array}$ \\
\hline $\mathrm{CO}$ & $\begin{array}{l}\text { Xcel } \$ 2.00 / \mathrm{W} \text { up front, and an SREC contract } \\
\text { for } \$ 115 / \mathrm{MWh} \text { for } 20 \text { years }\end{array}$ & $\begin{array}{l}\text { Xcel } \$ 200,000 \text { up front, and an SREC } \\
\text { contract for an average of } \$ 235 / \mathrm{MWh} \text { for } \\
20 \text { years }\end{array}$ \\
\hline \multirow[t]{3}{*}{ NJ } & $\begin{array}{l}\text { CORE Rebates: } \\
\text { - Third-Party/PPA: } \$ 2.25 / \mathrm{W} \text { and SRECs } \\
\text { averaging } \$ 220 / \mathrm{MWh} \text { for } 10 \text { years, or } \\
\text { - Self-financed by federal agency: } \$ 2.50 / \mathrm{W} \\
\text { and SRECs averaging } \$ 220 / \mathrm{MWh} \text { for } \\
10 \text { years }\end{array}$ & $\begin{array}{l}\text { CORE Rebates: } \\
\text { - Third-Party/PPA: } \$ 2.00 / \mathrm{W} \text { and SRECs } \\
\text { averaging } \$ 220 / \mathrm{MWh} \text { for } 10 \text { years, or } \\
\text { - Self-financed by federal agency: } \\
\$ 2.30 / \mathrm{W} \text { and SRECs averaging } \\
\$ 220 / \mathrm{MWh} \text { for } 10 \text { years } \\
\end{array}$ \\
\hline & PSE\&G Solar Loan: \$475/MWh for 15 years & PSE\&G Solar Loan: $\$ 475 / \mathrm{MWh}$ for 15 years \\
\hline & SREC-Cap: \$654/MWh for 8 years & SREC-cap: \$654/MWh for 8 years \\
\hline
\end{tabular}

\subsection{Federal PV Analysis Results}

The PV systems modeled in this analysis are meant to provide a general comparison of the different incentive structures in different state environments. Costs and investment incentives vary drastically, therefore it is important for organizations considering specific PV projects to perform their own analysis to capture their project's actual costs, currently available incentives, financing options, and actual resource quality. This analysis also does not consider the savings reflected in a customer's electricity bill as a result of having on-site generation-because this benefit is shared across all financing structures, it was considered out of scope. Entities interested in determining the LCOEG of a particular project, however, should include this important benefit.

As described below, the total benefit from including all available incentives and revenues is striking. For both the $100-\mathrm{kW}$ and the $500-\mathrm{kW}$ systems in all three locations, entering a power purchase agreement with a third party results in a reduced final LCOE, after incentives and REC payments are incorporated. The margin of benefit of the third-party ownership/PPA model depends on several site-specific variables.

\subsubsection{LCOEG of a 500-kW System}

The first set of results analyzes a 500-kW PV ground-mounted system, tilted at the latitude of the 3 system locations under study (San Diego, Denver, Atlantic City). The geographic differences of installed cost, capacity factor, available incentives, and REC revenues lead to different LCOEG in the 3 locations. The PSE\&G Solar Loan program, which is based solely on REC market prices, results in the lowest LCOEG overall. Although the incentive is not as much as the 
NJ SREC-cap price, its availability for 15 years as opposed to 8 years has the greatest impact on lowering the LCOEG. Xcel's Solar*Rewards program, which includes a cash incentive and REC payments, results in much lower LCOEG than does the cash payment method used in California. Again, Xcel's 20-year payments are for a longer period - as compared to 5 years in Californiawhich reduces the LCOEG. A comparison of LCOEG under the different incentive programs and financing structures is shown in Table 9.

Table 9. An LCOEG Comparison of Financing Structures and Average Retail Rate

\begin{tabular}{|c|c|c|c|c|c|c|c|}
\hline \multirow[b]{2}{*}{$\begin{array}{l}500 \mathrm{~kW} \\
\text { PV } \\
\text { System }\end{array}$} & \multirow[b]{2}{*}{$\begin{array}{c}\text { Incentives and SRECs } \\
\text { available }\end{array}$} & \multirow[b]{2}{*}{$\begin{array}{l}\text { SRECI } \\
\text { PBI } \\
\text { contract } \\
\text { (years) }\end{array}$} & \multicolumn{3}{|c|}{ Nominal LCOEG } & \multicolumn{2}{|c|}{$\begin{array}{l}\text { Commercial } \\
\text { average retail } \\
\text { rate ( } \phi / \mathbf{k W h}) \\
\end{array}$} \\
\hline & & & $\begin{array}{l}\text { Third- } \\
\text { party } \\
\text { owned/ } \\
\text { PPA } \\
\text { (\$/kWh) }\end{array}$ & $\begin{array}{c}\text { Self- } \\
\text { financed } \\
\text { with cash } \\
\text { (no debt) } \\
\text { ( } / \text { /kWh) }\end{array}$ & $\begin{array}{c}\text { Net benefit } \\
\text { of third- } \\
\text { party PPA } \\
\text { over cash } \\
(\phi / \mathrm{kWh} \text { and } \\
\%)\end{array}$ & Aug-08 & $\begin{array}{l}\text { Year- } \\
\text { to-date } \\
\text { through } \\
\text { Oct-08 }\end{array}$ \\
\hline \multirow{2}{*}{ CA } & $\begin{array}{l}\text { CSI PBI contract for } \\
\$ 260 / M W h \text { (commercial } \\
\text { ownership) }\end{array}$ & 5 & 33.8 & & \multirow{2}{*}{$0.5(1.5 \%)$} & \multirow{2}{*}{15.2} & \multirow{2}{*}{13.1} \\
\hline & $\begin{array}{l}\text { CSI PBI contract for } \\
\$ 370 / \mathrm{MWh} \text { (federal } \\
\text { agencies) }\end{array}$ & 5 & & 34.3 & & & \\
\hline $\mathrm{CO}$ & $\begin{array}{l}\text { Xcel } \$ 200,000 \text { up front, } \\
\text { assumed } \$ 235 / \mathrm{MWh} \text { for } \\
\text { SRECs }\end{array}$ & 20 & 16.2 & 23.1 & $6.9(40 \%)$ & 9.6 & 8.7 \\
\hline \multirow{3}{*}{ NJ } & $\begin{array}{l}\text { CORE (now closed) }(\$ 2 / \mathrm{W} \\
\text { private sector, } \$ 2.30 / \mathrm{W} \\
\text { public sector), SREC } \\
\text { contract for } \$ 220 / \mathrm{MWh}\end{array}$ & 10 & 21.7 & 27.5 & $5.8(27 \%)$ & \multirow{3}{*}{16.5} & \multirow{3}{*}{14.9} \\
\hline & $\begin{array}{l}\text { PSE\&G loan floor: } \\
\text { \$475/MWh for entire } \\
\text { contract }\end{array}$ & 15 & 9.6 & 16.5 & $6.9(72 \%)$ & & \\
\hline & $\begin{array}{l}\text { SREC trading assumed at } \\
\text { \$654/MWh (avg SREC } \\
\text { cap) }\end{array}$ & 8 & 14.7 & 22.1 & $7.4(50 \%)$ & & \\
\hline
\end{tabular}

\subsubsection{Benefit of Third-Party Ownership/PPA Financing}

The third-party ownership model results in a lower price of energy than the self-financed model because of the federal tax benefits available to commercially owned PV systems. For a federal agency the savings from contracting with a third-party developer (compared to self-financing) can be significant (as is the case in all three locations examined).

First, consider the direct benefit of third-party financing. Under all the scenarios considered for Colorado and New Jersey, contracting with a third-party developer leads to an LCOEG that is approximately $\$ 0.06$ to $\$ 0.07 / \mathrm{kWh}$ cheaper than that of self-financing the PV system (no debt). Note that cash incentive levels for the public and private sectors are roughly the same under these programs. In California, however, the performance-based incentive offered to governments is nearly 1.5 times that offered to private-sector developers. The greater cash incentive awarded to the federal government cancels out some of the net benefit of contracting with a third-party 
developer. The impact of financial structure and available incentives for a $500-\mathrm{kW}$ system is summarized in Table 9.

The LCOEG for California is relatively greater than for Colorado or New Jersey. This is likely a result of the California PBI being available for only 5 years, compared to longer periods for SREC payments in the other two states. In general, the longer the period during which a project's revenues, incentives, and costs are levelized, the lower the levelized price will be.

Table 9 also shows the average retail electricity rate for the year 2008 that customers in different states must pay. This represents the approximate price that a customer will consider (i.e. their current electricity rates) and compare to the levelized price of PV. The LCOEG in California is approximately 2.6 times that of the state's average retail rate for commercial customers. In Colorado, the LCOEG is 1.9 times the average retail electricity rate under the third-party owned/PPA and 2.6 times the average retail electricity rate under the cash model. In New Jersey, both the PSE\&G loan and the SREC price cap cases have LCOEGs that are below the average retail rate if financed by a third-party developer. When self-financed the LCOEG is between 1.1 and 1.8 times greater than the average retail rate. Therefore, it appears that developing projects in New Jersey generally is the most advantageous.

\subsubsection{The Importance of Federal Tax Incentives}

As mentioned, the price paid by a federal agency seems to be less when using a third-party developer, compared to owning the project itself. In part, this is because of the ability to take advantage of federal tax credits. Taxable entities can take advantage of two federal tax incentives, the 30\% ITC for solar and a 5-year modified accelerated depreciation schedule (MACRS). Although federal agencies do not have to pay taxes in the first place, if the benefit of these tax credits exceeds the actual taxes paid, then it would be advantageous to partner with commercial entities.

For federal PV projects developed under the third-party ownership model, federal tax incentives bring down the price of electric generation significantly, as shown in Table 10. Combined, the federal tax incentives reduce project LCOEG by $38 \%$ as compared to a project that receives no tax credits and uses a 20 -year straight-line depreciation schedule. Receiving the $30 \%$ ITC brings down price on a dollar-for-dollar basis, reducing project LCOEG by 30\%. A 5-year MACRS depreciation schedule also is quite advantageous relative to a typical 20-year straight-line schedule (that might otherwise be used by a commercial developer if solar was not eligible for 5year MACRS). Price recovery through accelerated income tax deduction reduces the LCOEG of the sample projects by $8 \%$.

\subsubsection{The Importance of Cash Incentives}

Incentives for solar vary across states, therefore the impact of state and utility cash incentives varies significantly. The analysis shown in Table 10 and described below assumes that available federal tax incentives already are applied to the third-party ownership models. Therefore the third-party comparison is between the LCOEG with federal tax incentives and that also including the cash incentives. For self-financed PV systems, however, the comparison is between the base level LCOEG and that with cash incentives. 
Only Colorado's Xcel Energy currently offers up-front rebates for large systems (500-kW and greater). The $\$ 200,000$ up-front rebate (equivalent to $\$ 0.40 / \mathrm{W}$ for a $500-\mathrm{kW}$ system) reduces the LCOEG by about $\$ 0.03 / \mathrm{kWh}$ - for both third-party owned systems and federal agency selffinanced systems. The 2007 CORE rebates in New Jersey were more valuable, as they brought down LCOEG by $\$ 0.18 / \mathrm{kWh}$ in the case of a third-party owned system (receiving $\$ 2.00 / \mathrm{W}$ for a $500-\mathrm{kW}$ system) and $\$ 0.19 / \mathrm{kWh}$ in the case of federally self-financed systems (receiving $\$ 2.30 / \mathrm{W})$. The performance-based incentive in California is a payment of $\$ 0.26 / \mathrm{kWh}$ for privatesector developers and $\$ 0.37 / \mathrm{kWh}$ for public-sector developers awarded for five years. These payments reduce LCOEG by $\$ 0.11 / \mathrm{kWh}$ under the PPA model (after federal tax credits are applied), and by $\$ 0.16 / \mathrm{kWh}$ for a self-financed system.

When state, utility, and federal incentives were included for a federal agency contracting with a third-party developer, the LCOEG was reduced by 54\% in California, $42 \%$ in Colorado, and $58 \%$ in New Jersey (under the 2007 CORE rebates). When the same projects are self financed, state and utility incentives (because they are not eligible for federal tax credits) reduce LCOEG by $31 \%$ in California, $5 \%$ in Colorado, and 30\% in New Jersey.

\subsubsection{The Importance of SREC Revenue}

SREC revenue is important for projects in Colorado and New Jersey, where utilities are obligated to meet solar set-asides. In Table 10, the SREC results are incremental to both the federal tax credits (for third-party owned systems) and for cash incentives. In Colorado, Xcel locks into 20-year contracts for SRECs with customer-sited projects through an RFP process. With an assumed contract price of $\$ 235 / \mathrm{MWh}$ for 20 years, LCOEG is reduced by $\$ 0.27 / \mathrm{kWh}$ under both financing structures. Long-term contracts for SRECs provide a constant stream of revenue for the project, bringing down the LCOEG significantly.

The three cases analyzed in New Jersey all assume different REC market conditions and contract lengths. Under the CORE program, projects could sell SRECs to NJ Clean Energy for a period of 10 years at the market price. Assuming 10 years of SREC revenue at an average price of $\$ 220 / \mathrm{MWh}$, a project's LCOEG was reduced by $\$ 0.16 / \mathrm{kWh}$ under both financing structures.

The PSE\&G Loan program sets a floor price for SRECs at $\$ 475 / \mathrm{MWh}$ for projects in the program. Under the contract term of 15 years, this reduces LCOEG by $\$ 0.47 / \mathrm{kWh}$. The SRECcap program is more uncertain as to how it will impact revenue streams. The SREC prices modeled here are not projections of the future - rather they are presented as indicators of the relative contribution of SRECs at these high prices, to establish an upper-bound case for reducing the LCOEG. The SREC-cap program was approximated by using the alternative compliance payment cap for 8 years. Such a contract reduces LCOEG by $\$ 0.42 / \mathrm{kWh}$. If achievable, SREC prices on the order of those modeled in this analysis would make the two SREC-only programs much more advantageous than the up-front grants.

\subsubsection{Comparison of LCOEG With and Without Incentives and SREC Revenue}

When combined, the cash incentives, tax credits, and SRECs create significant savings. Under the third-party ownership model, available incentives and revenues reduce LCOEG by $54 \%$ in California, by $78 \%$ in Colorado, by $76 \%$ for the New Jersey CORE program, by $89 \%$ for the PSE\&G Solar Loan, and by $84 \%$ for New Jersey's SREC-cap program. When PV systems are self-financed, cash incentives and SREC revenues reduce LCOEG by $31 \%$ in California, by $57 \%$ 
in Colorado, by $56 \%$ for the New Jersey CORE program, by $74 \%$ for the PSE\&G Solar Loan, and by $65 \%$ for New Jersey's SREC-cap program.

Values of nominal LCOEG and the percentage decreases from baseline LCOEG are laid out in Table 10. Note that these cases do not include the value of reduced electricity purchases from a customer's utility, which can contribute to a customer's decision to move forward with a project. $^{46}$

Table 10. Comparison of LCOEG With and Without Incentives, for a 500 kW System

\begin{tabular}{|c|c|c|c|c|c|}
\hline \multicolumn{2}{|r|}{500 kW PV system } & \multicolumn{4}{|c|}{$\begin{array}{c}\text { Nominal LCOEG ( } \phi / k W h)(\% \text { decrease from baseline } \\
\text { LCOEG) }\end{array}$} \\
\hline State & Incentives available & $\begin{array}{l}\text { Without } \\
\text { incentives }\end{array}$ & $\begin{array}{c}\text { With federal } \\
\text { tax } \\
\text { incentives }\end{array}$ & $\begin{array}{l}\text { With state } \\
\text { incentives }\end{array}$ & $\begin{array}{c}\text { With state } \\
\text { incentives } \\
\text { and SREC } \\
\text { revenues }\end{array}$ \\
\hline \multicolumn{6}{|c|}{ Third-party owned with a PPA } \\
\hline CA & CSI PBI contract for $\$ 260 / \mathrm{MWh}$ for 5 years & 72.9 & $45.0(38 \%)$ & $30.4(54 \%)$ & \\
\hline $\mathrm{CO}$ & $\begin{array}{l}\text { Xcel } \$ 200,000 \text { up front, assumed } \$ 235 / \mathrm{MWh} \\
\text { for SRECs for } 20 \text { years }\end{array}$ & 74.3 & $46.3(38 \%)$ & $39.9(42 \%)$ & $12.8(78 \%)$ \\
\hline \multirow{3}{*}{ NJ } & $\begin{array}{l}\text { CORE (now closed) } \$ 2 / \mathrm{W} \text {, SREC contract for } \\
\$ 220 / \mathrm{MWh} \text { for } 10 \text { years }\end{array}$ & 90.5 & $56.3(38 \%)$ & $34.1(58 \%)$ & $17.6(76 \%)$ \\
\hline & PSE\&G loan floor: $\$ 475 / \mathrm{MWh}$ for 15 years & 90.5 & $56.3(38 \%)$ & & $5.5(89 \%)$ \\
\hline & $\begin{array}{l}\text { SREC trading assumed at \$654/MWh for } 8 \\
\text { years (avg SREC cap) }\end{array}$ & 90.5 & $56.3(38 \%)$ & & $10.6(84 \%)$ \\
\hline \multicolumn{6}{|c|}{ Self-financed with cash (no debt) } \\
\hline $\mathrm{CA}$ & CSI PBI contract for $\$ 370 / \mathrm{MWh}$ for 5 years & 50.1 & & $34.3(31 \%)$ & \\
\hline $\mathrm{CO}$ & $\begin{array}{l}\text { Xcel } \$ 200,000 \text { up front, assumed } \$ 235 / \mathrm{MWh} \\
\text { for SRECs for } 20 \text { years }\end{array}$ & 53.1 & & $50.2(5 \%)$ & $23.1(57 \%)$ \\
\hline \multirow{3}{*}{ NJ } & $\begin{array}{l}\text { CORE (now closed) } \$ 2.30 / \mathrm{W}, \text { SREC contract } \\
\text { for } \$ 220 / \mathrm{MWh} \text { for } 10 \text { years }\end{array}$ & 63 & & $43.8(30 \%)$ & $27.5(56 \%)$ \\
\hline & PSE\&G loan floor: $\$ 475 / \mathrm{MWh}$ for 15 years & 63 & & $63(0 \%)$ & $16.5(74 \%)$ \\
\hline & $\begin{array}{l}\text { SREC trading assumed at \$654/MWh for } 8 \\
\text { years (avg SREC cap) }\end{array}$ & 63 & & $63(0 \%)$ & $22.1(65 \%)$ \\
\hline
\end{tabular}

\subsubsection{Impact of Debt}

Under the self-financed model, two sets of projects were evaluated to examine the impact of debt on the project, one without debt and one with $60 \%$ debt. It was found that debt fraction did not alter LCOEG significantly. The difference between $0 \%$ and $60 \%$ debt in the scenarios was between $\$ 0.01$ and $\$ 0.03 / \mathrm{kWh}$. Because of this minimal difference only the $0 \%$ debt scenarios are presented in the tables above.

\footnotetext{
${ }^{46}$ This was not included because the point of this analysis is to compare the relative impact of incentives on reducing the LCOEG, and to compare different financing structures for a variety of geographic locations. In analyzing the actual LCOEG for a project, the electric utility-bill savings should be calculated and included in the analysis.
} 


\subsubsection{Final 500-kW PV Analysis Results}

Figure 10 simultaneously shows (1) the differences in LCOEG between financing structures; (2) the relative value of each component's ability to reduce the LCOEG; and (3) geographic differences' effect on financing PV. The height of the entire bar represents the LCOEG of the project, not including any incentives; the bottom black bar for each case represents the final LCOEG, including all of the revenues and incentives. The relative reduction of the LCOEG by each component is represented by the bar height of each incentive, and each incentive is applied only to applicable cases.

First, consider the differences between the financing structures. The total relative level of the LCOEG without incentives (the total bar) is significantly higher for the third-party ownership/PPA model. As explained previously, the total installed cost $(\$ / \mathrm{W})$ generally is the same $^{47}$ for both third-party ownership and the self-financed model (as shown in Table 6). Even though total installed cost does not contribute to the difference in LCOEG, there are several items that federal agencies do not have to pay (but which third-party investors must pay), including federal and state taxes, insurance, and state sales tax.

Second, Figure 10 and Table 10 show that tax credits and cash incentives are critical to reducing the high up-front cost of solar PV. The final LCOEGs, after all incentives have been applied (solid black bars at the bottom), are less for the third-party ownership/PPA model than for selffinanced projects. The reason is that the relative value of state or utility cash incentives and federal tax incentives (ITC and MACRS) is greater than the cash benefits available for federally owned projects. In other words, although the third-party investors must pay more, the sum of the benefits seems to be greater than the benefits provided directly to federal agencies (at least for these generic projects).

The third aspect clearly shown in Figure 10 is the geographic differences between the values of incentives, SREC prices, and also the final LCOEG. Embedded in this comparison are differences in installed costs and solar resource. In general, it appears that it could be most advantageous to develop solar PV in New Jersey; in reality that will depend on future SREC market prices. The 8- to 15-year time horizon in New Jersey and the 20 -year time horizon in Colorado result in much lower LCOEG that the short, 5-year timeframe in California. Finally, because the debt fraction did not alter the LCOEG significantly, New Jersey shows only the nodebt cases for self-financed PV. Colorado has the lowest LCOEG, thanks to the substantial SREC prices for a period of 20 years. Again, the short 5-year timeframe in California appears to not have as great an impact as that of the longer-term SREC prices in New Jersey and Colorado.

\footnotetext{
${ }^{47}$ The one exception is for states that do not have sales tax exemptions for renewable equipment, such as California. The total installed cost for a California project therefore differs, depending on whether the owner is a federal agency or a private, third-party investor.
} 


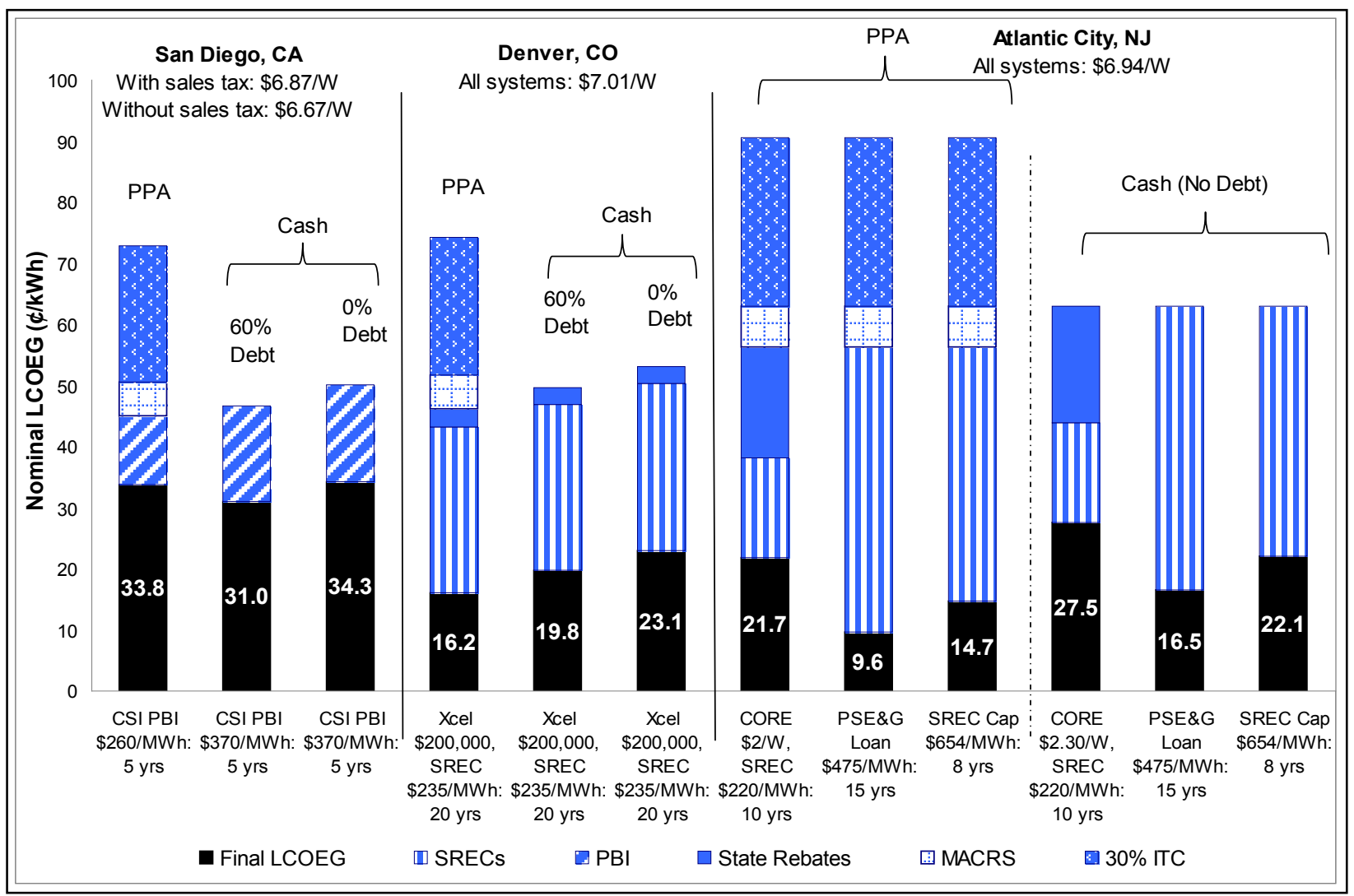

Figure 10. The LCOEG of $500 \mathrm{~kW}$ projects for federal agencies using different financial structures and incentives

This chart shows the LCOEG of 500-kW projects for federal agencies using different financial structures and incentives. Installed costs were the same for each location except California, for which the sales tax was removed for self-financed systems owned by federal agencies. The name of each case designates: Who provides the incentives, the level of any applicable up-front incentives (in $\$ / \mathrm{W}$ or $\$$ ), any SREC payments or PBI payments (in $\$ / \mathrm{MWh}$ ), and the number of years of REC contracts or PBI payments. The NJ SREC Cap incentive uses the average SACP price $-\$ 654 / \mathrm{MW}-$ over the course of 8 years.

\subsubsection{The Utility Third-Party Investor}

The Emergency Economic Stabilization Act of 2008 extends the solar ITC to utilities. Therefore, under the third-party ownership/PPA model, some utilities might choose to be the tax-equity investor. Duke Energy, for example, is interested in owning up to $20 \mathrm{MW}$ of customer-sited PV systems to help it meet its solar RPS and to gain experience with distributed generation. [136] Now that utilities can capture the federal ITC incentives and their regulated rate of return, investing in solar might be more attractive to more utilities.

In Figure 11, the LCOEG of a federal PV system in Colorado is modeled under three financing structures: third-party developer owned, utility owned, and self-financed. It is important to note that, to isolate the differences in financing terms, this analysis ignores the value of cash incentives and SREC payments. The utility investor is comparable to the third-party developer, 
except that the utility's rate of return is regulated by the state's public utility commission. Taxequity investors can take advantage of the 30\% ITC and 5-year MACRS. The baseline LCOEG for these two cases assumes that the developers depreciate equipment using a 20-year straightline depreciation schedule. The difference between the LCOEG for the third-party developer and the utility investor is based solely on the rate of return that the investors receive.

Assuming an 8\% IRR for a third-party developer, LCOEG after absorbing the federal tax incentives is $\$ 0.43 / \mathrm{kWh}$. At the utility's regulated rate of return of $11 \%$ (an approximate assumption for a U.S. utility), LCOEG after federal tax incentives is more than $\$ 0.10$ more at $\$ 0.54 / \mathrm{kWh}$. The two tax-investor cases also are compared to a self-financed system in Figure 11. Interestingly, the tax benefits of solar result in a reduced LCOEG with an $8 \%$ rate of return. At the utility's $11 \%$ IRR, the LCOEG is about the same as the self-financed model, even after the federal tax benefits are absorbed.

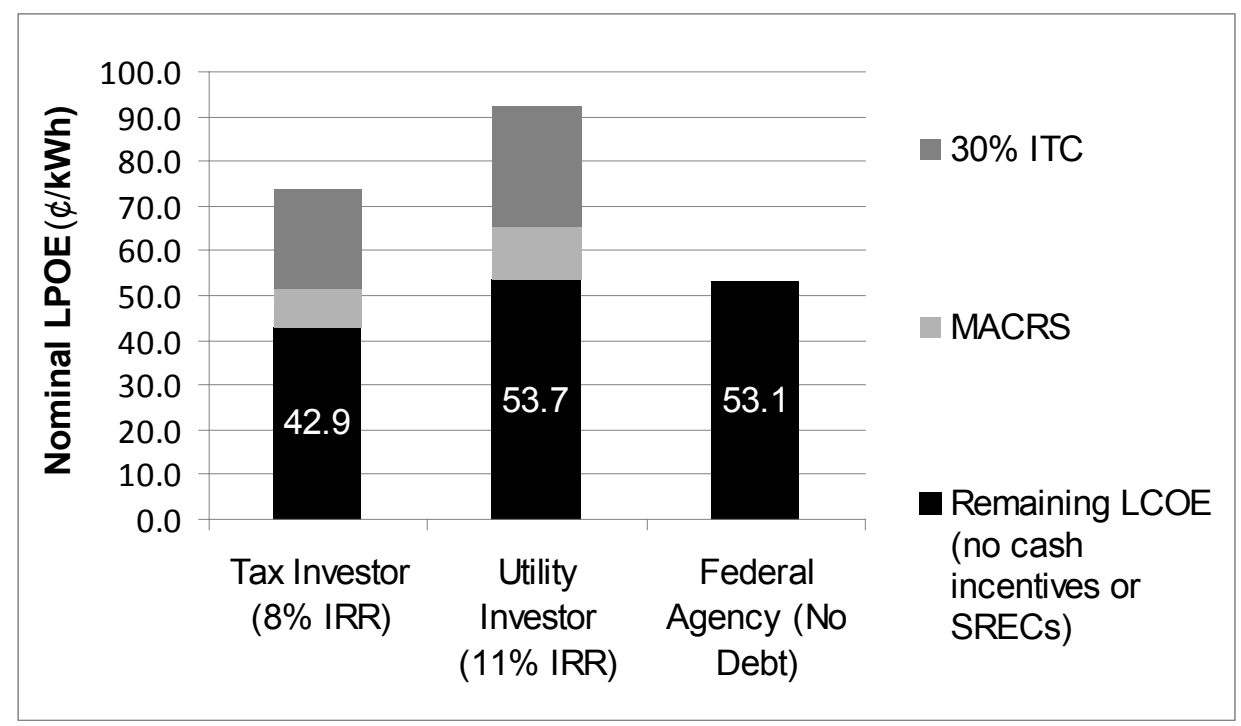

Figure 11. LCOEG after federal tax incentives for a $\mathbf{5 0 0} \mathrm{kW}$ system in Colorado

\subsubsection{LCOEG of a 100-kW System}

Next is a consideration of a 100-kW roof-mounted PV system installed in San Diego, Denver, or Atlantic City. Smaller systems cost more per watt to install because the larger installations can achieve economies of scale. To make up for this, states and utilities usually provide smaller systems with greater incentives than those for large PV projects. The LCOEG of a 100-kW system, however, is considerably more than for a 500-kW, even with the incentives and SREC payments. Regardless, the incentives analyzed in this study are quite valuable for small PV projects overall. The levelized cost of electricity generation of all the incentive programs modeled for a 100-kW PV system is shown in Table 11. 
Table 11. LCOEG Comparison of Financing Structures and Average Retail Rate

\begin{tabular}{|c|c|c|c|c|c|c|c|}
\hline \multirow[b]{2}{*}{$\begin{array}{l}100 \mathrm{~kW} \\
\text { PV } \\
\text { system }\end{array}$} & \multirow[b]{2}{*}{$\begin{array}{c}\text { Incentives and SRECs } \\
\text { available }\end{array}$} & \multirow[b]{2}{*}{$\begin{array}{l}\text { SRECI } \\
\text { PBI } \\
\text { contract } \\
\text { (years) }\end{array}$} & \multicolumn{3}{|c|}{ Nominal LCOEG } & \multicolumn{2}{|c|}{$\begin{array}{l}\text { Commercial } \\
\text { average retail } \\
\text { rate ( } \phi / \mathrm{kWh}) \\
\end{array}$} \\
\hline & & & $\begin{array}{l}\text { Third- } \\
\text { party } \\
\text { owned/ } \\
\text { PPA } \\
\text { (ф/kWh) }\end{array}$ & $\begin{array}{c}\text { Self- } \\
\text { financed } \\
\text { with cash } \\
\text { (no debt) } \\
\text { (ф/kWh) }\end{array}$ & $\begin{array}{l}\text { Net benefit } \\
\text { of third-party } \\
\text { PPA over } \\
\text { cash }(\phi / k W h \\
\text { and } \%)\end{array}$ & $\begin{array}{c}\text { Aug- } \\
08\end{array}$ & $\begin{array}{l}\text { Year-to- } \\
\text { date } \\
\text { thru } \\
\text { Oct-08 }\end{array}$ \\
\hline \multirow{2}{*}{$\mathrm{CA}$} & $\begin{array}{l}\text { CSI PBI contract for } \\
\text { \$260/MWh (commercial } \\
\text { ownership) }\end{array}$ & 5 & 40.2 & & \multirow{2}{*}{$1.3(3 \%)$} & \multirow{2}{*}{15.2} & \multirow{2}{*}{13.1} \\
\hline & $\begin{array}{l}\text { CSI PBI contract for } \\
\$ 370 / \mathrm{MWh} \text { (federal } \\
\text { agencies) }\end{array}$ & 5 & & 41.5 & & & \\
\hline $\mathrm{CO}$ & $\begin{array}{l}\text { Xcel \$2/watt and an } \\
\text { SREC contract for } \\
\$ 115 / \text { MWh for } 20 \text { years }\end{array}$ & 20 & 25.3 & 35.6 & $10.3(41 \%)$ & 9.6 & 8.7 \\
\hline \multirow{3}{*}{ NJ } & $\begin{array}{l}\text { CORE (now closed) } \\
\text { (\$2.25/W private sector, } \\
\$ 2.50 / \mathrm{W} \text { public sector), } \\
\text { SREC contract for } \\
\$ 220 / \mathrm{MWh}\end{array}$ & 10 & 33.2 & 41.4 & $8.2(25 \%)$ & \multirow{3}{*}{16.5} & \multirow{3}{*}{14.9} \\
\hline & $\begin{array}{l}\text { PSE\&G loan floor: } \\
\$ 475 / \mathrm{MWh} \text { for entire } \\
\text { contract }\end{array}$ & 15 & 23.8 & 32.6 & $8.8(37 \%)$ & & \\
\hline & $\begin{array}{l}\text { SREC trading assumed } \\
\text { at } \$ 654 / \mathrm{MWh} \text { (avg SREC } \\
\text { cap) }\end{array}$ & 8 & 28.9 & 38.1 & $9.2(32 \%)$ & & \\
\hline
\end{tabular}

Source for commercial average retail electricity rates: EIA 2008 Electric Power Monthly with data for October 2008.

\subsubsection{Benefit of Third-Party Ownership/PPA Financing}

As noted, for a 100-kW system the third-party ownership model results in a reduced price of energy (Table 11). ${ }^{48}$ In Colorado and New Jersey-where each state's incentives and SREC revenues are close to identical for the public and private sectors - the third-party ownership model has a net benefit of approximately $\$ 0.08$ to $\$ 0.10 / \mathrm{kWh}$ over the self-financed model. In California, where private-sector developers receive \$260/MWh and public-sector developers receive $\$ 370 / \mathrm{MWh}$, the net benefit of the third-party ownership model is only $\$ 0.01 / \mathrm{kWh}$. Again, the shorter period in California is part of the reason for a lower overall benefit.

For a $100-\mathrm{kW}$ system, LCOEG can be as much as four times the average commercial retail electricity rate. Table 11 shows these comparisons between retail utility rates and project LCOEG. It appears that developing projects in New Jersey under the third-party ownership model is the most advantageous.

\footnotetext{
${ }^{48}$ There is some question as to whether an installer would be interested in using the third-party ownership model for a system that is only $100 \mathrm{~kW}$ in size. This example therefore might be relevant only for agencies willing to install several 100-kW systems_- perhaps on several buildings on a campus or located relatively near to each other. This analysis did not attempt to quantify the minimum size of a PV project that would be required for developers to consider using the third-party financing model.
} 


\subsubsection{The Importance of Federal Tax Incentives}

As with $500-\mathrm{kW}$ systems, the tax benefit of PV captured by third-party developers is quite valuable for smaller systems. The federal ITC and MACRS tax incentives combine to reduce LCOEG by $38 \%$ compared to $100-\mathrm{kW}$ projects developed with 20 -year straight-line depreciation alone. Results are shown in Table 12.

\subsubsection{The Importance of Cash Incentives}

After federal tax credits were incorporated, cash incentives were explored. As shown in Table 12 , these were layered upon the federal tax incentive benefits for the third-party ownership model. Up-front incentives or rebates can reduce the price for a small project significantly. Colorado's $\$ 2.00 / \mathrm{W}$ incentive (or $\$ 200,000$ ) reduces a $100-\mathrm{kW}$ system's LCOEG by $\$ 0.16 / \mathrm{kWh}$, compared to the price with only federal tax credits for the third-party owned system. For selffinanced systems the LCOEG is reduced by $\$ 0.15 / \mathrm{kWh}$. For systems larger than $100-\mathrm{kW}$, the upfront incentive is capped at $\$ 200,000$ - so the larger the project, the lower the resulting dollarper-watt incentive. Comparing the two projects, the 100-kW rebate reduced LCOEG by $\$ 0.15 / \mathrm{kW}$ to $\$ 0.16 / \mathrm{kWh}$, but the same monetary award to a $500-\mathrm{kW}$ system only reduced LCOEG by $\$ 0.03 / \mathrm{kWh}$ (for both third-party owned and self-financed).

New Jersey's CORE rebate $(\$ 2.25 / \mathrm{W}$ for the private sector and $\$ 2.50 / \mathrm{W}$ for the public sector) brings down LCOEG by $\$ 0.21 / \mathrm{kWh}$. Again, this is for both the self-financed systems as well as third-party owned systems (which already incorporated federal tax credits).

California awards $100-\mathrm{kW}$ systems the same performance-based incentives that $500-\mathrm{kW}$ systems receive. Thus, the reduction of LCOEG in terms of cents per kilowatt-hour is the same$\$ 0.11 / \mathrm{kWh}$ for third-party owned systems with federal tax incentives and $\$ 0.16 / \mathrm{kWh}$ for selffinanced systems. The performance-based incentive, however, is less valuable on a percentage basis for 100-kW systems.

\subsubsection{The Importance of SREC Revenues}

Lastly, the SREC value was layered upon the federal tax credits and any available cash incentives. The SREC revenues were assumed to be equally valuable for $100-\mathrm{kW}$ systems as for $500-\mathrm{kW}$ systems. The only difference is in Colorado, where Xcel has established a predetermined SREC price for systems of up to $100 \mathrm{~kW}(\$ 115 / \mathrm{MWh})$. Larger projects bid into a utility procurement process, which means that the SREC price could be greater or less than for systems up to $100 \mathrm{~kW}$. In this analysis, the $\$ 115 / \mathrm{MWh}$ for $100-\mathrm{kW}$ systems is less than the assumed \$235/MWh contract for the 500-kW system.

\subsubsection{Comparison of LCOEG With and Without Incentives and SREC Revenue}

The inclusion of all available federal tax credits, cash incentives and SREC revenues dramatically reduces the overall cost of $100-\mathrm{kW}$ PV systems. Compared to the up-front cost without them, all available incentives and revenues reduce project LCOEG for 100-kW systems by between $52 \%$ and $79 \%$ under the third-party ownership model, and by between $27 \%$ and $59 \%$ for the self-financed model. On a percentage basis, this is less than the benefit of incentives and revenues for larger systems, due to the economies of scale reached by larger systems.

Under the third-party ownership model, available incentives and revenues reduce LCOEG by $52 \%$ in California, by $71 \%$ in Colorado, by $71 \%$ for the New Jersey CORE program, by $79 \%$ for 
the PSE\&G Solar Loan, and by 75\% for New Jersey's SREC-cap program. When PV systems are self-financed, the cash incentives combined with SREC revenues reduce LCOEG by $27 \%$ in California, by $44 \%$ in Colorado, by $48 \%$ for the New Jersey CORE program, by $59 \%$ for the PSE\&G Solar Loan, and by 52\% for New Jersey's SREC-cap program. Values of nominal LCOEG and the percentage decreases from baseline LCOEG are laid out in Table 12.

Table 12. Comparison of LCOEG With and Without Incentives for a $100 \mathrm{~kW}$ System

\begin{tabular}{|c|c|c|c|c|c|}
\hline \multicolumn{2}{|r|}{100 kW PV system } & \multicolumn{4}{|c|}{ Nominal LCOEG ( $\phi / k W h)$ ( $\%$ decrease from Baseline LCOEG) } \\
\hline State & Incentives available & $\begin{array}{c}\text { Without } \\
\text { incentives }\end{array}$ & $\begin{array}{l}\text { With federal } \\
\text { tax incentives }\end{array}$ & $\begin{array}{l}\text { With state } \\
\text { incentives }\end{array}$ & $\begin{array}{c}\text { With state } \\
\text { incentives and } \\
\text { SREC revenues }\end{array}$ \\
\hline \multicolumn{6}{|c|}{ Third-party owned with a PPA } \\
\hline $\mathrm{CA}$ & $\begin{array}{l}\text { CSI PBI contract for \$260/MWh for } 5 \\
\text { years }\end{array}$ & 84.1 & $51.5(38 \%)$ & $40.2(52 \%)$ & \\
\hline $\mathrm{CO}$ & $\begin{array}{l}\text { Xcel } \$ 2 / \text { watt and an SREC contract } \\
\text { for } \$ 115 / \mathrm{MWh} \text { for } 20 \text { years }\end{array}$ & 87.6 & $54.4(38 \%)$ & $38.6(56 \%)$ & $25.3(71 \%)$ \\
\hline \multirow{3}{*}{ NJ } & $\begin{array}{l}\text { CORE (now closed) } \$ 2.25 / \mathrm{W} \text {, SREC } \\
\text { contract for } \$ 220 / \mathrm{MWh} \text { for } 10 \text { years }\end{array}$ & 114 & $70.4(38 \%)$ & $49.7(56 \%)$ & $33.2(71 \%)$ \\
\hline & $\begin{array}{l}\text { PSE\&G loan floor: \$475/MWh for } 15 \\
\text { years }\end{array}$ & 114 & $70.4(38 \%)$ & & $23.8(79 \%)$ \\
\hline & $\begin{array}{l}\text { SREC trading assumed at } \$ 654 / \mathrm{MWh} \\
\text { for } 8 \text { years (avg SREC cap) }\end{array}$ & 114 & $70.4(38 \%)$ & & $28.9(75 \%)$ \\
\hline \multicolumn{6}{|c|}{ Self-financed with cash (no debt) } \\
\hline $\mathrm{CA}$ & $\begin{array}{l}\text { CSI PBI contract for } \$ 370 / \mathrm{MWh} \text { for } 5 \\
\text { years }\end{array}$ & 57.3 & & $41.5(27 \%)$ & \\
\hline $\mathrm{CO}$ & $\begin{array}{l}\text { Xcel } \$ 2 / \text { watt and an SREC contract } \\
\text { for } \$ 115 / \mathrm{MWh} \text { for } 20 \text { years }\end{array}$ & 63.5 & & $48.8(23 \%)$ & $35.6(44 \%)$ \\
\hline \multirow{3}{*}{ NJ } & $\begin{array}{l}\text { CORE (now closed) } \$ 2.50 / \mathrm{W} \text {, SREC } \\
\text { contract for } \$ 220 / \mathrm{MWh} \text { for } 10 \text { years }\end{array}$ & 79.1 & & $57.8(27 \%)$ & $41.4(48 \%)$ \\
\hline & $\begin{array}{l}\text { PSE\&G loan floor: \$475/MWh for } 15 \\
\text { years }\end{array}$ & 79.1 & & $79.1(0 \%)$ & $32.6(59 \%)$ \\
\hline & $\begin{array}{l}\text { SREC trading assumed at } \$ 654 / \mathrm{MWh} \\
\text { for } 8 \text { years (avg SREC cap) }\end{array}$ & 79.1 & & $79.1(0 \%)$ & $38.1(52 \%)$ \\
\hline
\end{tabular}

\subsubsection{Final 100-kW PV Analysis Results}

Figure 10 simultaneously shows the differences in LCOEG between financing structures; the relative value of each component's ability to reduce the LCOEG; and the geographic differences of financing PV. In general, the overall pattern of results identified for the 500-kW PV system appears to hold for the smaller 100-kW system.

The third-party investor's ability to capture federal tax incentives results in a lower LCOEG than that of the cash-financed models (Table 12, Figure 10). Federal tax credits, cash incentives, and SREC revenues are critical to reducing the high up-front cost of solar PV. The PSE\&G Solar Loan program in New Jersey resulted in the lowest LCOEG, because it sets a floor SREC price over 15 years - a long period. In contrast, the 5-year California PBI provides an important benefit, but appears to be less effective than the SREC prices in Colorado or New Jersey.

When the self-financed structures are compared to each other the benefits of cash incentives and SREC revenues become clear for federal agencies. Colorado has the lowest LCOEG due to the substantial SREC prices offered for a period of 20 years. Again, the short 5-year timeframe in 
California's structure appears to have less impact than the longer-term SREC prices used in New Jersey and Colorado.

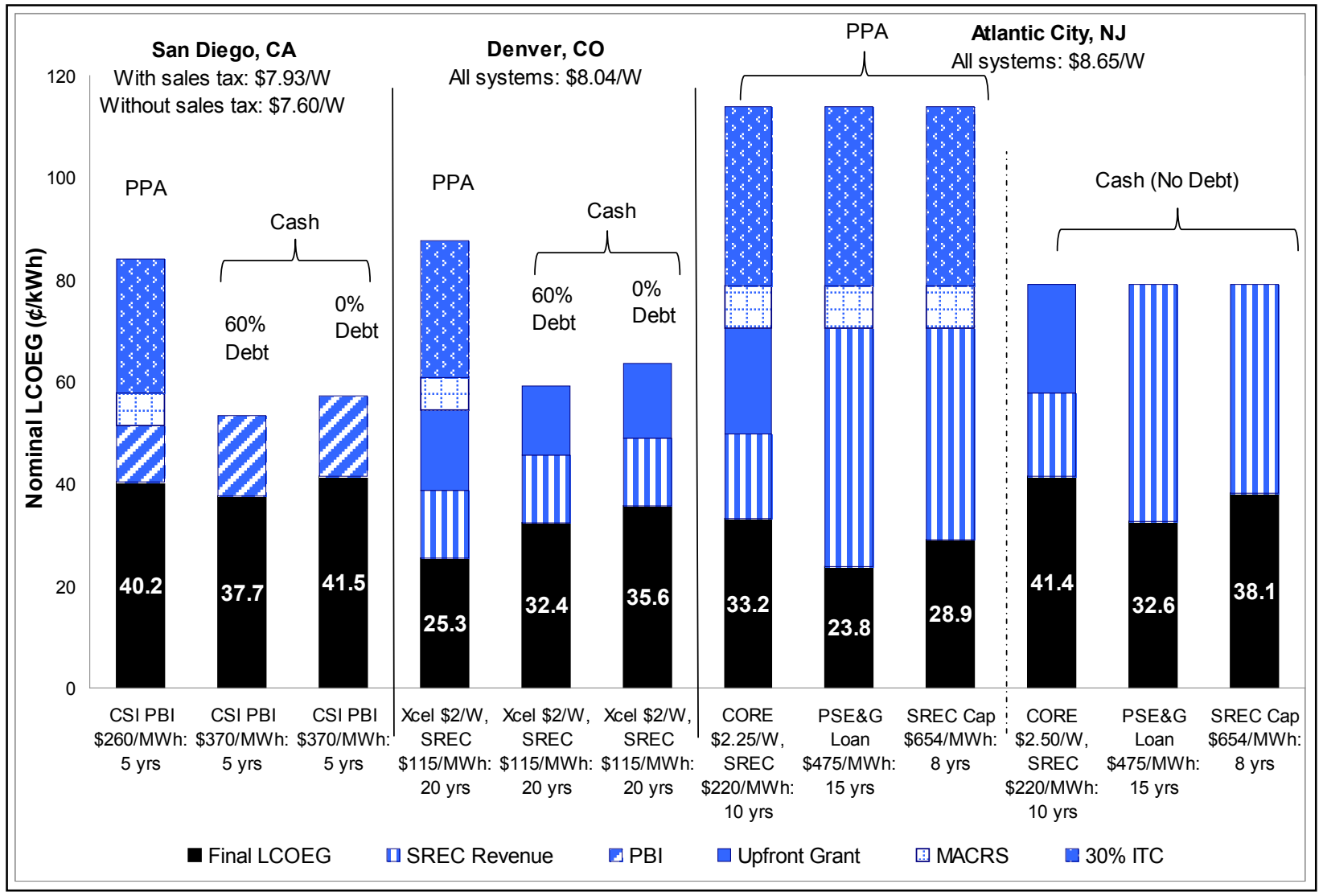

Figure 12. The LCOEG of $100 \mathrm{~kW}$ projects for federal agencies using different financial structures and incentives

Figure 12 shows the LCOEG of 100-kW projects under different financial structures and incentives. Installed costs under the PPA and loan models are not different-except in California, because the estimates for installed cost include sales tax, and federal agencies do not have to pay sales tax. The name of each case designates who provides the incentives, the level of any up-front incentives (in \$/W), any SREC payments or PBI payments (in $\$ / \mathrm{MWh}$ ), and the number of years of REC contracts or PBI payments. The NJ SREC Cap incentive uses the average SACP price $(\$ 654 / \mathrm{MWh})$ over the course of 8 years.

\subsection{Federal PV System Analysis Conclusions}

This analysis explores the role that financial incentives and investment models play in determining the levelized cost of a PV system for a federal agency. Overall, the financial incentives offered in New Jersey result in the lowest LCOEG, followed by Colorado and then California. There are three main reasons why this generic analysis resulted in higher LCOEG for California. First, the PBI incentives are only available for a period of 5 years. The longer 8- to 20-year time horizons in New Jersey and Colorado enable the project price to be levelized over a longer period, and thus reduced. Second, California has established aggressive incentive reductions. At 
points when a predetermined amount of installed capacity has signed up for the PBI, the incentive payment level is lessened. Currently, California is ahead of schedule in stepping down its PBI payments. Finally, California does not allow for RECs to be traded separately from renewable power generation; they must remain bundled. The value of the SREC revenue stream in Colorado and New Jersey appear to be quite valuable, however, mainly because both states have a solar set-aside in their RPS policies. It is apparent that contract length and whether the price is negotiated, fixed, or based on the market price are expected to have a significant impact on LCOEG.

Overall, it appears that the third-party ownership/PPA model is cheaper than either the cash or loan models because of all the tax incentives that can be captured by a third-party developer. The benefit of the PPA model over the cash model is more definite in Colorado and New Jersey than it is in California. Most noticeably, the two current New Jersey incentives (PSE\&G Solar Loan and SREC-cap program) resulted in the largest net benefits for a $500-\mathrm{kW}$ system. Although the analysis presented here can give a rough estimate of relative values of incentives and financing structures, it is important for project developers and federal agencies to do their own LCOEG calculations to ensure the capturing all of the site-specific characteristics of a project, as well as currently available incentives. 


\section{Conclusions}

The options for financing PV projects on federal buildings and land have expanded in recent years. Several market forces have converged to make the economics of PV projects attractive to federal agencies - including substantial decreases in the cost of PV, increased federal tax credits, and increased state incentives. Together these factors have driven an increased amount of capital towards development of new PV projects, especially in the federal sector. Federal agencies also have an increased interest in deploying on-site renewable generation to meet various federal goals and mandates. The combination of increased demand and increased supply has resulted in substantial innovation in the options for financing PV projects on federal property. As explored in this report, each method has its own advantages and challenges.

The federal government has established a number of goals and mandates that both encourage and require reductions in energy intensity and a greater use of renewable electricity. Most federal agencies therefore are evaluating strategies for deploying PV on public property. Payback periods are longer than most public entities consider reasonable, so state incentive programs and RPS policies have proven critical in supporting additional PV deployment. Appropriate policies and adequate financial incentives can motivate federal agencies to consider implementing PV on their sites. One goal of this report is to gauge the progress of federal sector PV deployment throughout the country, determine what policies and programs are working, and identify barriers to deployment. Several examples are presented that highlight the success of federal PV deployment, and which explain how these projects utilize a number of incentives, revenue streams, and financial incentives. It is hoped that other federal agencies can learn from the examples and successfully deploy their own projects.

A significant source of funding for PV on public and private buildings comes from state incentives and policies. In most states, a federal PV installation sized to meet the average load on-site can receive credit on its utility bill for excess generation sent to the grid, through net metering. Other cash incentives - many of which are funded by SBC programs - are enacted on a state-by-state or utility-specific basis, and federal agencies often are eligible for up-front rebates or production-based incentives to reduce the cost of PV systems. Much of the success of the PV financing structures depends directly on the availability of state and federal cash and tax incentives (described in Section 5). Unless a PV system is paid for in cash (through a line-item appropriation or that year's energy conservation project budget), these incentives can be critical components to making the economics of a PV project work. It therefore could be challenging to deploy PV in states without these incentives and still achieve the necessary payback. As shown for California, these incentives can be critical to making the payback period acceptable for federal projects.

The use of RECs has emerged as an important revenue stream for deploying renewables. The environmental attributes of renewable energy generation are captured in this tradable commodity and are critical to the success of many PV projects. SRECs provide the most revenue in states having specific RPS set-asides for solar (which does not include California). In Colorado, Xcel Energy purchases SRECs from the owners of qualified PV systems, in addition to providing an up-front cash rebate. Now that New Jersey has phased out up-front rebates for all but residential customers, developers must depend solely on SREC sales to utilities to finance any projects. The 
elimination of the up-front solar rebate could create additional financing hurdles for new PV projects, particularly for small projects.

Energy-efficiency measures can be a critical component when considering PV deployment. In addition to supporting mandated reductions in energy intensity under EISA 2007, energy efficiency can reduce the overall payback period of PV when both elements are bundled together. Additionally, if less electricity is used on-site, then deployment of PV can provide a much greater percentage of the site's electricity.

In states that provide significant support for PV, federal entities recently have been able to use the third-party ownership/PPA structure to monetize federal (and sometimes state) tax credits. Given their non-taxpayer status, government agencies traditionally are unable to benefit from the generous federal tax incentives for PV such as the ITC and accelerated depreciation. Under a third-party ownership/PPA structure, however, the public entity hosts rather than owns the PV system. The host secures stable and predictable electricity prices over a 20- to 25-year period. The up-front capital investment and the ongoing operations and maintenance requirements of the $\mathrm{PV}$ system are transferred to the tax investor and developer, respectively, in exchange for the tax-credit benefits. As a result, the third-party ownership/PPA model offers great promise to those federal agencies looking to install a significant number of PV systems in the most costefficient manner, especially because it can be used in conjunction with performance contracting. Third-party ownership is not necessarily the solution for all public entities, especially because it requires the ability to sign long-term contracts (up to 20 years in duration). However, proposed laws could extend all federal procurement up to at least 20 years, if not 30 . This financial model is also not the right solution for federal agencies that want to reduce annual electricity bills by taking immediate ownership of the PV system, or for those agencies which are reluctant to give third parties access to their facilities.

One unique innovation with the third-party ownership/PPA financing structure was developed by WAPA in partnership with NREL. For federal agencies operating within WAPA's footprint (slightly larger than its service territory) and which are limited to signing procurement contracts of 10 years, WAPA is willing to act as a contractual intermediary with the PV project developer and sign a PPA for 20 years. This critical role enables federal agencies to deploy PV on-site, when they otherwise might not have been able to do so. Potentially, other power marketing administrations or the Defense Energy Support Center also could play this intermediary role for federal agencies.

The ESPCs and UESCs used by federal agencies have helped save significant energy through improved efficiency and conservation. Super ESPCs are particularly attractive; by establishing the general parameters of any contract agreement and prequalifying a select number of capable ESCOs, the DOE has made it considerably easier for any federal agency to access ESPCs quickly. Recently, these programs also have included deployment of on-site renewables, typically through a subcontractor to the ESCO. As the third-party ownership/PPA model becomes more common in the marketplace it is being used in conjunction with ESPCs, under an ESA, to take advantage of the best elements of each structure (e.g., no capital outlay for the federal agency, a predetermined electricity price, better PV financing terms and payback). 
Overall, there are a number of opportunities for federal agencies to deploy and finance PV systems. With the right combination of incentives, revenues, and financing structures, the federal government is positioned to play a leading role in deploying renewable energy. Bringing together all the necessary elements and contracting authorities is a complex process, however, and requires both creativity and persistence. Despite the challenges, several federal agencies have shown that PV successfully can be deployed on federal property. 


\section{References}

1. U.S. Department of Energy, Assistant Secretary, Energy Efficiency and Renewable Energy, Federal Energy Management Program. Annual Report to Congress on Federal Government Energy Management and Conservation Programs, Fiscal Year 2006.

http://www1.eere.energy.gov/femp/pdfs/annrep06.pdf. Accessed June 9, 2009.

2. Ibid., 72, Table A-2.

3. Ibid., 1.

4. Ibid., 2.

5. Ibid., 3-4, Figure 1 and Figure 2.

6. Ibid., 5.

7. Ibid., 16, Table 4.

8. U.S. Department of Energy, Office of Energy Efficiency and Renewable Energy, Federal Energy Management Program. "2007 FEMP Renewable Energy Requirement Guidance for EPAct 2005 and EO 13423." http://www1.eere.energy.gov/femp/pdfs/ epact05 fedrenewenergyguid.pdf, at 12. Accessed June 9, 2009.

9. Energy Independence and Security Act of $2007 \S 431$. http://frwebgate.access.gpo.gov/cgibin/getdoc.cgi?dbname=110 cong bills\&docid=f:h6enr.txt.pdf. Accessed June 9, 2009.

10. Ibid., 2.

11. "Energy Independence and Security Act (EISA) of 2007: New and Enhanced FEMP Responsibilities." Public Law No. 110-140 (H.R. 6). http://www1.eere.energy.gov/femp/ pdfs/eisa femp.pdf. Accessed June 9, 2009.

12. U.S. Department of Energy, Office of Energy Efficiency and Renewable Energy, Federal Energy Management Program. Annual Report to Congress on Federal Government Energy Management and Conservation Programs, Fiscal Year 2006. http://wwwl.eere.energy.gov/ femp/pdfs/annrep06.pdf, at 16. Accessed June 9, 2009.

13. U.S. Department of Energy, Office of Energy Efficiency and Renewable Energy, Federal Energy Management Program. 2007 Buildings Energy Data Book. "Department of Energy Building Program, Chapter 1.4: Federal Agency Progress toward the Renewable Energy Goal." http://buildingsdatabook.eren.doe.gov/docs\%5CDataBooks\%5C2007_BEDB.pdf . Accessed June 22, 2009.

14. U.S. Department of Energy, Office of Energy Efficiency and Renewable Energy, Federal Energy Management Program. Annual Report to Congress on Federal Government Energy Management and Conservation Programs, Fiscal Year 2006. Table 4, at 16. http://www1.eere.energy.gov/femp/pdfs/annrep06.pdf. Accessed June 9, 2009. 
15. Ibid., 18.

16. U.S. Department of Defense, Office of the Deputy Under Secretary of Defense; Installations and Environment. Annual Energy Management Report, Fiscal Year 2007; January 2008. http://www.acq.osd.mil/ie/energy/energymgmt_report/fy07/DoD-Narrative-Final.pdf. Accessed June 9, 2009.

17. 10 U.S.C. $§$ 2911. U.S. Department of Energy, Office of Energy Efficiency and Renewable Energy, Federal Energy Management Program. "National Defense Authorization Act 2007Energy Performance Goals and Plan for Department of Defense," at. 2.

http://www1.eere.energy.gov/femp/ pdfs/ndaa_2007.pdf. Accessed June 9, 2009.

18. U.S. Department of Defense. FY 2007 Energy Management Performance Summary. http://www.acq.osd.mil/ie/energy/energymgmt_report/fy07/DataSummary_A1.pdf. Accessed June 23, 2009.

19. U.S. Department of Defense. Annual Energy Management Report-2007.

http://www.acq.osd.mil/ie/Energy/energymgmt_report/fy07/DoD-Narrative-Final.pdf, at 28. Accessed June 9, 2009.

20. U.S. Department of Energy, Office of Energy Efficiency and Renewable Energy, Web site, under "TEAM Initiative"; "About the Initiative." http://www1.eere.energy.gov/team/about.html. Accessed June 9, 2009.

21. U.S. Department of Energy. "Order: DOE O 430.2B. Departmental Energy, Renewable Energy, and Transportation Management. Approved February 27, 2008."

http://www.directives.doe.gov/pdfs/doe/doetext/neword/430/o4302b.pdf. Accessed June 9, 2009.

22. U.S. Department of Energy, Office of Energy Efficiency and Renewable Energy. "The Department of Energy's Transformational Energy Action Management (TEAM) Initiative: Renewables, DOE Renewable Energy Forum." Presentation by Steve Chuslo. February 12, 2008. http://www1.eere.energy.gov/femp/pdfs/re forum_team.pdf. Accessed June 9, 2009.

23. Ibid.

24. Ibid.

25. U.S. Department of Energy, Office of Energy Efficiency and Renewable Energy, Web site, under "TEAM Initiative"; “About the Initiative." http://www1.eere.energy.gov/team/about.html. Accessed June 9, 2009.

26. Solar Energy Industry Association and Prometheus Institute for Sustainable Development. U.S. Solar Industry Year in Review: 2008, released March 19, 2009. http://www.seia.org/galleries/pdf/2008 Year_in_Review-small.pdf.

27. Wiser, R.; Barbose, G.; Peterman, C. Tracking the Sun: The Installed Cost of Photovoltaics in the United States from 1998-2007. Lawrence Berkley National Laboratory. http://eetd.lbl.gov/ea/emp/reports/lbnl-1516e.pdf. Accessed June 9, 2009. 
28. U.S. Department of Energy, Office of Energy Efficiency and Renewable Energy, Federal Energy Management Program. Utility Incentives Legislative Summary, revised July 2000. http://www1.eere.energy.gov/femp/pdfs/incent_2.pdf. Accessed June 9, 2009.

29. "Public Benefit Funds for Renewable Energy,” Database of State Incentives for Renewables and Efficiency (DSIRE).

http://www.dsireusa.org/incentives/allsummaries.cfm?Sector=State_Sector\&SearchType=PBF\& $\underline{\& \mathrm{re}=1 \& \text { ee }=1}$ Accessed June 22, 2009.

30. U.S. Department of Energy, Office of Energy Efficiency and Renewable Energy. "State Energy Alternatives: System Benefit Charges.” No longer available online DOE Web site.

31. Interstate Renewable Energy Council and North Carolina Solar Center. "Public Benefit Funds for Renewables (Estimated Funding).” http://www.dsireusa.org/documents/ summarymaps/PBF_Map.ppt. Accessed June 22, 2009.

32. Nutter, S.; and Wilson, S. Massachusetts Technology Collaborative (state agency that administers the Massachusetts Renewable Energy Trust). Personal communication. December 2008 and June 2009.

33. Garrison, C. Honeywell. NJ Clean Energy Fund. Personal communication. December 2008.

34. Dooley, K. Energy Resource Research, NYSERDA. Personal communication. December 2008.

35. Khight, P. U.S. EPA, Facilities Manager, Western Ecology Division. Personal communication. December 2008.

36. PowerLight Corporation. 2004. Case Study: U.S. Postal Service, West Sacramento, California.

37. U.S. Department of Energy, Office of Energy Efficiency and Renewable Energy. "FEMP Focus-Summer 2004: U.S. Postal Service Sacramento Facilities Undergoing Comprehensive Energy Retrofits." DOE/EERE/FEMP, News and Events. http://www1.eere.energy.gov/femp/ newsevents/fempfocus_article.cfm/news id=7423. Accessed June 27, 2008.

38. Powerlight Corporation. 2004. Case Study: U.S. Postal Service, West Sacramento, California.

39. Bird, L.; Dagher, L.; and Swezey, B. Green Power Marketing in the United States: A Status Report (10th ed.). NREL/TP-670-42502. Golden, CO: National Renewable Energy Laboratory. December 2007. http://www.nrel.gov/docs/fy08osti/42502.pdf. Accessed June 9, 2009.

40. Intel News Release. "Intel Becomes Largest Purchaser of Green Power in the U.S." January 28, 2008. http://www.intel.com/pressroom/archive/releases/20080128corp.htm. Accessed June 9, 2009. 
41. Pepsico News Release. "Pepsico Makes Largest Corporate Purchase of Renewable Energy Certificates." April 30, 2007. http://phx.corporate-ir.net/phoenix.zhtml?c=78265\&p=irolnewsArticle\&ID=992341. Accessed June 9, 2009.

42. New Jersey Clean Energy Program. "SREC Pricing," New Jersey's Clean Energy Program Web site. ". http://www.njcleanenergy.com/renewable-energy/programs/solar-renewable-energycertificates-srec/pricing/pricing. Accessed June 22, 2009.

43. Parker, S. "Maryland Expands RPS: 1,500 MW Solar by 2022." Renewable Energy Access. April 12, 2007. http://www.renewableenergyaccess.com/rea/news/story?id=48102. Accessed June 10, 2009.

44. Wiser, R.; Barbose, G. Renewables Portfolio Standards in the United States: A Status Report with Data Through 2007. LBNL-154E. Lawrence Berkeley National Laboratory, April 2008. http://eetd.lbl.gov/ea/EMS/reports/lbnl-154e.pdf. Accessed June 10, 2009.

45. Barbose, G. Staff Research Associate, Lawrence Berkeley National Laboratory. Personal communication. February 6, 2009.

46. 3 Phases Energy Services. "Selling Solar with RECs." Presentation at the 2007 California Solar Forum. http://www.californiasolarcenter.org/pdfs/forum/2007.1.31_SolarForum_TDerrick3PhasesEnergy_SellingSolarRECs.pdf. January 31, 2007. Accessed June 10, 2009.

47. Cory, K.; Coughlin, J.; Jenkin, T.; Pater, J.; Swezey, B. Innovations in Wind and Solar PV Financing. NREL/TP-670-42919. Golden, CO: National Renewable Energy Laboratory, February 2008. http:/www.nrel.gov/docs/fy08osti/42919.pdf. Accessed June 10, 2009.

48. Gilliam, R. "Capitalizing on Incentives for On-site Renewables: The Solar PPA Model." Presentation by SunEdison to the EPA. http://epa.gov/climateleaders/documents/events/ dec2007/Rock_Gilliam.pdf. Accessed June 10, 2009.

49. U.S. General Services Administration. News Release. "Denver Federal Center to Build Solar Park." August 3, 2007. http://www.sunedison.com/uploads/pr/27/080207-gsa.pdf/. Accessed June 23, 2009.

50. U.S. General Service Administration; Denver Federal Center. "Denver Federal Center Solar Park."

http://www.gsa.gov/Portal/gsa/ep/contentView.do?contentType=GSA_OVERVIEW\&contentId= 24515. Accessed June 23, 2008.

51. Xcel Energy. "Solar*Rewards." http://www.xcelenergy.com/RESIDENTIAL/RENEWABLEENERGY/SOLAR_REWARDS/Pa ges/home.aspx. Accessed June 23,2009. 
52. U.S. General Service Administration. "Reducing Government Building Operating Costs Through Innovation and Efficiency." Statement of David Winstead before Committee on Environment and Public Works, March 28, 2007. http://www.gsa.gov/Portal/gsa/ep/ contentView.do? noc $=T \&$ content Type $=$ GSA BASIC\&contentId $=23118$. Accessed June $10,2009$.

53. Emergency Economic Stabilization Act of 2008, Public Law No. 110-343, signed by the President October 3. http://www.govtrack.us/congress/bill.xpd?bill=h110-1424. Accessed June 10, 2009.

54. Bolinger, M. Financing Non-Residential Photovoltaic Projects: Options and Implications. LBNL-1410E. Lawrence Berkeley National Laboratory, January 2009. http://eetd.lbl.gov/ea/ EMS/reports/lbnl-1410e.pdf. Accessed June 10, 2009.

55. U.S. Department of Treasury. "Implementing the American Recovery and Reinvestment Act of 2009 (Recovery Act)." http://www.ustreas.gov/recovery/programs.shtml. Accessed June 10, 2009.

56. Solar Energy Industries Association. Guide to Federal Tax Incentives for Solar Energy: Version 2.0. October 7, 2008.

57. U.S. Internal Revenue Service. "A Brief Overview of Depreciation.” http://www.irs.gov/ businesses/small/article/0,id=137026,00.html. Accessed June 10, 2009.

58. "Modified Accelerated Cost-Recovery System (MACRS) + Bonus Depreciation," Database of State Incentives for Renewables and Efficiency (DSIRE) (reviewed February 27, 2008). http://www.dsireusa.org/library/includes/incentive2.cfm? Incentive Code $=$ US06F\&State=Federal \&currentpageid=1. Accessed June 10, 2009.

59. U.S. Internal Revenue Service. "Chapter 4. Figuring Depreciation Under MACRS," Internal Revenue Service Publication 946. http://www.irs.gov/publications/p946/ch04.html. Accessed March 2008.

60.ESA08. Economic Stimulus Act, Public Law No. 110-185 § 103.

http://www.govtrack.us/congress/bill.xpd?bill=h110-5140. Accessed June 10, 2009.

61. Solar Energy Industries Association. "Key Provisions Benefiting the Solar Energy Industry in the American Recovery and Reinvestment Act." http://seia.org/galleries/pdf/ exec_summary_of final_bill_2 17 09.pdf. Accessed June 10, 2009.

62. Ibid.

63. Database of State Incentives for Renewables and Efficiency (DSIRE). "Corporate Tax Incentives for Renewable Energy." (Last review varies by state.) http://www.dsireusa.org/incentives/allsummaries.cfm?State=US\&ImplementingSector=F\&Searc hType $=$ Corporate \&re $=1 \&$ ee $=0$ Accessed June 22, 2009. 
64. U.S. Department of Energy, Office of Energy Efficiency and Renewable Energy. "EERE State Partnerships and Activities: State Energy Alternatives: Tax Incentives." No longer available on EERE Web site.

65. Database of State Incentives for Renewables and Efficiency (DSIRE). "Glossary, Financial Incentives: Corporate Tax Incentives.” http://www.dsireusa.org/glossary/. Accessed June 10, 2009.

66. Ibid.

67. Database of State Incentives for Renewables and Efficiency (DSIRE). "Sales Tax Incentives for Renewable Energy." http://www.dsireusa.org/library/includes/type.cfm?EE=0\&RE=1. Accessed June 10, 2009.

68. Database of State Incentives for Renewables and Efficiency (DSIRE). "Glossary, Financial Incentives: Production Incentives.” http://www.dsireusa.org/glossary/. Accessed June 10, 2009.

69. Database of State Incentives for Renewables and Efficiency (DSIRE). "Oregon: Business Energy Tax Credit." http://www.dsireusa.org/library/includes/ incentivesearch.cfm? Incentive Code=OR03F\&Search=Type\&type=Corporate \&CurrentPageID $=$ $\underline{2 \& E E=1 \& R E=1}$. Accessed January 25, 2009.

70. Oregon Department of Energy, Conservation Division. "Business Energy Tax Credits." http://www.oregon.gov/ENERGY/RENEW/Solar/Support-BETC.shtml. Accessed June 10, 2009.

71. Oregon Department of Energy, Conservation Division. "Business Energy Tax Credit PassThrough.” http://egov.oregon.gov/ENERGY/CONS/BUS/tax/pass-through.shtml. Accessed June $10,2009$.

72. Colello, J. Pass-Through Program Manager, Oregon Department of Energy, Conservation Division. Personal communication. June 20, 2008.

73. Oregon Department of Energy, Conservation Division. "Case Study: North Santiam School District: Homework pays off for North Santiam Schools.” http://egov.oregon.gov/ENERGY/ CONS/SB1149/Schools/docs/NorthSantiam.PDF. Accessed June 10, 2009.

74. PowerLight Corporation. "Case Study: Marina Mail Processing Center, Marina del Rey, California." No longer available on the web.

75. Ibid.

76. FEMP: Distributed Energy Resources Case Study. "Photovoltaic DER System Could Save USPS \$25,000 per Year in Marina del Rey, California.” November 2002.

http://www.nrel.gov/docs/fy03osti/31847.pdf. Accessed June 10, 2009.

77. Ibid. 
78. Guice, J.; King, J. 2007. Solar Power Services: How PPAs are Changing the PV Value Chain. Greentech Media Inc.

79. Department of Energy. 2001. Greening Federal Facilities: An Energy, Environmental, and Economic Resource Guide for Federal Facility Managers and Designer. Second Edition. NREL Subcontract No. AAR-0-29469-01. DOE Prime Contract No. DE-AC36-99G010337. Available online at: http://www.eere.energy.gov/femp/pdfs/29267-0.pdf. Accessed July 1, 2009.

80. U.S. Department of Energy, Office of Energy Efficiency and Renewable Energy. 2009.

"Fenestration." Building Technologies. http://www1.eere.energy.gov/buildings/ commercial/fenestration.html\#U-Factor. Accessed June 10, 2009.

81. Kollins, K.; Cory, K.; Speer, B. Forthcoming 2009. Solar Photovoltaic Financing: Addressing Regulation of Third-Party PPA System Owners. National Renewable Energy Laboratory. Technical Report.

82. Western Area Power Administration. "Nellis AFB Credits Teamwork for Largest PV System in U.S." Reliable Energy Solutions Bulletin; February 2008. http://www.wapa.gov/ES/pubs/esb/ 2008/feb/feb081.htm. Accessed June 10, 2009.

83. Nellis Air Force Base. Press Release. Largest Photovoltaic System Begins Construction at Nellis Air Force Base. April 23, 2007. http://www.mmarenewableventures.com/news/docs/ MMARV\%20Nellis\%20Apr\%2007\%20final.pdf. Accessed June 10, 2009.

84. Nellis Air Force Base. Nellis Activates Nations Largest PV Array, December 18, 2007. http://www.nellis.af.mil/news/story.asp?id=123079933. Accessed June 10, 2009.

85. Western Area Power Administration. "Nellis AFB Credits Teamwork for Largest PV System in U.S." Reliable Energy Solutions Bulletin. February 2008. http://www.wapa.gov/ES/pubs/ esb/2008/feb/feb081.htm. Accessed June 10, 2009.

86. Lamonica, M. “Air Force Base in Nevada Goes Solar with 14-Megawatt Array," CNET News. http://news.cnet.com/8301-11128_3-9829328-54.html. Accessed June 10, 2009.

87. Ibid.

88. Shah, C. National Renewable Energy Laboratory. Personal communication. July 2008.

89. U.S. Department of Energy, Office of Energy Efficiency and Renewable Energy. On-Site Renewable Energy Projects with Innovative Project Financing. News release, August 28, 2007. http://wwwl.eere.energy.gov/femp/news/news_detail.html?news id=11218. Accessed June $10,2009$.

90. Dahle, D. National Renewable Energy Laboratory. Personal communication. February 4, 2009. 
91. U.S. Department of Energy, Office of Energy Efficiency and Renewable Energy. On-Site Renewable Energy Projects with Innovative Project Financing. News release, August 28, 2007. http://www1.eere.energy.gov/femp/news/news detail.html?news id=11218. Accessed June $10,2009$.

92. Levi, M. Energy Program Manager, General Services Administration. Personal communication. August 21, 2008.

93. U.S. Code, Title 10, Subtitle A, Part IV, Chapter 173, Subchapter II, Section 2922a, "Contracts for energy or fuel for military installations" subsection (b). http://www4.law.cornell.edu/uscode/html/uscode10/usc_sec 10_00002922---a000-.html

94. Lenardic, D. "Photovoltaic Systems-Technologies and Applications" (last updated Jan 16, 2008). http://www.pvresources.com/en/top500pv.php . Accessed June 22, 2009.

95. U.S. Department of Energy, Office of Energy Efficiency and Renewable Energy. On-Site Renewable Energy Projects with Innovative Project Financing. News release, August 28, 2007. http://www1.eere.energy.gov/femp/news/news detail.html?news id=11218. Accessed June $10,2009$.

96. Reed, M. "Renewable Energy Generation on Federal Sites." Western Area Power Administration presentation. RRFA webcast, January 17, 2008.

97. Westby, R., Technology Manager, NREL Federal Energy Management Program. Personal communication. December 15, 2008.

98. “Mesa Top Photovoltaic Array Fact Sheet." http://www1.eere.energy.gov/femp/pdfs/ pfs mesatoparray.pdf. Accessed June 10, 2009.

99. NREL news release, October 30, 2007. "Department of Energy's National Renewable Energy Lab to Dramatically Increase Use of Clean, Renewable Energy: New 'Green Building,' Biomass and Solar Facilities to Transform How NREL Uses Power."

http://www.nrel.gov/news/press/2007/534.html. Accessed June 10, 2009.

100. Westby, R, National Renewable Energy Laboratory. Personal communication. December $15,2008$.

101. "Energy Independence and Security Act of 2007: A Summary of Major Provisions." CRS Report for Congress, December 21, 2007. Order Code RL34294.

http://energy.senate.gov/public/ files/RL342941.pdf. Accessed June 10, 2009.

102. Ibid.

103. U.S. Department of Energy, Office of Energy Efficiency and Renewable Energy. "\$2.0 Billion Investment and \$5.8 Billion Energy Cost Savings." Fact Sheet: Federal Energy Management Program: Super ESPC—Just the Facts. http://www1.eere.energy.gov/femp/ pdfs/espc_fact_sheet.pdf. Accessed June 10, 2009. 
104. U.S. Department of Energy. Press Release. DOE Awards Sixteen Contracts for up to $\$ 80$ Billion in Energy Efficiency, Renewable Energy, and Water Conservation Projects at Federal Facilities. December 18, 2008. http://www.energy.gov/news/6804.htm. Accessed June 10, 2009.

105. Anderson, R.; Sullivan, J. “Briefing Paper on Energy Services Companies," World Energy Efficiency Association. No longer available on World Efficiency Association Web site.

106. BP Solar. BP Solar: USMC 29 Palms California. http://www.bp.com/liveassets/ bp internet/solar/bp solar_usa/STAGING/local_assets/downloads pdfs/29PalmsTag.pdf. Accessed June 10, 2009.

107. California Solar Center. "Military Base Upgrades with 1.1 MW Solar Array [Twentynine Palms]." Solar E-Clips. http://www.californiasolarcenter.org/solareclips/2003.02/200302115.html. Accessed June 10, 2009.

108. Anderson, R.; Sullivan, J. “Briefing Paper on Energy Services Companies,” World Energy Efficiency Association. No longer available on WEAA Web site.

109. U.S. Department of Energy, Office of Energy Efficiency and Renewable Energy. "Federal Energy Management Program: Utility Energy Services Contracts." http://www1.eere.energy.gov/femp/financing/uescs.html. Accessed June 10, 2009.

110. Snook, J. "UESC: Utility Energy Service Contracts: Energy Conservation Services from Your Utility Company." Presented at GovEnergy Training Workshop, August 6, New Orleans. http://www.govenergy.com/2007/pdfs/finance/Snook_Finance track_S1.pdf. Accessed June 10, 2009.

111. U.S. Department of Energy, Office of Energy Efficiency and Renewable Energy. "Agreement for Energy Conservation and Demand Side Management Services Agreement for Energy Conservation Between the United States of America and Utility Company." http://www1.eere.energy.gov/femp/docs/civagree.doc. Accessed June 10, 2009.

112. U.S. Department of Energy, Office of Energy Efficiency and Renewable Energy. "Marine Corps Base Camp Pendleton Shares the Keys to Their Successful Energy Program." August 31, 2005. http://www1.eere.energy.gov/femp/news/news detail.html?news id=9358. Accessed June $10,2009$.

113. San Diego Gas and Electric Energy Efficiency Case Study 2008. "Local Military Facility Helps Protect the Planet." http://sdge.com/business/esc/documents/energyshowcase/Pendlton.pdf. Accessed June 22, 2009.

114. U.S. Department of Energy, Office of Energy Efficiency and Renewable Energy. Federal Energy Management Program: You Have the Power. "Energy Projects-Harold Washington Social Security Center.” http://www1.eere.energy.gov/femp/services/yhtp/ energy projects detail.cfm/id=20. Accessed June 10, 2009. 
115. Shirley, L. Project Manager. Social Security Administration, Chicago Regional Office. Personal communication. November 2007.

116. U.S. Department of Energy, Office of Energy Efficiency and Renewable Energy. Federal Energy Management Program: You Have the Power. "Energy Projects-Harold Washington Social Security Center." http://www1.eere.energy.gov/femp/services/yhtp/ energy_projects detail.cfm/id=20. Accessed June 10, 2009.

117. Shirley, L. Project Manager. Social Security Administration, Chicago Regional Office. Personal communication. November 2007.

118. Ibid.

119. Dahle, D. National Renewable Energy Laboratory, Federal Energy Management Program. Personal communication. October 2007.

120. U.S. Department of Energy, Office of Energy Efficiency and Renewable Energy. Program Overview: Federal Energy Management Program: Energy Savings Performance Contract. "Congress and President Encourage Agencies to Use ESPCs." http://www1.eere.energy.gov/ femp/pdfs/espc toolkit.pdf. Accessed June 10, 2009.

121. U.S. Department of Energy, Office of Energy Efficiency and Renewable Energy. Fact Sheet: Federal Energy Management Program: Super ESPC—Just the Facts. "Federal ESPC Projects in 46 States." http://www1.eere.energy.gov/femp/pdfs/espc fact sheet.pdf. Accessed June 10, 2009. "Super ESPC Awarded Delivery Orders Summary." http://www1.eere.energy.gov/femp/pdfs/do_awardedcontracts.pdf. Accessed June 10, 2009.

122. U.S. Department of Energy. "Federal Energy Management Program: FEMP FocusMarch/April 2003"; "Navy Uses Super ESPC to Make Photovoltaic Energy Pay." http://www1.eere.energy.gov/femp/pdfs/fempfocus_mar_apr_2003.pdf. Accessed June 22, 2009.

123. Ibid.

124. Ibid.

125. Ibid.

126. Ibid.

127. U.S. Department of Energy. "Federal Energy Management Program: Department of Energy's Energy Savings Performance Contracts Stretch Budgets at the Bureau of Indian Affairs"; "Overview"; "Project Summary." http://www1.eere.energy.gov/femp/financing/superespcs indianaff.html. Accessed July 1, 2008.

128. Schoch, J. SunEdison, Public Sector Sales Manager. Personal communication. February 2008; Schoch, J. \& Dickey, M. SunEdison. Personal communication. July 2008. 
129. Blair, N.; Mehos, M.; Christensen, C. 2008. "Sensitivity of Concentrating Solar Power trough performance, cost, and financing with the Solar Advisor Model." http://www.nrel.gov/csp/ pdfs/42852.pdf. Accessed June 10, 2009.

130. Osterwald, C.; Adelstein J.; del Cueto, J.; Kroposki, B.; Trudell, D.; Moriarty, T. 2006. Comparison of Degradation Rates of Individual Modules Held at Maximum Power. National Renewable Energy Laboratory. http://www.solarintegrated.com/fileadmin/dateiablage/ media/ScientificPapers/NREL_-_Comparison_of_Degradation_Rates_-_May_2006.pdf. Accessed June 10, 2009.

131. Moore, L.; Post, H.; Hayden, H.; Canada, S.; Narang, D. 2007. "Photovoltaic Power Plant Experience at Arizona Public Service, a 5-Year Assessment." Sandia National Laboratory, 2007.

132. Chuang, J. 2008. "Role of Debt Financing," Panel Discussion. Solar Power Project Development and Finance Tutorial. Infocast, San Francisco, California. July 10-11, 2008.

133. California Public Utilities Commission. 2008. California Solar Initiative Handbook. http://www.gosolarcalifornia.ca.gov/documents/CSI_HANDBOOK.PDF. Accessed June 10, 2009.

134. Available at http://www.njcleanenergy.com/renewable-energy/programs/solar-renewableenergy-certificates-srec/pricing/pricing. Accessed June 10, 2009.

135. Ibid.

136. Duke Energy. Press release. June 9, 2008. "Duke Energy Launches Plan to Own and Operate Solar Power Generation at up to 850 North Carolina Sites." http://www.dukeenergy.com/news/releases/2008060901.asp. Accessed June 10, 2009.

137. Guice, J., King, J. Solar Power Services: How PPAs are Changing the PV Value Chain. Greentech Media Inc. February 14, 2008.

138. National Renewable Energy Laboratory. "PVWATTS: A Performance Calculator for GridConnected PV Systems." http://www.nrel.gov/rredc/pvwatts. Accessed June 11, 2009.

139. National Renewable Energy Laboratory. "Solar Advisor Model (SAM)." https://www.nrel.gov/analysis/sam/. Accessed June 11, 2009.

140. Kandt, A. "Identifying Cost-Effective Renewable Energy Projects." National Renewable Energy Laboratory Presentation to the National Defense Center for Energy and Environment. June 2008.

141. U.S. Department of Energy, Office of Energy Efficiency and Renewable Energy, Federal Energy Management Program. "Federal Renewable Energy Screening Assistant." http://analysis.nrel.gov/fresa/. Accessed June 11, 2009.

142. DSIRE home page. http://www.dsireusa.org/. Accessed June 11, 2009. 
143. Natural Resources Canada. RETScreen home page. http://www.retscreen.net/ang/home.php. Accessed June 11, 2009.

144. Bureau of Land Management. "BLM Initiates Environmental Analysis of Solar Energy Development." Press release. May 8, 2008. http://www.blm.gov/wo/st/en/info/newsroom/ 2008/may_08/NR_053008.html. Accessed June 11, 2009.

145. National Renewable Energy Laboratory. "HOMER.” https://analysis.nrel.gov/homer/. Accessed June 11, 2009.

146. National Renewable Energy Laboratory. "Energy Analysis: Market Analysis Models and Tools." http://www.nrel.gov/analysis/analysis_tools_market.html. Accessed June 11, 2009.

147. Sustainable Building Energy Council. "Energy-10, A Powerful Energy Simulation Tool for Buildings and Homes." http://www.sbicouncil.org/ displaycommon.cfm?an=1\&subarticlenbr=112. Accessed June 11, 2009.

148. Walker, A. National Renewable Energy Laboratory, Personal communication. July 2008; Walker, A. "Renewable Energy Planning: Multiparametric Cost Optimization," Presented at Solar 2008, American Solar Energy Society (ASES), San Diego, CA, May 3-8, 2008. http://www.nrel.gov/docs/fy08osti/42921.pdf. Accessed June 11, 2009.

149. Ibid.

150. Ibid.

151. Walker, A. National Renewable Energy Laboratory. Personal communication. July 2008.

152. "Executive Order 13123 - Greening the Government Through Efficient Energy Management." Federal Register. June 8, 1999. Available at http://www.ofee.gov/eo/ eo13123.pdf. Accessed June 11, 2009.

153. Ibid. § 204.

154. "2007 Buildings Energy Data Book," Chapter 1.4: Federal Agency Progress Toward the Renewable Energy Goal. http://buildingsdatabook.eere.energy.gov/docs\%5CDataBooks\%5C2007_BEDB.pdf. Accessed May 16, 2008.

155. U.S. Department of Energy, Office of Energy Efficiency and Renewable Energy, Federal Energy Management Program. “About the Program: Energy Policy Act of 2005.”No longer available on DOE Web site.

156. “Energy Policy Act of 2005." Public Law No. 109-58. Aug. 8, 2005. Section 203(b)(2). http://www.energy.wsu.edu/ftp-ep/pubs/library/EnergyPolicyAct-PublicLaw109-58.pdf.

Accessed June 11, 2009. 
157. U.S. Department of Energy, Office of Energy Efficiency and Renewable Energy, Federal Energy Management Program. "2007 FEMP Renewable Energy Requirement Guidance for EPAct 2005 and EO 13423,” pg. 9. http://www1.eere.energy.gov/femp/pdfs/ epact05 fedrenewenergyguid.pdf. Accessed June 11, 2009.

158. "Energy Policy Act of 2005," Public Law 109-58. Aug. 8, 2005. Section 204. http://www.energy.wsu.edu/ftp-ep/pubs/library/EnergyPolicyAct-PublicLaw109-58.pdf.

Accessed June 11, 2009.

159. Ibid.

160. "Executive Order 13423: Strengthening Federal Environmental, Energy, and Transportation Management." Federal Register, January 26, 2007. http://www.ofee.gov/eo/EO 13423.pdf. Accessed June 11, 2009.

161. U.S. Department of Energy, Office of Energy Efficiency and Renewable Energy, Federal Energy Management Program. "Laws and Regulations: Executive Order 13423." http://www1.eere.energy.gov/femp/regulations/eo13423.html. Accessed June 20, 2008.

162. Ibid.

163. U.S. Environmental Protection Agency. "Greening EPA: Federal Requirements." http://www.epa.gov/oaintrnt/energy/fedreq.htm. Accessed June 11, 2009.

164. "Energy Independence and Security Act of 2007," Section 431. Enacted December 2007. http://frwebgate.access.gpo.gov/cgibin/getdoc.cgi?dbname=110_cong_bills\&docid=f:h6enr.txt.pdf. Accessed June 24, 2009.

165. Ibid.

166. "Energy Independence and Security Act (EISA) 2007: New and Enhanced FEMP Responsibilities.” Public Law No. 110-140 (H.R.6). March 2008. http://www1.eere.energy.gov/femp/pdfs/eisa femp.pdf. Accessed June 11, 2009.

167. Ibid. $\S 515$.

168. Energy Independence and Security Act 2007, Subtitle C-High Performance Federal Buildings, $\S 432$, paragraph (10), subparagraph (B) Funding Options. http://frwebgate.access.gpo.gov/cgi-bin/ getdoc.cgi?dbname=110 cong_bills\&docid=f:h6enr.txt.pdf. Accessed June 11, 2009.

169. U.S. Department of Energy, Office of Energy Efficiency and Renewable Energy, Federal Energy Management Program. "Annual Report to Congress on Federal Government Energy Management and Conservation Programs, Fiscal Year 2005.” pg. 29. http://www1.eere.energy.gov/femp/pdfs/annrep05.pdf. Accessed June 11, 2009. 
170. U.S. Department of Energy, Office of Energy Efficiency and Renewable Energy, Federal Energy Management Program. "2007 FEMP Renewable Energy Requirement Guidance for EPAct 2005 and EO 13423," pg. 9. http://www1.eere.energy.gov/femp/pdfs/ epact05 fedrenewenergyguid.pdf. Accessed June 11, 2009.

171. Remarks of President Barack Obama promoting the recovery plan with U.S. Department of Energy Secretary Steven Chu. February 2009.

http://www.whitehouse.gov/blog_post/serious_about energy independence/. Accessed June 11, 2009. 


\section{Appendices}

\section{Appendix A. Federal Sector PV Deployment}

Table A-1. Select Examples of Federal Sector PV Deployment, by State and Project

\begin{tabular}{|c|c|c|c|c|c|c|c|c|c|}
\hline State & $\begin{array}{c}\text { Cash } \\
\text { Incentives }\end{array}$ & REC & $\begin{array}{l}\text { Energy } \\
\text { Efficiency }\end{array}$ & PPA & WCI & $\begin{array}{l}\text { ESPC / } \\
\text { SES }\end{array}$ & $\begin{array}{l}\text { Super } \\
\text { ESPC }\end{array}$ & UESC & $\begin{array}{l}\text { Tax } \\
\text { Credits }\end{array}$ \\
\hline \multicolumn{10}{|l|}{ California } \\
\hline $\begin{array}{l}\text { USPS, Sacramento Processing \& } \\
\text { Dist. Center (§ 2.2.4) }\end{array}$ & $\mathrm{x}$ & & $\mathrm{X}$ & & & $\mathrm{x}$ & & & \\
\hline $\begin{array}{l}\text { USPS, Marina Del Ray Processing \& } \\
\text { Dist. Center ( } \$ \text { 5.1.1) }\end{array}$ & $\mathrm{x}$ & & $\mathrm{x}$ & & & & & & \\
\hline $\begin{array}{l}\text { GSA, Sacramento Federal Building } \\
(\S 5.2 .2)\end{array}$ & $\mathrm{x}$ & $\mathrm{x}$ & & $\mathrm{x}$ & & & & & $\mathrm{x}$ \\
\hline $\begin{array}{l}\text { Marine Corps, Twenty-Nine Palms } \\
\text { Compound ( } \S 6.5 .1 .1)\end{array}$ & & & $\mathrm{x}$ & & & $\mathrm{x}$ & & & \\
\hline $\begin{array}{l}\text { Marine Corp, Camp Pendleton } \\
(\S 5.4 .2 .1)\end{array}$ & & & $\mathrm{x}$ & & & $\mathrm{x}$ & & $\mathrm{x}$ & \\
\hline Navy, Coronado Base (§ 5.4.3.1) & & & $\mathrm{x}$ & & & & $\mathrm{X}$ & & \\
\hline $\begin{array}{l}\text { Education, Sherman Indian High } \\
\text { School (§ 5.4.3.2) }\end{array}$ & & & $\mathrm{X}$ & & & & $x$ & & \\
\hline \multicolumn{10}{|l|}{ Colorado } \\
\hline $\begin{array}{l}\text { GSA, Denver Federal Center } \\
(\S 3.3 .3)\end{array}$ & $\mathrm{x}$ & $\mathrm{x}$ & & $\mathrm{x}$ & & & & & $\mathrm{x}$ \\
\hline Army, Fort Carson Base (§ 5.3.1) & & $\mathrm{x}$ & & $\mathrm{x}$ & $\mathrm{x}$ & & & & $\mathrm{x}$ \\
\hline $\begin{array}{l}\text { NREL, Mesa Top PV Project } \\
(\S 5.3 .2)\end{array}$ & $\mathrm{x}$ & $\mathrm{x}$ & $\mathrm{x}$ & $\mathrm{x}$ & $\mathrm{x}$ & $\mathrm{x}$ & & & $\mathrm{x}$ \\
\hline \multicolumn{10}{|l|}{ Illinois } \\
\hline $\begin{array}{l}\text { Social Security Center, Harold } \\
\text { Washington }(\S 5.4 .2 .2)\end{array}$ & & & $\mathrm{X}$ & & & & & $x$ & \\
\hline \multicolumn{10}{|l|}{ Massachusetts } \\
\hline GSA, Trapelo Road facility (§ 2.2.1) & $\mathrm{x}$ & & $\mathrm{x}$ & & & & $\mathrm{x}$ & & \\
\hline \multicolumn{10}{|l|}{ Nevada } \\
\hline Air Force, Nellis Base (§ 5.2.1) & & $\mathrm{x}$ & & $\mathrm{x}$ & & & & & $\mathrm{x}$ \\
\hline \multicolumn{10}{|l|}{ New Jersey } \\
\hline $\begin{array}{l}\text { GSA, Trenton Courthouse Annex } \\
(\S 2.2 .2)\end{array}$ & $\mathrm{x}$ & & & & & & & & \\
\hline \multicolumn{10}{|l|}{ New York } \\
\hline Army, New Windsor Base (§ 2.2.3) & $\mathrm{x}$ & & & & & & & & \\
\hline $\begin{array}{l}\text { National Park Service, Jamaica Bay } \\
\text { Wildlife Refuge (§ 2.2.3) }\end{array}$ & $\mathrm{x}$ & & & & & & & & \\
\hline \multicolumn{10}{|l|}{ Oregon } \\
\hline EPA, Corvallis building ( $(2.2 .4)$ & $\mathrm{x}$ & & & & & & & & \\
\hline $\begin{array}{l}\text { Education, North Santiam School } \\
\text { District }(\S 4.4 .4)\end{array}$ & & & $\mathrm{x}$ & & & & & & $\mathrm{x}$ \\
\hline
\end{tabular}




\section{Appendix B. Federal-Sector Eligibility for Net Metering}

Table B-1. Federal-Sector Eligibility for Net Metering, by State

\begin{tabular}{|c|c|c|c|c|c|}
\hline State & kW Size/Limit & $\begin{array}{l}\text { Net Excess Generation } \\
\text { Compensation Credit Method }\end{array}$ & \begin{tabular}{|c|} 
Inter- \\
connection \\
Standards \\
\end{tabular} & $\begin{array}{c}\text { Statewide } \\
\text { Capacity Limits }\end{array}$ & $\begin{array}{l}\text { Liability } \\
\text { Insurance }\end{array}$ \\
\hline$A Z$ & APS: $100 \mathrm{~kW}$ & $\begin{array}{l}\text { Credited to customer's next bill at } \\
\text { utility's retail rate; granted to utility } \\
\text { at end of calendar year }\end{array}$ & No & $15 \mathrm{MW}$ & N/A \\
\hline AR & \begin{tabular}{|} 
Residential: $25 \mathrm{~kW}$; \\
Commercial: $300 \mathrm{~kW}$
\end{tabular} & $\begin{array}{l}\text { Credited to customer's next bill at } \\
\text { the retail rate; granted to utility at } \\
\text { end of 12-month billing cycle }\end{array}$ & Yes & None & Not specified \\
\hline CT & $2 \mathrm{MW}$ & & Yes & None stated & Yes \\
\hline $\mathrm{DE}$ & $\begin{array}{l}\text { Residential: } 25 \mathrm{~kW} ; \\
\text { Non-residential } \\
\text { (DP\&L): } 2 \text { MW; Non- } \\
\text { residential (DEC) } \\
\text { and municipal } \\
\text { utilities: } 500 \mathrm{~kW} \\
\end{array}$ & $\begin{array}{c}\text { Credited to customer's next bill at } \\
\text { retail rate; at end of 12-month } \\
\text { period any remaining NEG is } \\
\text { granted at the utility's avoided-cost } \\
\text { rate to Delaware's Green Energy } \\
\text { Fund }\end{array}$ & Yes & $\begin{array}{l}1 \% \text { (utilities could } \\
\text { allow a higher limit } \\
\quad \text { or no limit) }\end{array}$ & $\begin{array}{l}\text { Yes (DEC): at } \\
\text { least } \$ 1 \text { million in } \\
\text { liability ins. and } \\
\$ 1 \text { million in } \\
\text { property-loss ins. }\end{array}$ \\
\hline $\mathrm{FL}$ & $2 \mathrm{MW}$ & $\begin{array}{l}\text { Credited to customer's next bill at } \\
\text { retail rate; purchased by utility at } \\
\text { avoided-cost rate at end of } 12- \\
\text { month billing cycle }\end{array}$ & Yes & None stated & $\begin{array}{l}\text { Yes: } 10 \mathrm{~kW}- \\
2 \mathrm{MW}\end{array}$ \\
\hline $\mathrm{HI}$ & $\begin{array}{l}\text { HECO, MECO and } \\
\text { HELCO: } 100 \mathrm{~kW} ; \\
\text { KIUC: } 50 \mathrm{~kW}\end{array}$ & $\begin{array}{c}\text { Credited to customer's next bill; } \\
\text { granted to utility at end of } 12 \text {-month } \\
\text { billing cycle }\end{array}$ & Yes & $\begin{array}{c}1.0 \% \text { of each } \\
\text { utility's peak } \\
\text { demand }\end{array}$ & $\begin{array}{l}\text { Yes (subject to } \\
\text { change) }\end{array}$ \\
\hline ID & $\begin{array}{c}\text { Avista : } 25 \mathrm{~kW} \\
\text { Idaho Power: } 25 \mathrm{~kW} \\
\text { - } 100 \mathrm{~kW} \text { (large } \\
\text { cust.) } \\
\text { Rocky Mountain } \\
\text { Power: } 100 \mathrm{~kW}\end{array}$ & $\begin{array}{l}\text { Credited to customer's next bill at } \\
\text { utility's retail rate for residential and } \\
\text { small commercial customers; } \\
\text { credited at } 85 \% \text { of utility's avoided- } \\
\text { cost rate for all other customers }\end{array}$ & No & $\begin{array}{c}0.1 \% \text { of utility's } \\
2002 \text { peak demand } \\
\text { (in Idaho) }\end{array}$ & Not specified \\
\hline IL & $40 \mathrm{~kW}$ & $\begin{array}{l}\text { Credited to customer's next bill at } \\
\text { utility's retail rate; granted to utility } \\
\text { at end of } 12 \text {-month billing cycle }\end{array}$ & Yes & \begin{tabular}{|c|}
$1 \%$ of the total \\
peak demand \\
supplied by a utility \\
the previous year \\
for net-metered \\
and dual-metered \\
systems $\leq 2 \mathrm{MW}$
\end{tabular} & $\begin{array}{l}\text { S1 MW: No; } \\
>1 \mathrm{MW}: \text { Yes }\end{array}$ \\
\hline KY & $30 \mathrm{~kW}$ & $\begin{array}{c}\text { Credited to customer's next bill (no } \\
\text { expiration) }\end{array}$ & Yes & $\begin{array}{c}1 \% \text { of a utility's } \\
\text { hour peak load } \\
\text { during the previous } \\
\text { year }\end{array}$ & $\begin{array}{l}\text { General liability } \\
\text { coverage } \\
\text { required }\end{array}$ \\
\hline MD & $2 \mathrm{MW}$ & $\begin{array}{l}\text { Credited to customer's next bill at } \\
\text { the retail rate; granted to utility at } \\
\text { end of } 12 \text {-month period with no } \\
\text { compensation for the customer }\end{array}$ & Yes & $1,500 \mathrm{MW}$ & Not specified \\
\hline MA & At capacity $2 \mathrm{MW}$ & $\begin{array}{c}\text { Varies by system type and } \\
\text { customer class }\end{array}$ & Yes & $\begin{array}{c}1 \% \text { of each utility's } \\
\text { peak load }\end{array}$ & No \\
\hline MI & $<30 \mathrm{~kW}$ & $\begin{array}{c}\text { Credited to customer's next bill } \\
\text { (rates vary by utility); granted to } \\
\text { utility at end of } 12 \text {-month billing } \\
\text { cycle }\end{array}$ & Yes & $\begin{array}{l}0.1 \% \text { of a utility's } \\
\text { peak load or } 100 \\
\text { kW (whichever is } \\
\text { greater) }\end{array}$ & $\begin{array}{l}\text { Varies by utility; } \\
\text { could be in } \\
\text { interconnection } \\
\text { agreement }\end{array}$ \\
\hline MO & $100 \mathrm{~kW}$ & $\begin{array}{l}\text { Credited to customer's next bill at } \\
\text { utility's avoided-cost rate; granted } \\
\text { to utility at end of 12-months }\end{array}$ & Yes & $\begin{array}{l}5 \% \text { of a utility's } \\
\text { single-hour peak } \\
\text { load (previous } \\
\text { year) }\end{array}$ & $\begin{array}{c}\leq 10 \mathrm{~kW}: \\
\$ 100,000 \\
>10 \mathrm{~kW}: \$ 1 \\
\text { million }\end{array}$ \\
\hline
\end{tabular}




\begin{tabular}{|c|c|c|c|c|c|}
\hline State & kW Size/Limit & $\begin{array}{c}\text { Net Excess Generation } \\
\text { Compensation Credit Method }\end{array}$ & \begin{tabular}{|c|} 
Inter- \\
connection \\
Standards
\end{tabular} & $\begin{array}{c}\text { Statewide } \\
\text { Capacity Limits }\end{array}$ & $\begin{array}{l}\text { Liability } \\
\text { Insurance }\end{array}$ \\
\hline NE & $25 \mathrm{~kW}$ & $\begin{array}{l}\text { Credited to customer and carried } \\
\text { over monthly at varying rates } \\
\text { depending on season and } \\
\text { technology, accumulated ENG } \\
\text { credits paid to customer at end of } \\
\text { calendar year }\end{array}$ & No & $\begin{array}{c}1 \% \text { of peak annual } \\
\text { demand of retail } \\
\text { customers }\end{array}$ & No \\
\hline $\mathrm{NC}$ & $\begin{array}{l}\text { Residential: } 20 \mathrm{~kW} \text {; } \\
\text { Non- } \\
\text { residential: } 100 \mathrm{~kW}\end{array}$ & $\begin{array}{l}\text { Credited to customer's next bill at } \\
\text { applicable time-of-use rate or less; } \\
\text { granted to utility (annually) at } \\
\text { beginning of each summer }\end{array}$ & Yes & $\begin{array}{c}0.2 \% \text { of each } \\
\text { utility's North } \\
\text { Carolina retail } \\
\text { peak load for the } \\
\text { previous year } \\
\end{array}$ & No \\
\hline $\mathrm{OH}$ & $\begin{array}{c}\text { No specified limit } \\
\text { (but must match } \\
\text { some/all of customer } \\
\text { load) }\end{array}$ & $\begin{array}{c}\text { Credited at utility's unbundled } \\
\text { generation rate to customer's next } \\
\text { bill; customer may request refund } \\
\text { of NEG credits accumulated over a } \\
\text { 12-month period } \\
\end{array}$ & $\begin{array}{c}\text { Three levels } \\
\text { of inter- } \\
\text { connection } \\
\text { standards }\end{array}$ & None specified & $\begin{array}{c}\text { Utilities may not } \\
\text { require additional } \\
\text { liability insurance } \\
\text { beyond proof of } \\
\text { insurance. }\end{array}$ \\
\hline OR & \begin{tabular}{|c|} 
Residential: $25 \mathrm{~kW}$ \\
Non-residential (PGE \\
and Pacific Corp): \\
2 MW. Non- \\
residential \\
munis/coops/utility \\
districts: $25 \mathrm{~kW}$ \\
\end{tabular} & Varies by utility & Yes & $\begin{array}{c}\text { PGE and } \\
\text { PacificCorp: no } \\
\text { limit. Others: } 0.5 \% \\
\text { of utilities' historic } \\
\text { single-hour peak } \\
\text { load }\end{array}$ & No \\
\hline PA & $\begin{array}{l}\text { Resid.: } 50 \mathrm{~kW} \text {; Non- } \\
\text { resid.: } 3 \mathrm{MW} ; \\
\text { Customers with } \\
\text { microgrids or } \\
\text { emergency systems: } \\
5 \mathrm{MW}\end{array}$ & $\begin{array}{l}\text { Credited to customer's next bill at } \\
\text { retail rate; PUC to address } \\
\text { treatment of NEG remaining at end } \\
\text { of } 12 \text {-month period }\end{array}$ & Yes & No limit specified & No \\
\hline SC & $\begin{array}{c}\text { Duke Energy- } \\
\text { Residential: } 20 \mathrm{~kW} \text {; } \\
\text { Non-residential: } \\
100 \mathrm{~kW} \\
\end{array}$ & $\begin{array}{l}\text { Credited to customer's next bill at } \\
\text { applicable time-of-use rate or less; } \\
\text { granted to utility (annually) at } \\
\text { beginning of each summer }\end{array}$ & Yes & $\begin{array}{c}0.2 \% \text { of Duke's SC } \\
\text { peak demand for } \\
\text { the previous year }\end{array}$ & No \\
\hline SC & $\begin{array}{c}\text { Progress Energy- } \\
\text { Residential: } 20 \mathrm{~kW} \text {; } \\
\text { Non-residential: } \\
100 \mathrm{~kW} \\
\end{array}$ & $\begin{array}{l}\text { Credited to customer's next bill at } \\
\text { applicable time-of-use rate or less; } \\
\text { granted to utility (annually) at } \\
\text { beginning of each summer }\end{array}$ & Yes & \begin{tabular}{|c|}
$0.2 \%$ of Progress \\
Energy's peak load \\
for the previous \\
year
\end{tabular} & No \\
\hline UT & $\begin{array}{l}\text { Residential: } 25 \mathrm{~kW} \text {; } \\
\text { Non-residential: } \\
2 \mathrm{MW}\end{array}$ & $\begin{array}{l}\text { Credited to customer's next bill at } \\
\text { utility's retail rate; granted to utility } \\
\text { after } 12 \text { months }\end{array}$ & Yes & $\begin{array}{c}0.1 \% \text { of each } \\
\text { utility's peak } \\
\text { demand in } 2007\end{array}$ & No \\
\hline VT & $\begin{array}{c}250 \mathrm{~kW} \text { (farm } \\
\text { systems and "group } \\
\text { net metering" } \\
\text { systems might be } \\
\text { larger, but might not } \\
\text { net meter) }\end{array}$ & $\begin{array}{l}\text { Credited to customer's next bill at } \\
\text { utility's retail rate; granted to utility } \\
\text { at end of } 12 \text {-month billing cycle }\end{array}$ & Yes & \begin{tabular}{|c|} 
The greater of $2 \%$ \\
of each utility's \\
1996 peak demand \\
or peak demand of \\
recent calendar \\
year
\end{tabular} & No \\
\hline
\end{tabular}

Source: Database of State Incentives for Renewable Energy 


\section{Appendix C. Critical Steps in Executing the Third-party Ownership/PPA Model}

Figure 7 (Section 5.2) shows one variation of how a third-party ownership model can be used to help public entities own renewable projects - many others exist. To execute this model using a PPA or ESA for the power (or SREC), the steps listed below are recommended. These were adapted from a report by GreenTech Media [137] and from conversations with Bob Westby at NREL, who has been actively involved in the PPA negotiations for several NREL PV projects. Although the steps are presented in linear fashion, many are concurrent activities.

\section{Step 1: Identify Potential Location(s)}

Identify the buildings or land on which to install a PV system. In preparation for the next step, it is a good idea to characterize the site(s) being considered for development by gathering and providing detailed information. Characterizing the potential solar resource using PVWatts [138] or the Solar Advisor Model (SAM) [139] also is recommended; site hosts are required to enter longitude and latitude, the PV technology of interest, and the tilt and azimuth angles. It also can be useful to characterize other site-specific characteristics, including potential for shading (e.g., buildings, trees, other structures), distance to nearest substation, overall site load, and average electricity prices paid. Using available information, including expected REC prices and rebates, do a "back-of-the-envelope" calculation to see if the economics make sense.

Determine whether an environmental-impact assessment is going to be necessary, particularly as it relates to ground-mounted systems. Finally, address both safety and security issues with the appropriate internal parties to make sure these two areas do not present barriers later in the process.

\section{Step 2: Select Developer Through Competitive Process}

Federal agencies must comply with the Federal Regulation Acquisition (FAR) rules of procurement. If the site is big enough (can support a project of a minimum size of approximately $1 \mathrm{MW}$ ), consider releasing a request for qualifications (RFQ) followed up with a request for proposals (RFP) after the number of potential vendors has been narrowed. If the site only can support a smaller system, then developers might not respond to a formal RFP and perhaps should be contacted individually to gauge potential interest.

The potential developers will request the information developed in Step 1 so that they can make their own initial assessment of the feasibility of the project. Additional information that the developers could require include the utility's interconnection requirements, confirmation of access to the site, and information on the soil if the system is a ground-mounted one.

\section{Step 3: Site Assessment and Term-Sheet Development}

Based on the preliminary information provided by the federal agency and its own research, the developer conducts a high-level site assessment that includes electricity needs, solar generation potential, financial incentives, and engineering issues. This is an initial proposal to determine the feasibility of the project. Based on this assessment, the developer drafts a term sheet that includes the estimated output of a solar project, the price of electricity, and contract's term. If a tentative agreement on the term sheet is made, then the project can move forward. 


\section{Step 4: Contract Development}

The contracts are negotiated and signed. There are multiple contracts involved in the PPA process. A PPA agreement is made between the public entity and the PPA provider. There also could be a separate agreement between these same two parties, and related to the easement or lease which provides access to the property. The PPA provider and the utility also can sign a separate agreement for the solar RECs.

\section{Step 5: Rebate Processing}

If the state or utility offers incentives, then the application requesting them should be filed no later than at this point in the process. Note that in some states, there might be a limited window of time during which incentives are awarded to qualifying projects - for example, New York holds auctions. Depending on the state, in some cases the rebate could go to the host who must endorse it over to the PPA provider. The utility pays the PPA provider directly for the RECs.

\section{Step 6: Project Design and Financing}

A detailed project engineering analysis is performed and the system is designed — based on more precise measurements that are specific to the site. Using the term sheet and the intent to enter into a contract, project financing also is arranged.

\section{Step 7: Permitting}

Local regulatory agencies require appropriate documentation to issue building permits. It is useful to determine whether there is a backlog of permits and the date that the project must be in the queue for this step to be completed (aiming for approximately the same date the contract is signed).

\section{Step 8: Procurement, Construction, and Commissioning}

The developer arranges for the components and equipment to be supplied to the site, at which point the system is installed and tested. At commissioning there is a final confirmation test to prove system performance to the utility, so that the utility will interconnect the system and allow system activation.

\section{Step 9: Monitoring and Maintenance}

The host must allow the developer and the owner to access the site for maintenance activities during the entire life of the project. The system is monitored through a combination of automatic, remote readings of power performance and other indicators, and also can include manual, on-site readings of performance indicators. If there an anomaly is detected, then the system is accessed on the host's site for any needed repairs and equipment replacement.

\section{Important Federal PPA Provisions for Agreements Involving WAPA}

In addition to the steps described for how to execute a third-party ownership/PPA, there are some specific contract provisions important for WAPA involvement as a contractual intermediary. Federal agencies should consider these provisions before issuing an RFP. Including such provisions on how to distribute the project's risks in the RFP will help the agency secure the most promising and economical responses.

The information below mostly comes from a January 17, 2008, "webinar" presentation by Melanie Reed, RMR Contracts and Energy Services Manager at WAPA, titled "Renewable 
Energy Generation on Federal Sites." It is supplemented with information from the discussion during the webinar.

Term:

- Generally, needs to be long-term to attract project financing

- The longer term also could provide a financial benefit to the government

- Initial term of 20 years is standard, with renewal options

Payment to vendor:

- Federal agency pays the vendor directly for the power purchase

- Eliminates WAPA as the middleman, thus reducing administrative costs

- Failure to perform

- Holds the vendor accountable for its obligations

- Example: If the generator fails during the term of the contract

- Generally does NOT include paying a penalty for failure to build a system by a specific date; it is more acceptable to the developer to include milestones and track them regularly

- Can negotiate accountability if milestones are not met

- Hold the federal agency accountable for its obligations

- Example: Payment (contingent on appropriations), site lease, etc.

- Financiers do not like the appropriations contingency, but it is part of working with the federal government

○ Off-ramp provisions

- The more off-ramps a federal agency has, the more likely the contract price will be higher (particularly if there are monetary penalties)

○ Off-ramp examples

- Vendor is unable to obtain a site easement with the federal government

- Vendor is unable to obtain an interconnection agreement with the local utility

- Vendor cannot secure REC buyer

- Vendor cannot obtain financing

- Important to describe situations in which the project would be unable move forward

Federal agency's cost for the power:

- Fixed kilowatt-hour rate over the term of the contract, or an escalating rate

○ Monthly bill from vendor

- Early termination penalties

- Provisions that could transfer project ownership to the federal agency

- Provisions that would increase cost during the life of the contract if market conditions change

- Recommendation: Flesh-out the potential costs and risks and perform a cost/risk analysis

Metering and communications:

- Required by local utility, REC purchaser, and WAPA

- Provisions vary depending on requirements

- Minimum delivery requirements (specify them in the RFP, to be clear) 


\section{Appendix D. Critical Steps Using WAPA as a Contractual Intermediary}

Information in this section mostly is drawn from a January 17, 2008 "webinar" presentation by Melanie Reed, the RMR Contracts and Energy Services Manager at WAPA, titled "Renewable Energy Generation on Federal Sites." It is supplemented with information from the discussion during the webinar.

Generally, the requesting agency must manage the process. The WAPA is willing to review and provide input on requests for information (RFI) or requests for proposals, but it will not write the RFI/RFP and it will not select the winning vendor. WAPA does not have the resources to manage the vendor; it will be involved, but it will not manage the process. Also, WAPA prefers to allocate its resources to commit a little bit of time to each project over 6 months, for example, rather than being $100 \%$ committed to a single project for 2 months.

\section{Contracts Needed}

Putting together contract templates can be difficult for a number of reasons, including capturing the unique requirements of each vendor and financier. Because there can be surprises along the way, it is important to be able to understand and articulate the federal agency's requirements upfront, and to be as clear as possible in the RFI/RFP. For a typical federal project that uses WAPA as the contracting intermediary, the following contracts are needed:

WAPA and federal agency

- Statement of interest (SI) to initiate the process

- Interagency agreement (IA) to purchase power (and RECs, if applicable) through WAPA on a pass-through cost basis; or

- Support energy or supplemental energy provision of the federal agency's firm electric service contract with WAPA

WAPA and vendor

- Contract for WAPA to purchase the power for the federal agency (might or might not include RECs)

Federal agency and vendor

- Site lease or easement agreement

$\circ$ Environmental assessment is required and the results should be in the lease/easement

- Could require involvement of other federal agencies if there is a separate manager (such as the Army Corps of Engineers, GSA, etc.- - the more entities are involved, the longer process likely will take)

Federal agency and local utility

- Coordinate and receive approval for interconnection of the project from the local utility serving the federal agency

O Usually can be done under existing contracts for firm electric service

Is helped by net metering laws, where applicable

Vendor and REC purchaser, if applicable

Vendor and financier 
Note that neither WAPA nor the federal agency is involved in the last two scenarios, but the terms of these agreements will impact the PPA price, so these agreements are of interest.

\section{Important Issues and Lessons Learned for Contracts Involving WAPA}

Non-disclosure agreement (NDA) from vendor

- WAPA and the federal agency could be asked to sign an NDA. To date, WAPA has not done so.

Metering and communications

- Coordinating, installing, and implementing metering and communication agreements have proven to be more complicated and difficult than expected.

- In most cases, WAPA requires real-time data. Capturing this data takes coordination among the vendor, WAPA, and the local utility.

\section{Contract terms}

- Include as many requirements as possible in the RFP before selecting a vendor.

- If requirements are not included in the RFP, be sure to discuss them as soon as possible upon selecting a vendor.

\section{WAPA Contact}

Randy Manion, Renewable Resource Program Manager, Western Area Power Administration (720) 962-7423, Manion@wapa.gov. 


\section{Appendix E. Critical Steps for Assessing Federal Project Potential}

The Federal Energy Management Program team at NREL has developed a methodology for assessing the project potential at federal sites, based on several years of technical assistance experience. This methodology is briefly outlined below to provide federal agencies with basic recommendations on how to screen for the most cost-effective renewable energy projects; a few agency examples are also explored. Additional information can be obtained by securing technical assistance from the NREL FEMP team, which works to support federal agencies in meeting renewable energy and energy efficiency goals and mandates.

\section{Step 1: The Project Screening Process}

Before deciding to deploy solar or other renewable technologies on-site, federal agencies should first assess which of sites presents the best opportunity and which renewable technologies are most appropriate. As on-site renewable energy technologies are evaluated, the sites(s) also should be evaluated for appropriate energy-efficiency measures that can reduce the project's overall cost.

NREL has developed a four-step process when evaluating whether to move forward with a renewable energy project at a federal site. At potential sites of interest, an agency should:

- Screen for highest potential renewable energy technologies and select the most promising locations;

- Develop in-depth economic and engineering feasibility analyses for sites selected through screening (Step 1);

- Proceed with procurement of those projects that pass the feasibility test (Step 2); and

- Construct and implement the project.

Following this four-step process of evaluation, NREL also encourages that the sites be monitored to ensure that performance expectations are being met. Lastly, NREL recommends that these projects be publicized. Communicating the experiences gained through individual projects is a valuable tool in both promoting and educating other departments on renewable energy and energy-efficiency opportunities.

The NREL FEMP team has helped numerous agencies and private entities consider and execute all of the steps listed above. Much of the assistance has come in the form of technical aid and recommendations for the screening phase of potential projects. Determining whether a federal facility is a potential candidate for renewable energy generation can be overwhelming for on-site personnel that lack expertise in this area. As a result, NREL has created a screening process to evaluate federal facilities for on-site renewable energy generation potential. The screening process is a structured approach that examines key factors to make an initial assessment. If this initial assessment is positive, then a more in-depth analysis is conducted before a decision is made to move forward with an on-site renewable project.

The cost-effectiveness for renewable energy at various sites is evaluated using the following three criteria: 
- Current energy rates

- Availability of financial incentives

- Renewable resource.

Ideally, a proposed project would be supported by high regional energy rates, strong financial incentives, and a good renewable resource. Energy rates are evaluated differently depending on whether the proposed project would be on an existing site, a new site, or an off-grid site The agency also must consider its current cost of power versus future project costs, the cost to add new power (including the need to extend the grid), the cost of transporting fuel, and any environmental consequences or risks associated with potential fuel use or fuel spills. [140] Also important are the financial incentives available for many renewable energy technologies and which are accessible to federal agencies (described above). State, local, federal, and utility incentives are vital components to understanding the feasibility and opportunities of an individual project. Finally, the quality of renewable energy resources at each location under consideration must be analyzed during the screening assessment. Even if a project is in a location that does not have high electricity rates or great renewable resources, if the financial incentives are great enough, the renewable project still might be financially viable.

\section{Step 2: Tools Available for Screening}

Reviewing these three criteria is challenging, particularly when considering multiple renewable energy technologies for numerous sites. Federal agencies, however, have access to a variety of Web resources that can help with quick assessments during the screening phase. The following links are to Web sites that provide additional software tools that can aid agencies in developing a general overview of proposed projects at designated renewable energy sites. Note that this list is not comprehensive and does not include all screening tools available.

\section{Federal Renewable Energy Screening Assistant}

The National Renewable Energy Laboratory developed the Federal Renewable Energy Screening Assistant (FRESA) as a basic renewable energy screening tool. At the building scale, FRESA can assess photovoltaics, solar hot water heating, and wind energy; at the facility scale, it can evaluate photovoltaics and wind energy. [141] This tool is currently in development, and a beta version can be accessed at http://apps2.eere.energy.gov/femp/fresa/.

\section{Renewable Energy Optimization Tool}

To identify the combination of renewable energy measures that minimizes life-cycle cost at a site, NREL has been providing a service called Renewable Energy Optimization. An effort to produce a software tool is underway and, once complete, it will be available on the NREL

Web site.

\section{Database of State Incentives for Renewables and Efficiency (DSIRE)}

DSIRE is a Web-based, searchable database of renewable energy and energy efficiency policies and financial incentives that are available at the state, local, utility, and federal level. [142] It can be searched to target those incentives for which federal agencies are specifically available, and can be found at http://www.dsireusa.org/. 


\section{PVWatts}

PVWatts was created through NREL's Renewable Resource Data Center (RReDC). PVWatts was developed to aid non-experts in estimating the performance of grid-connected PV systems within the United States and its territories. [142] It is best used for standard PV technologies and not thin-film PV and can be found at http://www.nrel.gov/rredc/pvwatts.

\section{Renewable Resource Maps}

NREL has a wide variety of renewable energy resource maps that can aid agencies in analyzing and determining where the greatest renewable energy resources exist. In addition to national maps that show an overview by technology, NREL constantly is refining detailed, technologyspecific maps by U.S. state that include significant county-level detail. Available maps are on the NREL Web site at http://www.nrel.gov/gis/maps.html.

For high-cost technologies like solar, it is important to remember that areas with excellent resources might not have adequate incentives to support on-site development of renewable generation. Conversely, areas with poor resources might have incentives great enough to make the economics of renewable energy projects work. Each location must be evaluated separately to concurrently examine base electricity rates, incentives, and resources.

\section{Renewable Energy Technology Screen (RETScreen)}

RETScreen is an international, free software tool that can be used to "evaluate the energy production and savings, costs, emission reductions, financial viability and risk for various types of Renewable-energy and Energy-efficient Technologies (RETs).”[143]

http://www.retscreen.net/.

\section{Step 3: Assessing the Information Gathered}

In ideal situations, detailed information for each of the assessment criteria is obtained. The screening team, however, often must make do with much less information and therefore makes assumptions as necessary which will need to be validated if a project moves forward. The greater the detail provided, the more valuable the screening assessment.

Various projects should weight the significance of the three criteria differently. For instance, the cost-effectiveness of a PV project likely would be more dependent on financial incentives than on resource availability. The reason for this not only is that solar generally is more expensive than other renewable energy options, but also because it is an abundant resource throughout most of the country and is therefore less constrained geographically.

\section{Step 4: Additional Information Might Be Required}

Lastly, additional information could be needed to comply with specific laws before a project can be sited. Examples include compliance with the National Environmental Policy Act (NEPA), discussed in more detail below. Other laws, like the National Historic Preservation Act (NHPA) also might need to be addressed.

Under the NEPA, when federal agencies propose any "major federal action" a detailed environmental review of the action and its alternatives are required to determine the overall environmental, economic, and social impacts. Major federal actions can include the building of new buildings, major modifications to an existing building, or any significant construction 
occurring on federal land, such as a PV array. For a PV system, the level of detail of the review depends on the scale of the activity. An environmental assessment (EA) is prepared to determine whether a significant impact will occur and, if the answer is "no," then a finding of no significant impact (FONSI) is prepared. If the answer is "yes," or if a project is already suspected to have an impact, then the federal agency prepares more comprehensive environmental impact statement (EIS). During the process of developing an EIS, the public, other federal agencies, and interested stakeholders can provide comments. EPA carries out the operational duties associated with the administrative aspects of the EIS filing process. The Council on Environmental Quality (CEQ) requires all federal agencies to assess environmental impacts of major federal actions including all actions which are the subject of an EIS.

If a federal agency is preparing to perform the same federal action several times on one or more than one site, then the agency can prepare a programmatic EIS (PEIS). The PEIS examines the details of the environmental impact of the activity as it relates to all potential sites of the activity. This provides an umbrella mechanism for an activity that will be repeated on several sites. When a specific project moves forward, an EA can be prepared to examine the site-specific aspects of the project, and the bulk of the information needed be captured in the PEIS. Any site-specific concerns could require evaluation with a site-specific EIS for those specific aspects not covered in the PEIS.

\section{Example: BLM Solar Programmatic EIS}

The Bureau of Land Management and the Department of Energy have teamed together to initiate a joint PEIS for development of solar in six western states: Arizona, California, Colorado, Nevada, New Mexico, and Utah. [144] The joint PEIS will evaluate solar energy development on BLM lands in these six states and will examine alternative management strategies. The goal of the overall study is to identify how to mitigate potential impacts of developing solar energy projects. As specific projects are developed, a site-specific environmental analysis can be conducted to identify potential site-specific impacts and ways to mitigate them.

As work on the PEIS is performed, BLM concurrently will examine project-specific details of the solar projects that have already applied for rights-of-way for project development. To date, BLM has received more than 130 such applications for land covering almost 1 million acres and with the potential to generate 70 million kilowatts of electricity (enough to power 20 million average U.S. homes). The BLM expects to be able to complete the PEIS before being able to review the 130 land applications, at which point remaining projects can shift over to use the PEIS process for their development. Federal agencies can keep up to date on PEIS development at http://solareis.anl.gov.

Once the PEIS is in place it establishes the process for future solar development. Any additional applications received as the PEIS is being developed are evaluated after the PEIS is in place. To promote additional solar development, the BLM can establish a competitive process to attract qualified companies to develop solar quickly and effectively.

\section{Step 5: Detailed Feasibility Studies}

After applying the screening process described above, the result is a list of the most viable renewable energy projects available at a federal agency's sites. The second step of this process involves a more detailed look at the economic and engineering feasibility of potential projects. 
As with the initial screening, there are many software tools that can aid with these analyses, a few of which are described below.

\section{HOMER}

The National Renewable Energy Laboratory developed HOMER, which is an optimization tool that accounts for economic and technical feasibility of both off-grid (remote and standalone) and grid-connected, distributed power systems.[145] The software is designed to help the user consider a great number of technology options, range of technology costs, and variability of energy resources, all of which typically can make distributed technology choices difficult. HOMER's optimization and sensitivity analysis algorithms make it easier to evaluate the many possible system configurations. [146] The HOMER software is available for use at https://analysis.nrel.gov/homer/.

\section{Energy-10}

Another in-depth software tool is the Sustainable Building Energy Council's (SBIC) Energy-10. This simulation tool analyzes up to a dozen sustainable design strategies, including renewable energy technologies, for homes and buildings. [147] The tool is available at http://www.sbicouncil.org/displaycommon.cfm?an=1\&subarticlenbr=112.

In addition to these elaborate tools, an understanding of financing options (as discussed in this report) becomes vital to decisions that can make or break prospective projects.

\section{Two Examples: Federal Project Assessments}

NREL has conducted large-scale screenings of renewable energy project potential for several federal agencies. Two screening examples are provided below to further explain how to assess project potential. The examples include project assessments for the Smithsonian Institution National Zoological Park, and for 88 Job Corps Centers for the Department of Labor.

\section{Smithsonian Institution National Zoological Park-Two Locations}

The National Renewable Energy Laboratory worked with the Smithsonian Institution National Zoological Park on an economic analysis to identify the best solution for becoming a net-zero facility, whereby $100 \%$ of the Zoo's annual energy consumption is met with renewable sources. The project took into consideration the energy needs of both the National Zoo in Washington, DC, and the 4,600-acre Conservation Research Center in Front Royal, Virginia. NREL used an early version of the Renewable Energy Optimization tool to assess which combination of renewable energy technologies would produce the minimal life-cycle cost. [148] Although previous screening efforts have evaluated each renewable energy technology independently, this example highlights the ability to analyze the interactions among multiple technologies at a site.

As described, the process of optimizing available EE and RE technologies utilizes three main criteria: local resources, utility rates, and incentives. Such initial information usually is readily available, which reduces time and cost associated with detailed analyses. The results from the initial analysis provide an efficient starting point for more detailed assessments. Table E-1 presents the initial results of an analysis of renewable energy opportunities for the National Zoological Park's primary facilities. As explained by Andy Walker, the NREL staff member that conducted the assessment, "results indicate that renewable energy measures could be integrated directly into 
buildings at both sites (PV, solar water heating, solar ventilation air preheating) but that central plant use of renewables (wind and biomass) would be needed to meet the zero energy goal." [149]

Table E-1. Optimal Sizes of Each Technology in Zoo Example

\begin{tabular}{|c|c|c|c|}
\hline & $\begin{array}{l}\text { National. } \\
\text { Zoological Park, } \\
\text { Washington, DC }\end{array}$ & $\begin{array}{l}\text { Conservation. } \\
\text { Research } \\
\text { Center, VA }\end{array}$ & Total \\
\hline Photovoltaics Size (kW) & 638 & 224 & 862 \\
\hline Wind Capacity (kW) & 0 & 14,500 & 14,500 \\
\hline Solar Vent Preheat Area $\left(\mathrm{ft}^{2}\right)$ & 10,655 & 8,075 & 18,730 \\
\hline Solar Water Heating Area $\left(\mathrm{ft}^{2}\right)$ & 7,535 & 2,180 & 9,715 \\
\hline Biomass Gasifier Size (M Btu/h) & 10,996 & 0.000 & 10,996 \\
\hline Biomass Cogeneration Size (kW) & 1,168 & 0 & 1,168 \\
\hline Anaerobic Digester Size $\left(\mathrm{ft}^{3}\right)$ & 3,723 & 459 & 4,182 \\
\hline Anaerobic Digester Cogeneration Size (kW) & 12 & 0 & 12 \\
\hline Daylight Aperture (Skylight) Area $\left(\mathrm{ft}^{2}\right)$ & 21,221 & 6,476 & 27,697 \\
\hline \multicolumn{4}{|c|}{$\begin{array}{l}\text { Source: Walker, A. "Renewable Energy Planning: Multiparametric Cost Optimization." Presented at } \\
\text { Solar 2008, American Solar Energy Society (ASES), San Diego, CA, May 3-8, } 2008 . \\
\text { http://www.nrel.gov/docs/fy08osti/42921.pdf. Accessed June 11, 2009. }\end{array}$} \\
\hline
\end{tabular}

This optimized portfolio of RE technologies resulted in a net cost of about \$22 million more than the business-as-usual cost of purchasing electricity and natural gas from the utility. The life-cycle cost of deploying the portfolio of RE technologies is calculated by adding the total up-front capital cost to any annual costs (e.g., maintenance, fuel, payments to utility, production incentives, cash flows), and discounting them back to their present value. [150] Details of the cost analysis are shown below in Table E-2. Although the life-cycle costs of the RE portfolioeven when fully optimized - were significantly more than the business-as-usual costs, several key factors were not evaluated quantitatively. These factors include potential benefits from emissions reductions, educational value, as well as the significance in achieving the net-zero goal. 
Table E-2. Life-Cycle Cost of Business-as-Usual Case as Compared to the Zero-Energy Zoo Case

\begin{tabular}{|l|r|c|}
\hline Name & $\begin{array}{c}\text { Business as } \\
\text { Usual Life Cycle } \\
\text { Cost }(\$)\end{array}$ & $\begin{array}{c}\text { RE Case Life } \\
\text { Cycle Cost } \\
(\$)\end{array}$ \\
\hline Initial Cost & $\$ 0$ & $\$ 45,858,421$ \\
\hline $\begin{array}{l}\text { Operations and Maintenance } \\
\text { Cost }\end{array}$ & $\$ 0$ & $\$ 13,135,266$ \\
\hline Biomass Fuel Cost & $\$ 0$ & $\$ 5,762,545$ \\
\hline Gas Cost & $\$ 17,323,188$ & $\$ 5,713,053$ \\
\hline Electric Cost & $\$ 0$ & $-\$ 2,887,806$ \\
\hline Production Incentives & $\$ 52,237,272$ & $\$ 74,777,968$ \\
\hline Total & $\begin{array}{l}\text { Source: Walker, A. "Renewable Energy Planning: Multiparametric Cost } \\
\text { Optimization." Presented at Solar 2008, American Solar Energy Society } \\
\text { (ASES), San Diego, CA, May 3-8, 2008. } \\
\text { http://www.nrel.gov/docs/fy08osti/42921.pdf. Accessed June 10, 2009. }\end{array}$ \\
\hline
\end{tabular}

\section{Job Corps Centers of the Department of Labor-88 Locations}

At the request of the Department of Labor, NREL carried out a renewable energy screening for 88 Job Corps Centers across the United States and Puerto Rico. [151] To conduct the screening, the different Centers provided site-specific information, including:

- Longitude and latitude;

- Number of users;

- Square footage of buildings;

- Electricity and fuel usage; and

- Electricity and fuel costs.

Using NREL GIS solar resource maps, NREL screened sites for the potential application of PV, solar hot water heating, and solar ventilation air preheating. For each site, NREL calculated the maximum resource potential per technology, a lifecycle savings-to-investment ratio (SIR) and a simple payback ratio. The most promising sites were then ranked according to their SIR ratios. The table below shows the four sites with an SIR of greater than 1 for potential PV projects.

Table E-3. Cost-Effective Opportunities for Photovoltaics at Job Corps Centers

\begin{tabular}{|l|c|c|c|c|c|}
\hline $\begin{array}{l}\text { Center } \\
\text { Name }\end{array}$ & State & $\begin{array}{c}\text { PV Annual Energy } \\
\text { Delivery per kW of } \\
\text { PV (kWh/year/kW) }\end{array}$ & $\begin{array}{c}\text { PV Installed Cost per } \\
\text { kW of PV with } \\
\text { Incentives }\end{array}$ & $\begin{array}{c}\text { PV Annual Energy } \\
\text { Cost Savings per } \\
\text { kW of PV (\$/year) }\end{array}$ & $\begin{array}{c}\text { Grid } \\
\text { Connected } \\
\text { PV SIR }\end{array}$ \\
\hline Edison & NJ & 1,229 & 1,280 & 100 & 1.81 \\
\hline South Bronx & NY & 1,235 & 2,945 & 256 & 1.46 \\
\hline Los Angeles & CA & 1,517 & 2,600 & 178 & 1.13 \\
\hline San Diego & CA & 1,533 & 4,300 & 273 & 1.06 \\
\hline
\end{tabular}

Photovoltaics were evaluated at 88 locations. The SIR ranged from 0.22 to 3 . Table E-3 lists the best four sites. After NREL conducted these screenings it became the responsibility of the Department of Labor to determine how and whether it will act on the information provided. 
NREL can remain involved in the process to provide additional technical expertise or the agency could seek assistance elsewhere. If NREL is hired to remain involved, an interagency agreement will be executed. 


\section{Appendix F. History of Relevant Legislation and Executive Orders}

\section{Executive Order 13123 (superseded)}

In 1999, President Clinton signed EO 13123, which asked agencies to reduce overall federal building $\mathrm{CO}_{2}$ emissions to $30 \%$ of 1990 levels by 2010 . Section 202 set energy-efficiency goals for standard buildings to reduce their energy consumption per gross square foot $30 \%$ by 2005 and $35 \%$ by 2010 , relative to 1985 . Similarly, Section 203 set efficiency goals for energyintensive facilities to reduce energy consumption per gross square foot by $20 \%$ by 2005 and $25 \%$ by 2010 relative to 1990 consumption. [152] Section 204 of this EO also created a federal goal whereby each agency would "strive to expand the use of renewable energy within its facilities and in its activities by implementing renewable energy projects and by purchasing electricity from renewable energy sources." [153] In 2001, the U.S. Secretary of Energy issued guidance on the EO renewable energy goal that requested federal agencies obtain a minimum of $2.5 \%$ renewable electricity by $2005 .[154]^{49}$ The bulk of federal agencies was able to achieve this goal, and in 2005 renewables accounted for nearly $7 \%$ of total federal electricity consumed. [155] As described in Section 1.3, this EO was superseded by EO 13423.

\section{Energy Policy Act 2005}

Although EO 13123 resulted in renewable energy goals for the federal sector, the first piece of legislation that actually required renewable electricity was the Energy Policy Act 2005 (EPAct 2005). The mandate requires that the following percentages of renewable energy (compared to total electric energy consumed by the federal agency) must be met during each specific fiscal year: 3\% in FY 2007-2009; 5\% in FY 2010-2012; and 7.5\% in FY 2013 and thereafter. [156] Note that these renewable requirements are incremental to any state or local renewable energy mandates, such as RPS mandates. The term "renewable energy" in EPAct 2005 includes "electric energy generated from solar, wind, biomass, landfill gas, ocean (including tidal, wave, current, and thermal), geothermal, municipal solid waste, or new hydroelectric generation capacity achieved from increased efficiency or additions of new capacity at an existing hydroelectric project." [157]

In addition to renewable energy use requirements, EPAct 2005 created incentives for renewable energy to be produced and used on federal grounds. A bonus within section 203(c) allows renewable electricity to count doubly towards compliance if it is: Produced and used on-site at a federal facility; produced on federal lands and used at a federal facility; produced on Native American land and used in a federal facility; or the on-site electricity produced by a federal agency is sold to a third party, but the power purchase contract states that the federal agency retains ownership of all related RECs and non-energy attributes. [158] The bonus is in place to encourage federal agencies to pursue energy projects sited on federal or Native American land, such as PV. It should be noted that the federal agency must either retain or replace the RECs to be eligible for the bonus.

The EPAct 2005 also established mandatory energy reductions in federal buildings. It requires reductions in federal facility energy intensity by $2 \%$ per year beginning in FY 2006, up to a reduction of at least $20 \%$ by the end of FY 2015. Additionally, Section 204 granted the General

\footnotetext{
${ }^{49}$ This guidance fulfills the requirement for the U.S. Secretary of Energy to establish a federal renewable energy goal under section 503(b) of Executive Order 13123, and consistent with section 204.
} 
Services Administration the authority to establish a "photovoltaic energy commercialization program for the procurement and installation of photovoltaic solar electric systems in new and existing public buildings." [159] EPAct 2005 directs that the energy commercialization program be allocated \$50 million annually for PV systems in fiscal years 2006-2010, and that the PV evaluation program be allocated $\$ 10$ million annually during the same period. Both of these "sums shall remain available until expended." [160] Even though these sums were authorized, Congress has not actually appropriated funds for this program, so the program remains unfulfilled. The GSA supports federal agencies in a number of ways, including centrally owning and maintaining federal buildings and equipment, so GSA could play a key role in federal PV deployment if funds were appropriated.

\section{Executive Order 13423}

In January 2007, EO 13423 was signed by President George W. Bush, and completely revoked EO 13123 (among others). EO 13423, Section 2(b) established that (i) a federal agency should strive to have at least half of the statutorily required (by EPAct 2005) renewable energy consumed in a fiscal year come from new renewable sources, and (ii) to the extent feasible, the agency should try to implement renewable energy generation projects on agency property for agency use. [161]

Executive Order 13423 superseded and updated aspects of EO 13123 and also has several differences from EPAct 2005. It includes a goal that at least 50\% of renewables come from new generation resources, with new defined as projects in commercial operation on or after January 1, 1999. This replaced the definition in the guidance document for EO 13123, of on-line on or after 1990. Further, like the previous executive order, EO 13423 allows non-electric renewable energy, such as thermal, to count as a new renewable resource. Non-electric renewable energy, however, still cannot be used to meet the EPAct 2005 mandate. Additionally, EO 13423 set a goal for agencies to reduce GHG emissions through a reduction in energy intensity of $3 \%$ per year, or $30 \%$ by 2015 , which is faster than the $2 \%$ per year and $20 \%$ overall reduction required by EPAct 2005. [162] This percentage is based on reductions in energy consumption per gross square feet, and uses fiscal year 2003 as the baseline, as opposed to a 2006 baseline in EPAct 2005. [163]

\section{Energy Independence and Security Act of 2007}

The Energy Independence and Security Act of 2007 (EISA 2007) was signed into law in December of 2007 and updated or increased several efficiency and renewable energy requirements for federal agencies. The Act effectively codified into law the EO 13423 goal of reducing energy intensity by $3 \%$ per year to ultimately achieve at least a $30 \%$ reduction by 2015 . [164] Therefore, EISA 2007 replaces the EPAct 2005 mandate of $2 \%$ per year. As with the EO goal, EISA 2007 uses 2003 as the baseline year. The Act also requires federal energy managers to conduct a comprehensive energy evaluation for each facility at least once every 4 years. [165]

EISA 2007 has additional provisions that could influence PV development. In Section 433 of the Act ("Federal Building Energy Efficiency Performance Standards"), the DOE is directed to revise federal building standards so that the fossil energy use of new buildings (compared to 2003) be reduced as follows: [166]

- $55 \%$ by 2010

- $65 \%$ by 2015 
- $80 \%$ by 2020

- $90 \%$ by 2025

- $100 \%$ by 2030 .

EISA 2007 also redefines energy savings for ESPCs. Energy savings now also can include the sale or transfer of excess (above on-site use) electrical or thermal energy generated from renewable sources or cogeneration to utilities or non-federal users. [167] Further, EISA 2007 clarified the ability of agencies to combine federally appropriated funds with private financing, including ESPCs and UESCs, to make projects work. [168] See Section 5.4 for a full description of ESPCs. 


\section{Appendix G. Energy Intensity Reductions and Renewable Energy's Role}

In addition to increasing the total amount of renewable energy use, the federal government also is targeting energy intensity reductions. This section clarifies the eligibility of renewable energy purchases and on-site renewable generation that can be counted towards these energy intensity reduction requirements - both now and in the future.

Unbundled RECs, renewable energy purchases (energy and attributes together), and on-site renewable energy generation all have contributed in helping the federal government achieve reductions in energy intensity. The ability to use renewable energy and REC purchases, however, as well as large on-site generation toward energy intensity goals (and perhaps mandates) will be eliminated gradually going forward.

As mentioned in Section 1.3, EISA 2007 codified into law the EO 13423 requirement that federal agencies continue reducing the energy intensity of their buildings by $3 \%$ per year through FY 2015, to culminate in a 30\% reduction based on levels from FY 2003. Energy intensity is the ratio of energy consumption (electric and non-electric uses) to total building square footage. Thanks to a number of efforts, the federal sector successfully has decreased its energy intensity since the late 1980s. From 1985 to 2005, the federal government invested \$7.3 billion in energyefficiency measures. Of that, $\$ 4.2$ billion came in the form of direct appropriations, and $\$ 3.1$ billion through ESPCs and UESCs. [169] These substantial programs resulted in significant energy-efficiency savings across the federal government, including the DOD and DOE. Table G-1 shows recent energy intensity improvements.

Table G-1. Federal Building Energy Intensity (Btu Energy Use per Gross Square Foot)

\begin{tabular}{|l|c|c|c|c|}
\hline \multicolumn{1}{|c|}{ Agency } & $\begin{array}{c}\text { Gross Square } \\
\text { Footage }\end{array}$ & \multicolumn{3}{|c|}{ Energy Intensity (Btu / GSF) } \\
\hline & $\mathbf{2 0 0 6}$ & $\mathbf{2 0 0 3}$ & $\mathbf{2 0 0 6}$ & \% Change \\
\hline DOD & $1,887,637$ & 113,510 & 107,208 & $-5.6 \%$ \\
\hline DOE & 89,266 & 261,340 & 235,908 & $-9.7 \%$ \\
\hline All Other & $1,023,084$ & 122,652 & 114,269 & $-6.8 \%$ \\
\hline Total & $2,999,987$ & 121,264 & 113,446 & $-6.4 \%$ \\
\hline
\end{tabular}

Eligibility of most renewable projects to count toward energy intensity goals gradually is being phased out and will be eliminated by 2013. Currently, purchases of renewable energy and unbundled RECs, ${ }^{50}$ as well as on-site renewable energy generation, can be credited toward energy intensity reduction targets set by Executive Order 13423. As shown in Table G-2, as the energy intensity reductions ramp-up, the ability to use REC purchases and large-scale metered renewable energy systems towards energy intensity calculations is reduced. Per the 2007 Guidance for EPAct 2005 and EO 13423, the single exception is for "small on-site renewable generation projects that do not incur fuel costs, are un-metered, and are located on the customer side of a facility's energy meter." [170] Therefore, some federal agencies could choose behind-

\footnotetext{
${ }^{50}$ Renewable energy purchases include the purchase of RECs (or environmental attributes), or the purchase of RECs bundled together with electricity. It does not include electricity from a renewable generator, unless the associated attributes are attached.
} 
the-meter PV as one way to help meet energy intensity mandates (in addition to energyefficiency activities).

Table G-2. Renewable Energy Purchase Contributions Toward Meeting Energy Intensity Requirements

\begin{tabular}{|c|c|c|c|c|}
\hline $\begin{array}{l}\text { Fiscal } \\
\text { Year }\end{array}$ & $\begin{array}{l}\text { Energy } \\
\text { Reduction } \\
\text { Goal }\end{array}$ & $\begin{array}{l}\text { Max Contribution of RE } \\
\text { and REC Purchases } \\
\text { Toward Energy Goal }\end{array}$ & $\begin{array}{c}\text { Max Contribution of } \\
\text { Long-Term Renewable } \\
\text { Energy and REC } \\
\text { Purchases toward Energy } \\
\text { Goal }\end{array}$ & $\begin{array}{c}\text { Energy } \\
\text { Reduction } \\
\text { Goal of New } \\
\text { Buildings }\end{array}$ \\
\hline 2003 & Base Year & $\begin{array}{c}\text { RECs and purchases not } \\
\text { applied in Base Year }\end{array}$ & $\begin{array}{c}\text { RECs and purchases not } \\
\text { applied in Base Year }\end{array}$ & Base Year \\
\hline 2007 & $4 \%$ & No Limit & Not Applicable & \\
\hline 2008 & $9 \%$ & $5.4 \%$ & $7.2 \%$ & \\
\hline 2009 & $12 \%$ & $4.8 \%$ & $7.2 \%$ & \\
\hline 2010 & $15 \%$ & $3.0 \%$ & $6.0 \%$ & $55 \%$ \\
\hline 2011 & $18 \%$ & $1.8 \%$ & $3.6 \%$ & \\
\hline 2012 & $21 \%$ & $0.0 \%$ & $0.0 \%$ & \\
\hline 2013 & $24 \%$ & & & \\
\hline 2014 & $27 \%$ & & & \\
\hline 2015 & $30 \%$ & & & $65 \%$ \\
\hline 2020 & & & & $80 \%$ \\
\hline 2025 & & & & $90 \%$ \\
\hline 2030 & & & & $100 \%$ \\
\hline \multicolumn{5}{|c|}{$\begin{array}{l}\text { * The combined total of both regular and long-term renewable purchases may not contribute more than } \\
\text { the percentages shown in column } 4 \text { above. } \\
\text { Source: U.S. Department of Energy, Office of Energy Efficiency and Renewable Energy, Federal Energy } \\
\text { Management Program. "Annual Report to Congress on Federal Government Energy Management and } \\
\text { Conservation Programs, Fiscal Year 2005," pg. 15. http://www1.eere.energy.gov/femp/pdfs/annrep05.pdf. } \\
\text { Accessed June 11, 2009. }\end{array}$} \\
\hline
\end{tabular}

The success of the federal government in reducing the energy intensity of its buildings and facilities could create both opportunities and challenges for PV development. On the one hand, bundling together the costs of energy-efficiency measures with PV deployment has the potential of reducing the payback period for a PV system and therefore encouraging investment in PV. Conversely, if energy conservation measures (ECMs) have already been executed, the agency might have to look toward more expensive ECMs and there could be fewer "bundling" opportunities for PV projects. President Obama is further emphasizing energy efficiency with the announcement of plans to modernize $75 \%$ of federal buildings with energy-efficiency improvements with the goal of reducing the government's total energy bill by a third. [171] 


\section{Appendix H. Useful Reference Documents and Internet Resources}

BLM Solar Programmatic Environmental Impact Statement, http://solareis.anl.gov/index.cfm.

California Solar Initiative Handbook 2007,

http://www.gosolarcalifornia.ca.gov/documents/CSI_HANDBOOK.PDF.

Database of State Incentives for Renewables and Efficiency (DSIRE), http://www.dsireusa.org/.

Executive Order 13423. "Instructions for Implementing Executive Order 13423."

http://ofee.gov/eo/eo13423_instructions.pdf.

Federal Energy Management Program (FEMP) Financing Mechanisms, http://www1.eere.energy.gov/femp/financing/mechanisms.html.

FEMP ESPC and Super ESPC Training, http://www1.eere.energy.gov/femp/financing/superespcs training.html.

FEMP free technical services (without the need for an interagency agreement), http://www1.eere.energy.gov/femp/pdfs/espc toolkit.pdf.

Federal Renewable Energy Guidance, http://www1.eere.energy.gov/femp/pdfs/epact05 fedrenewenergyguid.pdf.

Interstate Renewable Energy Choices (IREC) and the North Carolina Solar Center. 2007. "Connecting to the Grid: A Guide to Distributed Generation Interconnect Issues." 5th Edition. http://www.irecusa.org/fileadmin/user_upload/ConnectDocs/IC_Guide.pdf.

Network for New Energy Choices, Interstate Renewable Energy Choices, Vote Solar Initiative and the Solar Alliance. 2007. "Freeing the Grid." Net Metering and Interconnection Report. http://www.newenergychoices.org/uploads/FreeingTheGrid2007 report.pdf.

Shirley, W. 2006. "Survey of Interconnection Rules.” The Regulatory Assistance Project. Prepared for the Florida Public Service Commission.

http://epa.gov/chp/documents/survey_interconnection_rules.pdf.

Solar Energy Industry Association. 2006. "Guide to Federal to Federal Tax Incentives for Solar Energy (Version 1.2).” http://www.seia.org/galleries/pdf/SEIA manual version 1.2.pdf. Accessed June 22, 2009. .

U.S. Environmental Protection Agency. 2004. "Guide to Purchasing Green Power," http://www.epa.gov/greenpower/documents/purchasing_guide_for_web.pdf.

Wiser, R. and Bolinger, M. 2006. "Federal Tax Incentives for PV: Potential Implications for Program Design.” Lawrence Berkeley National Laboratory.

http://repositories.cdlib.org/lbnl/LBNL-60193/. 


\section{Appendix I. Useful Contacts}

\section{U.S. Department of Energy-Federal Energy Management Program}

\section{Renewable Energy}

Anne Crawley

anne.crawley@ee.doe.gov

(202) 586-1505

Matt Gray

matthew.gray@ee.doe.gov

(202) 586-0067

\section{Energy Savings Performance Contracts}

Bill Raup

william.raup@ee.doe.gov

(202) 586-2214

\section{Utility Energy Service Contracts}

David McAndrew

david.mcandrew@ee.doe.gov

(202) 586-7722

\section{BLM Solar Programmatic Environmental Impact Statement}

Lisa Jorgensen

Department of Energy

Golden Field Office

lisa.jorgensen@go.doe.gov

Phone: (303) 275-4906

PEIS Information Center: http://solareis.anl.gov

National Renewable Energy Laboratory-Federal Energy Management Program Federal Energy Management Program Team Lead

Karen Thomas

karen.thomas@nrel.gov

(202) 488-2223

\section{Project Financing}

John Barnett

john.barnett@nrel.gov

(303) 384-7469

\section{Power Purchase Agreements}

Chandra Shah

Chandra.shah@nrel.gov

(303) 384-7557 
Initial Federal Agency Site Screening

Andy Walker

andy.walker@nrel.gov

(303) 384-7531

Alicen Kandt

alicen.kandt@nrel.gov

(303) 384-7518

\section{Energy-Savings Performance Contracts}

NREL can provide unbiased technical support for your project with a U.S. Department of Energy-approved energy services company (ESCO). Under an Energy-Savings Performance Contract (ESPC), U.S. federal agencies can contract with ESCOs to acquire private-sector investment for the capital costs of installing energy- and water-conservation equipment and renewable energy systems.

An ESCO guarantees a fixed amount of energy cost savings throughout the life of the contract (up to 25 years) and is paid by the agency from energy cost savings after the savings begin. Federal agencies retain the remainder of the energy cost savings.

Doug Dahle

douglas.dahle@nrel.gov

(303) 384-7513

John Barnett

john.barnett@nrel.gov

(303) 384-7469

\section{Utility Energy-Savings Contracts}

The Energy Policy Act of 1992 authorizes and encourages U.S. federal agencies to participate in utility incentive programs. Services provided by a utility for a project can range from auditing to installation and commissioning, including financing the entire project under a UESC. Utilities could cover the capital costs of the project in consideration of the energy savings the retrofits will produce. The net cost to the federal agency remains minimal, and the agency saves time and resources by using the "one-stop shopping" provided by the utility.

Karen Thomas

karen.thomas@nrel.gov

(202) 488-2223

Western Area Power Marketing Administration

Randy Manion

Renewable Resource Program Manager

Manion@wapa.gov

(720) 962-7423 


\section{Defense Energy Support Center}

For military agencies interested in doing separate third-party ownership/PPAs, or ESAs under ESPCs, the Defense Energy Support Center is preparing to execute these types of contracts. For more information, please contact the people listed below.

John Nelson

john.nelson@dla.mil

(703) 767-8523

Andrea Kincaid

Andrea.Kincaid@dla.mil

(703) 767-8669

\section{Nonprofit Organizations}

CESA-Clean Energy States Alliance, http://www.cleanenergystates.org/

Mark Sinclair

msinclair@cleanegroup.org

Community Office for Resource Efficiency

http://www.aspencore.org/

Gary Goodson

gary@aspencore.org

The Vote Solar Initiative

http://www.votesolar.org/

Adam Browning

abrowning@votesolar.org 


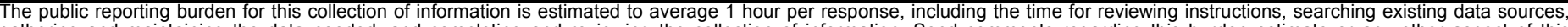

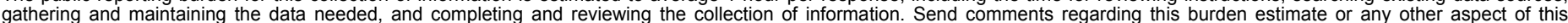

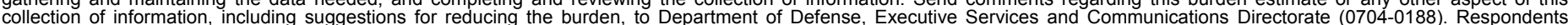

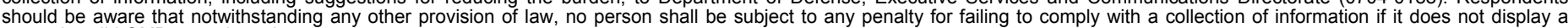

should be aware that notwithstanding

PLEASE DO NOT RETURN YOUR FORM TO THE ABOVE ORGANIZATION.
1. REPORT DATE (DD-MM-YYYY) July 2009
4. TITLE AND SUBTITLE
Solar Photovoltaic Financing: Deployment by Federal Government Agencies

3. DATES COVERED (From - To)

5a. CONTRACT NUMBER

DE-AC36-08-GO28308

5b. GRANT NUMBER

5c. PROGRAM ELEMENT NUMBER

5d. PROJECT NUMBER

NREL/TP-6A2-46397

5e. TASK NUMBER

PVB9.4210

5f. WORK UNIT NUMBER
7. PERFORMING ORGANIZATION NAME(S) AND ADDRESS(ES)

National Renewable Energy Laboratory

1617 Cole Blvd.

Golden, CO 80401-3393
8. PERFORMING ORGANIZATION REPORT NUMBER

NREL/TP-6A2-46397

9. SPONSORING/MONITORING AGENCY NAME(S) AND ADDRESS(ES)

10. SPONSOR/MONITOR'S ACRONYM(S) NREL

11. SPONSORING/MONITORING AGENCY REPORT NUMBER

12. DISTRIBUTION AVAILABILITY STATEMENT

National Technical Information Service

U.S. Department of Commerce

5285 Port Royal Road

Springfield, VA 22161

13. SUPPLEMENTARY NOTES

14. ABSTRACT (Maximum 200 Words)

The goal of this report is to examine how federal agencies can finance on-site PV projects. It explains state-level cash incentives available, the importance of solar renewable energy certificate revenues (in certain markets), existing financing structures, as well as innovative financing structures being used by federal agencies to deploy on-site PV. Specific examples from the DOD, DOE, and other federal agencies are highlighted to explain federal project financing in detail.

\section{SUBJECT TERMS}

Federal agencies; PV; available state-level cash incentives; solar renewable energy certificate revenues; SREC; financing structures; NREL; Karlynn Cory; Charles Coggeshall; Jason Coughlin; and Claire Kreycik.

\begin{tabular}{|l|l|l|l|l|}
\hline \multicolumn{1}{|l|}{ 16. SECURITY CLASSIFICATION OF: } & $\begin{array}{c}\text { 17. LIMITATION } \\
\text { OF ABSTRACT } \\
\text { U. REPORT } \\
\begin{array}{l}\text { Unclassified } \\
\text { b. ABSTRACT } \\
\text { Unclassified }\end{array}\end{array}$ & $\begin{array}{l}\text { c. THIS PAGE } \\
\text { Unclassified }\end{array}$ & $\begin{array}{c}\text { NUMBER } \\
\text { OF PAGES }\end{array}$ \\
\hline
\end{tabular}

9b. TELEPHONE NUMBER (Include area code) 